Portland State University

PDXScholar

TREC Final Reports

Transportation Research and Education Center

(TREC)

$12-2017$

\title{
Breaking Barriers to Bike Share: Insights from Bike Share Users
}

\author{
Nathan McNeil \\ Portland State University \\ Jennifer Dill \\ Portland State University, jdill@pdx.edu \\ John MacArthur \\ Portland State University, macarthur@pdx.edu \\ Joseph Broach \\ Portland State University, jbroach@pdx.edu
}

Follow this and additional works at: https://pdxscholar.library.pdx.edu/trec_reports

Part of the Transportation Commons, and the Urban Studies Commons Let us know how access to this document benefits you.

\section{Recommended Citation}

McNeil, Nathan, Jennifer Dill, John MacArthur, Joseph Broach. Breaking Barriers to Bike Share: Insights from Bike Share Users. NITC-RR-884c. Portland, OR: Transportation Research and Education Center (TREC), 2017. https://doi.org/10.15760/trec.191

This Report is brought to you for free and open access. It has been accepted for inclusion in TREC Final Reports by an authorized administrator of PDXScholar. Please contact us if we can make this document more accessible: pdxscholar@pdx.edu. 


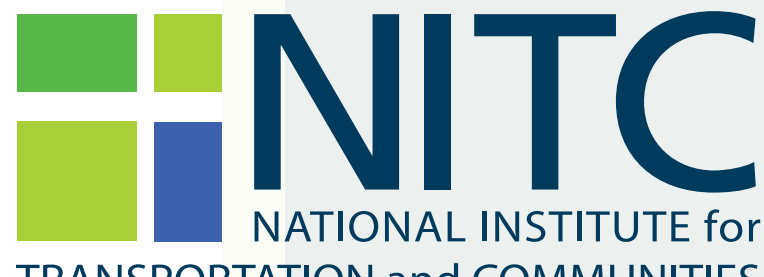

TRANSPORTATION and COMMUNITIES

FINAL REPORT

\section{Breaking Barriers to Bike Share: Insights from Bike Share Users}

NITC-RR-884c — December 2017

NITC is a U.S. Department of Transportation

national university transportation center.

=":! TREC 


\title{
Breaking Barriers to Bike Share: Insights from Bike Share Users
}

\author{
Final Report \\ NITC-RR-884c \\ By: \\ Nathan McNeil \\ Jennifer Dill \\ John MacArthur \\ Joseph Broach \\ Transportation Research and Education Center (TREC) \\ Portland State University
}

For:

National Institute for Transportation and Communities (NITC)

P.O. Box 751

Portland, OR 97207
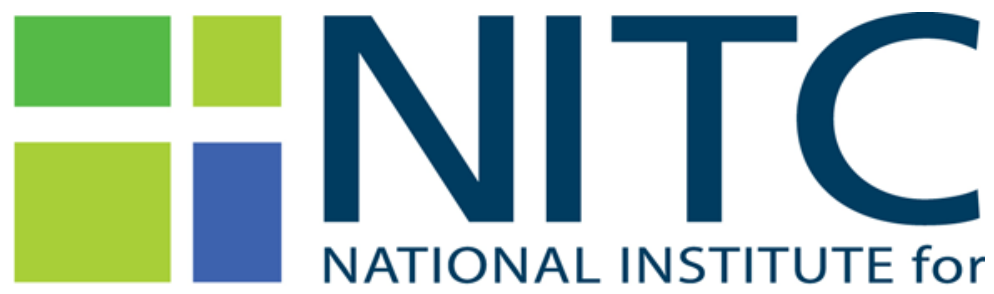

TRANSPORTATION and COMMUNITIES

December 2017 



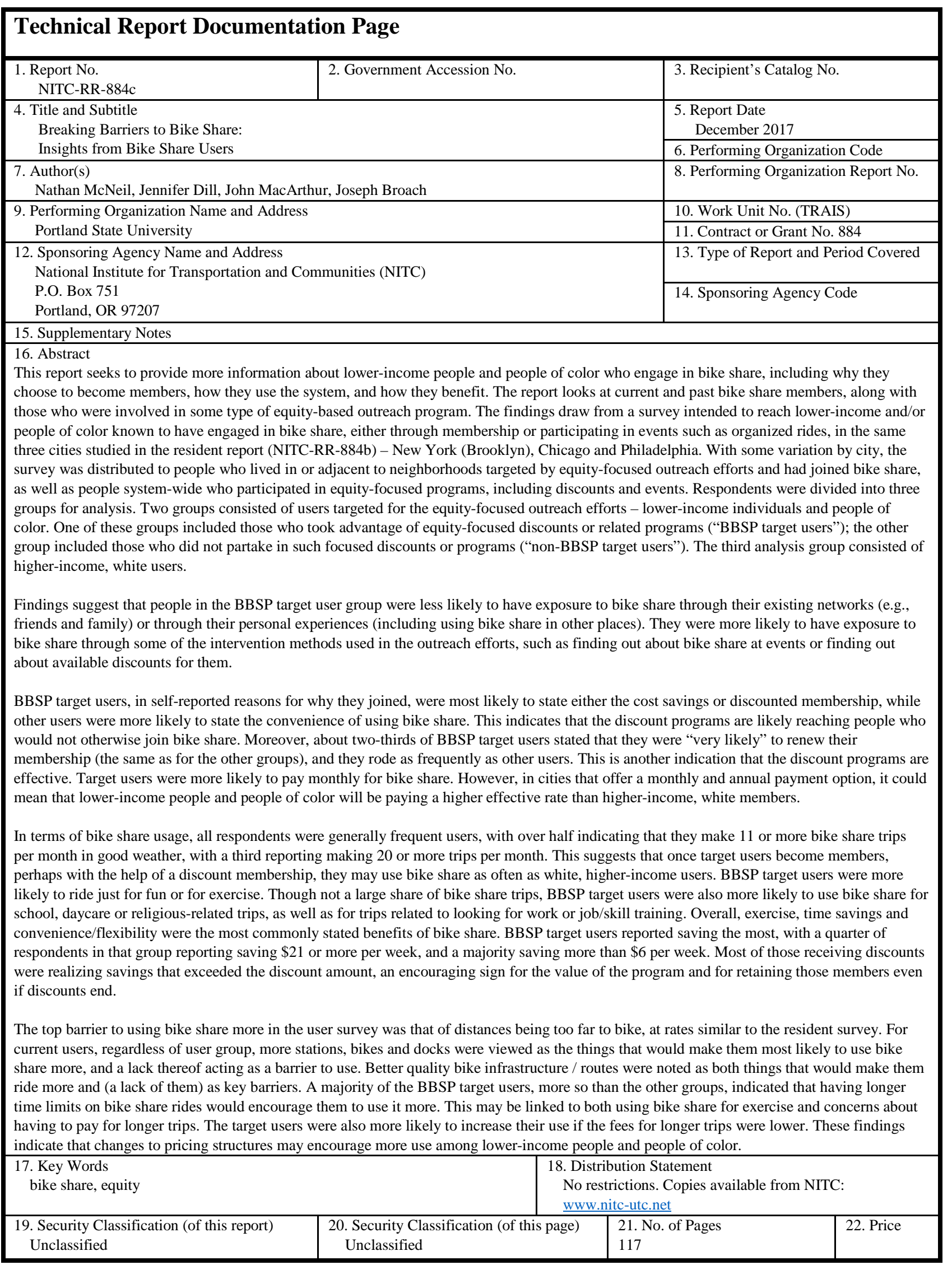





\section{ACKNOWLEDGEMENTS}

This research was funded by the Better Bike Share Partnership (BBSP), a collaboration made possible by The JPB Foundation; and the National Institute for Transportation and Communities (NITC) under grant number 884, a program of the Transportation Research and Education Center at Portland State University and a U.S. Department of Transportation University Transportation Center.

The research could not have been conducted without the significant participation of our city partners. These individuals shared their time and expertise, provided data, hosted our field visits, provided feedback on surveys and findings, and helped distribute surveys: Carniesha Kwashie, Aaron Ritz and Cara Ferrentino (City of Philadelphia); Claudia Setubal and Kiera Smalls (Bicycle Transit Systems); Katie Monroe and Waffiyyah Murray (Bicycle Coalition of Greater Philadelphia); Amanda Woodall and Sean Wiedel (Chicago Department of Transportation); Eliot Greenberger (Motivate); Ronnie Harris and Rebecca Noble (Go Bronzeville); Dan Black (Slow Roll Chicago); Tracey Capers, Verna Ademu-John, Joanna Lee Jacob and Aysu Kirac (Bedford Stuyvesant Restoration Corporation); Anne Krassner and William Bissell (Citi Bike); Dani Simons (Motivate); Beth Heyde (New York City Department of Transportation), Philip Noyes (New York City Department of Health and Mental Hygiene); along with Ted Graves and Kate Fillin-Yeh (NACTO), Zoe Kircos, Martha Roskowski and Jennifer Boldry (PeopleForBikes).

\section{DISCLAIMER}

The contents of this report reflect the views of the authors, who are solely responsible for the facts and the accuracy of the material and information presented herein. This document is disseminated under the sponsorship of the U.S. Department of Transportation University Transportation Centers Program in the interest of information exchange. The U.S. government assumes no liability for the contents or use thereof. The contents do not necessarily reflect the official views of the U.S. government. This report does not constitute a standard, specification, or regulation.

\section{RECOMMENDED CITATION}

McNeil, Nathan, Jennifer Dill, John MacArthur, Joseph Broach. Breaking Barriers to Bike Share: Insights from Bike Share Users. NITC-RR-884c. Portland, OR: Transportation Research and Education Center (TREC), 2017. 



\section{TABLE OF CONTENTS}

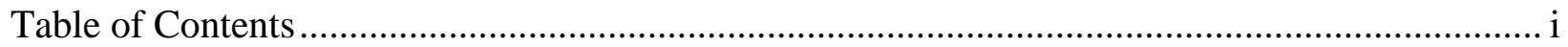

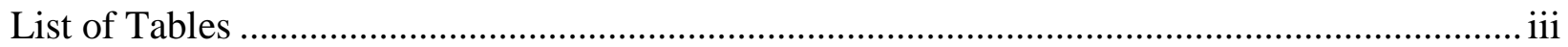

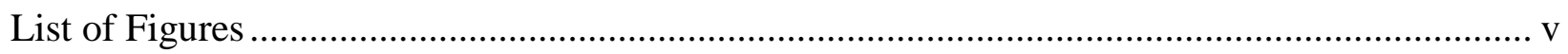

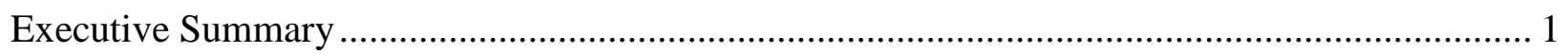

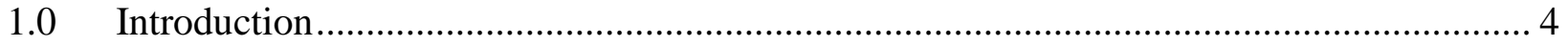

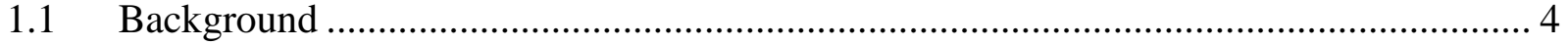

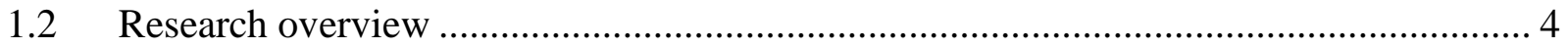

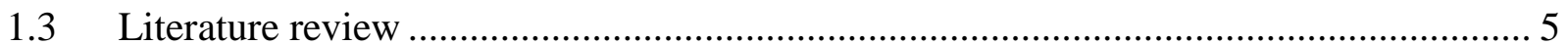

1.4 Bike share potential for underserved communities .................................................. 9

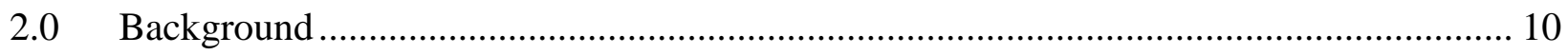

2.1 The Better Bike Share Partnership ..................................................................... 10

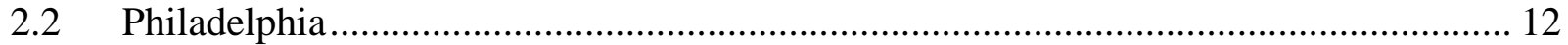

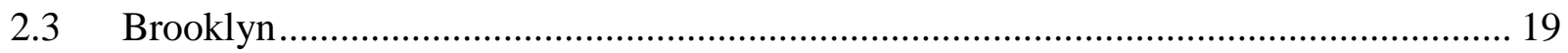

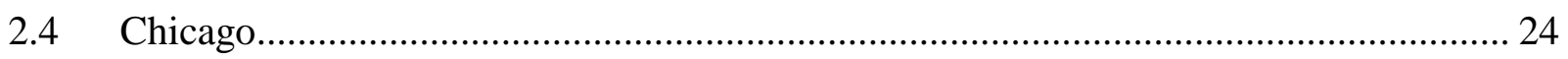

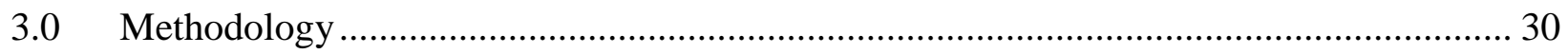

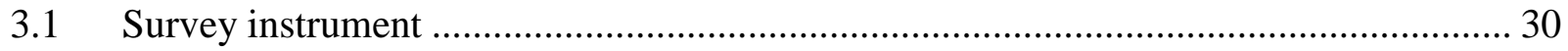

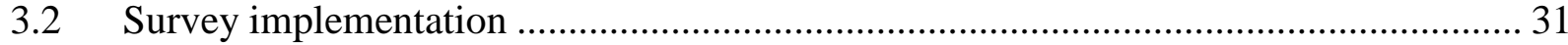

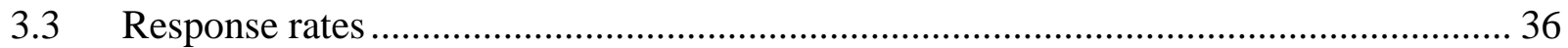

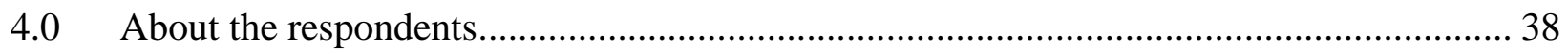

4.1 Demographic and basic bicycling information on respondents .............................. 38

4.2 Other respondent characteristics …..................................................................... 41

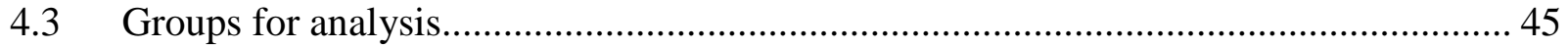

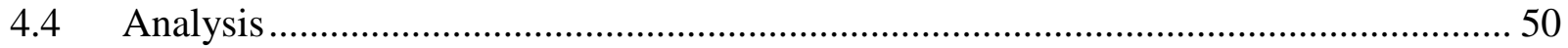

$5.0 \quad$ Bike share membership and experiences .................................................................. 51

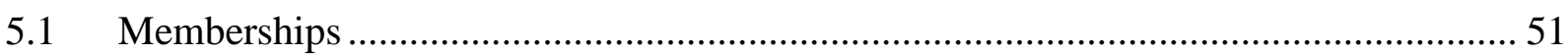

5.2 Exposure to information about bike share.......................................................... 56

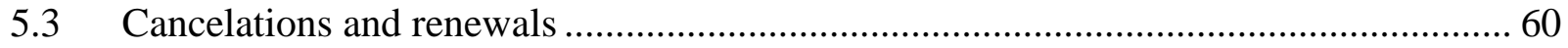

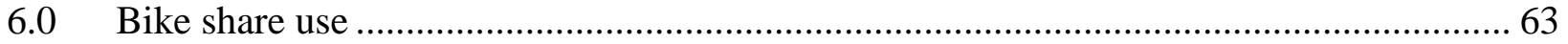

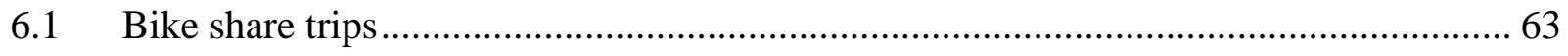




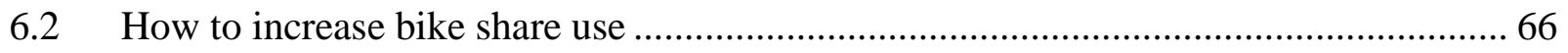

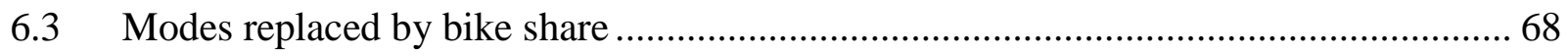

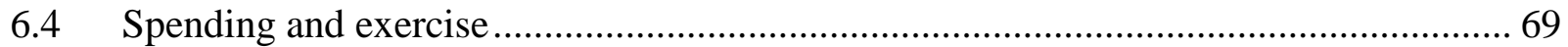

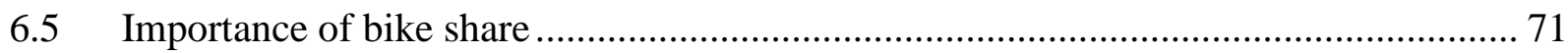

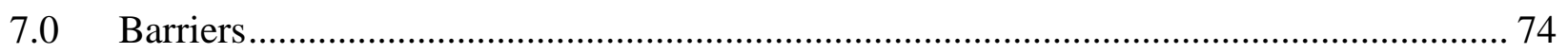

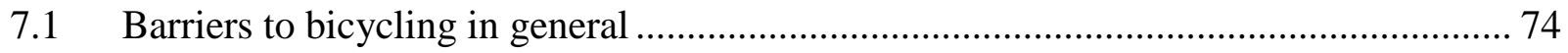

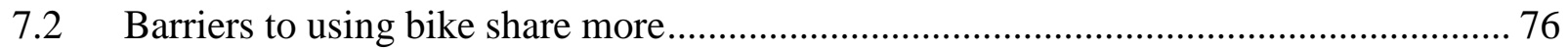

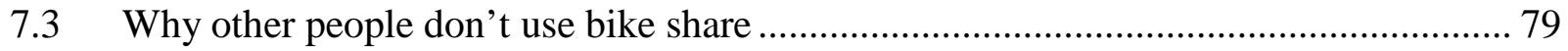

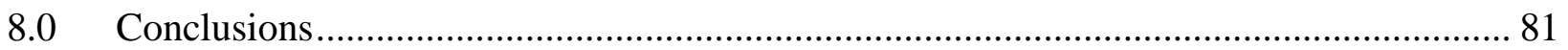

8.1 Sources of information differ for BBSP target users ............................................ 81

8.2 Cost considerations, including membership discounts, are important........................ 82

8.3 All users ride about the same amount, but for slightly different purposes................... 83

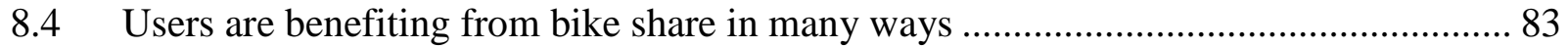

8.5 Are there barriers to these users using bike share more? ............................................ 84

8.6 Policy suggestions and future research directions................................................ 84

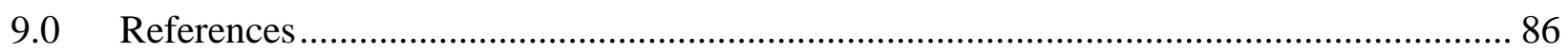

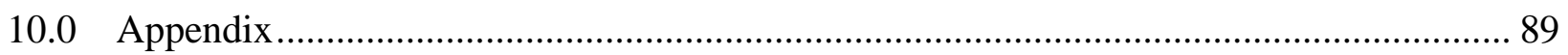




\section{LIST OF TABLES}

Table 2-1 Overview of BBSP context and program elements by study city ............................ 11

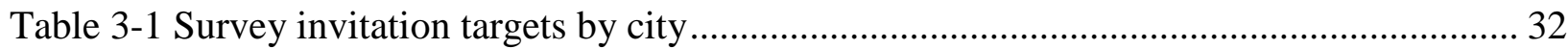

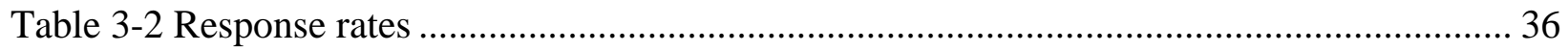

Table 3-3 Correspondence with target Zip Code areas....................................................... 37

Table 3-4 Correspondence with BBSP outreach study areas from resident survey ................... 37

Table 4-1 Brooklyn/New York City demographics ................................................................. 39

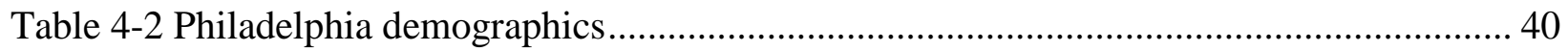

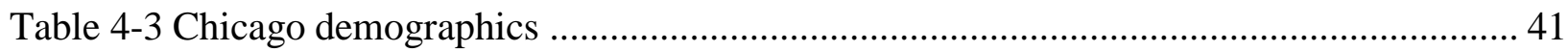

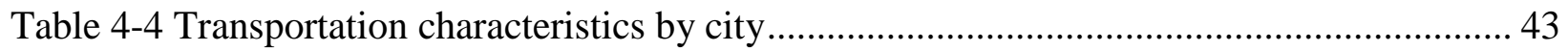

Table 4-5 Other social and demographic characteristics by city ........................................... 44

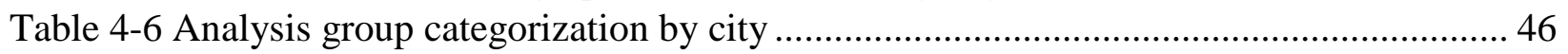

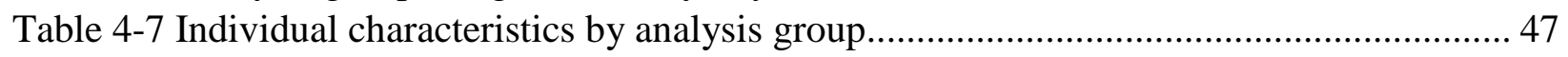

Table 4-8 Household characteristics by analysis group..................................................... 48

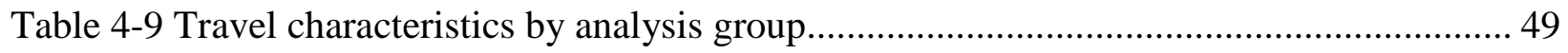

Table 5-1 Membership information .............................................................................. 52

Table 5-2 Cash membership process .............................................................................. 53

Table 5-3 How many of your family/friends/close acquaintances have [BssName] memberships?

Table 5-4 Open-ended responses - Why became a bike share member ................................... 55

Table 5-5 Sources of bike share information, and stated importance in decision to become a bike

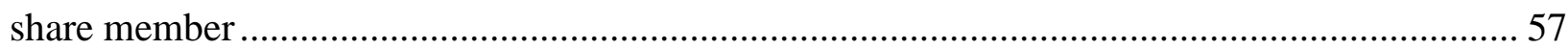

Table 5-6 Open-ended responses - How first learned about the bike share system .................... 58

Table 5-7 Bike share exposures, and stated importance in decision to become a bike share

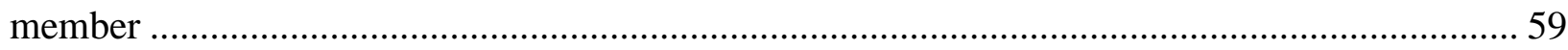

Table 5-8 Past users' reasons for no longer being a member/not renewing .............................. 60

Table 5-9 Past users: What might cause you to rejoin bike share ......................................... 61

Table 5-10 Likelihood of renewing current membership ....................................................... 61

Table 5-11 Undecided or unlikely to renew - Explanation of why..........................................6 62

Table 6-1 Bike share trips in a typical month in nice weather (current members) ...................... 63

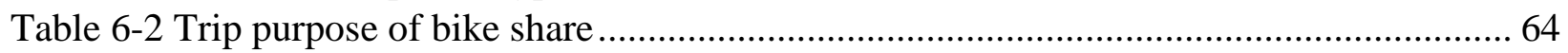

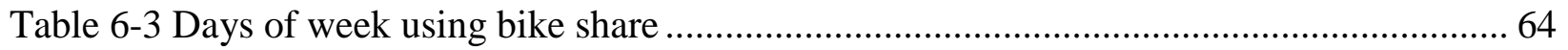

Table 6-4 Reasons for choosing bike share for a trip .......................................................... 66

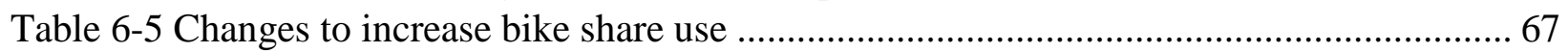

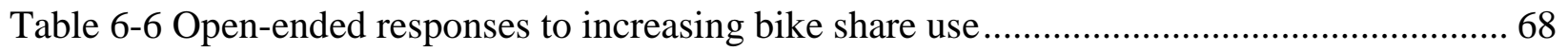

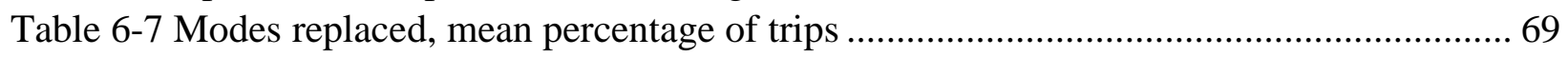

Table 6-8 Change in spending and exercise .................................................................. 71

Table 6-9 How is bike share important - Coded open-ended responses ................................. 72

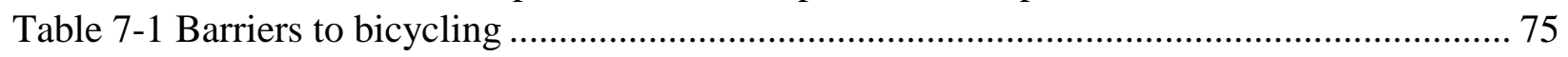

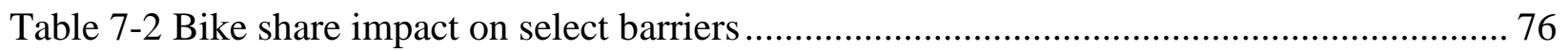

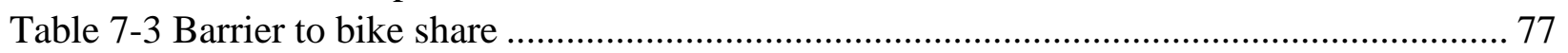


Table 7-4 Most important barrier - Open-ended responses .................................................... 78

Table 7-5 Open-ended - Why others do not use bike share ..................................................... 80 


\section{LIST OF FIGURES}

Figure 2-1 Philadelphia Strategic Business Plan (2013) conservative (left) and accelerated (right)

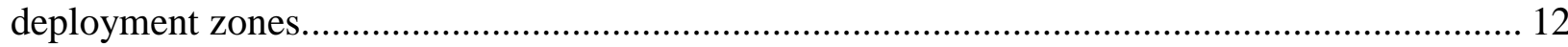
Figure 2-2 Indego bike share system development from launch through July 2016, including

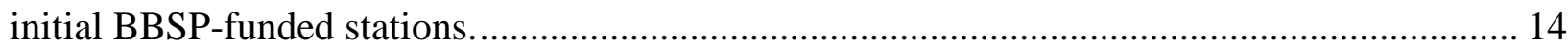
Figure 2-3 Philadelphia's BBSP outreach included a media and education campaign targeted to underserved populations. ............................................................................................. 18

Figure 2-4 Citi Bike bike share system development from launch through July 2016. .............. 20 Figure 2-5 Brooklyn targeted outreach media (left to right): bus shelter advertisement, Facebook promotion for Skills Class and Citi Bike Ride, community bike rides event flyer. ................... 23

Figure 2-6 Divvy bike share system development from launch through July 2016................... 26 Figure 2-7 Divvy for Everyone outreach included major media coverage, including a speech by the mayor at a launch event in Bronzeville.................................................................... 28

Figure 3-1 User survey sampling areas....................................................................... 33

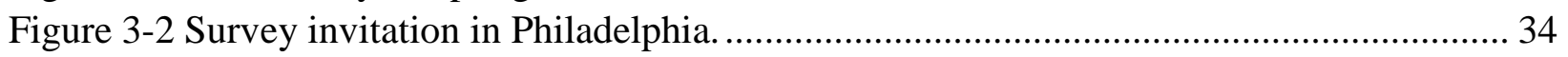

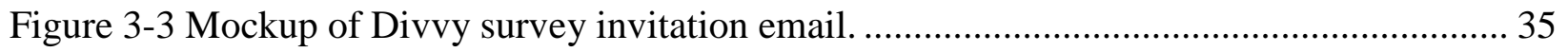

Figure 3-4 Citi Bike survey invitation email. .................................................................... 36 


\section{EXECUTIVE SUMMARY}

The findings in this report on bike share users provide a complementary examination, along with earlier companion reports on current efforts by bike share operations (NITC-RR-884a) and views of community residents (NITC-RR-884b), into the current state and potential impact of bike share on lower-income individuals and people of color. Specifically, this report seeks to provide more information about lower-income people and people of color who engage in the bike share, including why they choose to become members, how they use the system and how they benefit. The report looks at current and past bike share members, along with those who were involved in some type of equity-based outreach program.

The findings draw from a survey intended to reach lower-income and/or people of color known to have engaged in bike share, either through membership or participating in events such as organized rides, in the same three cities studied in the resident report (NITC-RR-884b) - New York (Brooklyn), Chicago and Philadelphia. With some variation by city, the survey was distributed to people who lived in or adjacent to neighborhoods targeted by equity-focused outreach efforts and had joined bike share, as well as people system-wide who participated in equity-focused programs, including discounts and events. The cities and neighborhoods were each targets of outreach and/or programming associated with the Better Bike Share Partnership (BBSP), a national coalition of organizations funding efforts to improve bike share equity.

Respondents were divided into three groups for analysis. Two groups consisted of users targeted for the equity-focused outreach efforts - lower-income individuals and people of color. One of these groups included those who took advantage of equity-focused discounts or related programs ("BBSP target users"); the other group included those who did not partake in such focused discounts or programs ("non-BBSP target users"). The third analysis group consisted of higherincome white users. Due to a larger sample and higher response rate, $80 \%$ of those who could be placed into one of these three groups were from Brooklyn. However, a large majority of these Brooklyn respondents were higher income and white. A majority (64\%) of the 70 BBSP target users were from Chicago, 21\% were from Brooklyn, and 14\% from Philadelphia. About half of BBSP target users were lower income and white, while the remainder were people of color, either lower or higher income.

Findings suggest that people in the BBSP target user group were less likely to have exposure to bike share through their existing networks (e.g., friends and family) or through their personal experiences (including using bike share in other places). BBSP target users were much less likely to have gotten information about bike share from their friends or family, with 33\% having done so, compared to $49 \%$ of white, higher-income users. Asked where they FIRST learned about bike share, only $12 \%$ of BBSP target users said friends and family, compared to a quarter of white, higher-income users. This disparity persisted even once participants had joined the system, with $34 \%$ of BBSP target users saying that they had NO friends, family or close acquaintances who 
were bike share members (compared to 22\% for non-BBSP target users and $13 \%$ of white, higher-income users).

BBSP target users were more likely to have exposure to bike share through some of the intervention methods used in the outreach efforts, such as finding out about bike share at events or finding out about available discounts for them. Among the sources that were more likely to be listed by BBSP target users than other respondents were talking to someone at an event (21\%), information at work or school (20\%), or from a newspaper (24\%). Further, 63\% of BBSP target users indicated that they had found out that they qualified for a discounted membership prior to joining, and $93 \%$ of those people said this was very important in their decision to join.

BBSP target users, in self-reported reasons for why they joined, were most likely to state either the cost savings or discounted membership, while other users were more likely to state the convenience of using bike share. This indicates that the discount programs are likely reaching people who would not otherwise join bike share. Moreover, about two-thirds of BBSP target users stated that they were "very likely" to renew their membership (the same as for the other groups) and they rode as frequently as other users. This is another indication that the discount programs are effective. Target users were more likely to pay monthly for bike share. However, in cities that offer a monthly and annual payment option, it could mean that lower-income people and people of color will be paying a higher effective rate than higher-income, white members.

In terms of bike share usage, all respondents were generally frequent users, with over half indicating that they make 11 or more bike share trips per month in good weather and a third reporting making 20 or more trips per month. This suggests that once target users become members, perhaps with the help of a discount membership, they may use bike share as often as white, higher-income users. BBSP target users were more likely to ride just for fun or for exercise. Further consideration of potential for recreation and exercise use of bike share among target populations appears to be warranted.

Though not a large share of bike share trips, BBSP target users were also more likely to use bike share for school, daycare or religious-related trips, as well as for trips related to looking for work or job/skill training. More in-depth examination is needed of these low frequency but potentially high value bike share trips.

Overall, exercise, time savings and convenience/flexibility were the most commonly stated benefits of bike share. BBSP target users were a bit more likely to ride just for fun or for exercise (about three-quarters had done so, compared to just under half of white, higher-income members). White, higher-income users were also more likely to report only using bike share on weekdays (43\% said so), while others were more likely to say they use bike share equally during the week and on weekends.

Among all respondents, about half indicated that they were spending less on transportation overall, generally, through spending less on public transit or taxi (or ride-hailing and carsharing services) rides, though a quarter also told us they were spending less on costs associated with driving a personal car. BBSP target users reported saving the most, with a quarter of respondents in that group reporting saving \$21 or more per week, and a majority saving more than \$6 per 
week. Most of those receiving discounts were realizing savings that exceeded the discount amount, an encouraging sign for the value of the program and for retaining those members even if discounts end.

The top barrier to using bike share more in the user survey was that of distances being too far to bike, at rates similar to the resident survey. For current users, regardless of user group, more stations, bikes and docks were viewed as the things that would make them most likely to use bike share more, and a lack thereof acting as a barrier to use. Better quality bike infrastructure/routes were noted as things that would make them ride more and (a lack of them) as key barriers. A majority of the BBSP target users, more so than the other groups, indicated that having longer time limits on bike share rides would encourage them to use it more. This may be linked to both using bike share for exercise and concerns about having to pay for longer trips. The target users were also more likely to increase their use if the fees for longer trips were lower. These findings indicate that changes to pricing structures may encourage more use among lower-income people and people of color. Time limits and excess time penalties should be further examined as potential barriers to greater use among target populations. 


\subsection{INTRODUCTION}

\subsection{BACKGROUND}

In less than 10 years, public bike share systems have increased from operating in a few select European cities to expanding in North America at an increasing pace, with over 40 new bike share systems launched in 2016. As of mid-2017, 153 bike share systems are in operation (or due to be launched this year) in the United States (McNeil et al. 2017). Despite the appeal and growth of bike share in the U.S., there is evidence that certain groups are participating less and enjoying fewer benefits from this new transportation option than the general population. People of color, along with lower-income, female, older and less-educated groups appear to be underrepresented among bike share users, and even less likely to become regular members. Part of the divide can be attributed to a lack of bike share stations in communities where a greater share of residents is from these demographic groups, but further evidence suggests station access is necessary but not sufficient to overcome persistent barriers to use and membership.

The Better Bike Share Partnership (BBSP) - a collaboration among the City of Philadelphia, the Bicycle Coalition of Greater Philadelphia, the National Association of City Transportation Officials (NACTO), and PeopleForBikes - has been working with cities around the U.S. to bring the benefits of bike share to underserved communities, particularly communities of color and lower-income individuals, while promoting increased levels of system use. The BBSP collaboration is made possible by funding from The JPB Foundation. The primary efforts have involved the placement of bike share stations in lower-income and racially diverse neighborhoods; targeted outreach to these communities that have been traditionally underserved by bike share; and changes to the payment systems, pricing structures and, in some cases, significantly reduced prices for memberships or passes.

\subsection{RESEARCH OVERVIEW}

This report is part of a larger research project undertaken in cooperation with the BBSP to evaluate the effectiveness of its efforts, and to better understand the challenges of and opportunities for expanding the reach of bike share systems to be more equitable. Primary research questions include:

- How does bike share work for specific underserved and understudied populations, and how might their needs and use patterns differ from other user groups?

- Are there specific barriers and opportunities among these populations that either match, extend or differ from those identified in existing studies?

- Which improvements or changes to the system or outreach may provide the largest returns in terms of actual or planned use of bike share in underserved communities? 
The research can also address supplemental questions, including whether bike share can connect disadvantaged groups to services, education and economic opportunities, and whether and how different urban environments and amenities affect bike share use and outreach success.

The overall project has three main components, each collecting information from a different set of individuals and presented in separate reports:

- Bike Share Owners and Operators. To better understand current efforts nationally to make bike share more equitable, we first conducted a survey of bike share system owners and operators (report NITC-RR-884a). The survey asked about equity policies and metrics; the degree to which equity considerations affected a variety of system practices; what the existing barriers to utilizing bike share are for target populations; and what challenges the bike share system entity faces in addressing those barriers.

- Residents. The second part of the research effort was a survey of residents living in predominantly low-income and/or racially diverse neighborhoods in Philadelphia, Chicago and Brooklyn that had been targeted by efforts associated with the BBSP (report NITC-RR-884b). The survey sought to understand how these residents perceive and interact with bike share and bicycling more generally. The survey used a random sample of people living near bike share stations in the neighborhoods, rather than people already known to have used or shown interest in bike share. The resident survey was designed to answer all of the research questions listed above, and allows us to learn from people who have and have not used bike share.

- Bike Share Users. Finally, this report (NITC-RR-884C) presents findings from a survey of bike share users and other people who have had some interaction with BBSP outreach efforts in the three cities. The objective is to get a more in-depth understanding of the populations reached by the efforts and how the efforts may have influenced their behavior. The findings complement the resident survey, which only has a small sample of bike share users.

Each report will be available at the project website: http://trec.pdx.edu/research/project/884.

\subsection{LITERATURE REVIEW}

In addition to the following overview of existing research on bike share and bicycling equity, we encourage the interested reader to peruse the longer review and literature overview tables in the resident report (Breaking Barriers to Bike Share: Insights from Residents of Traditionally Underserved Neighborhoods, NITC-RR-844b), Tables 2-2 and 2-3. This section represents a condensed version of that longer literature review, with a few additions specific to bike share use characteristics (Section 1.3.4). In general, existing studies support the conclusion that there are disparities in bike share participation by race, income, gender, age and education level. Other research has focused on how people use bike share. Few studies have looked at how different sociodemographic groups' uses of bike share might differ. Bike share users from groups with 
lower participation rates could provide useful insights into targeted policies and outreach to make bike share work better for those market segments.

\subsubsection{Race}

Studies across a number of systems have shown wide disparities in participation by race. Generally speaking, Black populations experience the largest disparities, and racial divides are wider for bike share members than for casual, walk-up users. A study of members in Minneapolis, Salt Lake City, Toronto and Montreal reported shares of Black members substantially lower than among the general population (Shaheen et al. 2014). Hispanic membership shares were also lower, except in Montreal. Surveys of Washington, D.C.'s, Capital Bikeshare system also found lower participation rates among Black residents, whether comparing to the D.C. area general population or regional cyclists (Buck et al. 2013; Virginia Tech University 2012). Interestingly, the same studies found that Hispanics were underrepresented as Capital Bikeshare users relative to the general D.C. population, but overrepresented relative to regional cyclists. When people of color do participate in bike share, they are more likely to do so as casual users than as members (Buck et al. 2013; Shaheen, Christensen and Viegas de Lima 2015; Virginia Tech University 2012).

One factor that could explain racial differences in bike share use is station siting. Research has consistently shown that bike share use falls dramatically when stations are more than about a quarter-mile walk (Bachand-Marleau et al. 2012; Fuller et al. 2011; Ogilvie and Goodman 2012). Ursaki and Aultman-Hall (2015) reported significantly lower-than-expected Black population shares within bike share service areas in six out of seven U.S. cities studied (Arlington, VA, was the exception). Chicago, New York and Boston were particularly unbalanced, with shares of Black residents near bike share stations less than half that of areas without stations.

Even in studies controlling for bike share proximity, participation appears to lag behind for people of color and in neighborhoods with fewer white residents. A 2015 study in Philadelphia sampled residents or employees within a 10-minute walk of specific bike share stations (Hoe 2015b). Despite similar station access, Black respondents were significantly less likely to have used bike share than were white respondents, and Black respondents still made up a much smaller share of members than casual users among those surveyed. Rixey (2013) modeled station use in Washington, D.C., Denver and Minneapolis, controlling for a range of neighborhood characteristics, including population and station density. For each 10 percentage-point increase in non-white population share, ridership for a neighborhood station was predicted to be about $23 \%$ lower, with all else equal.

\subsubsection{Income and related factors}

Lower-income populations have also been thought to participate in bike share at lower rates, though the evidence is somewhat more mixed than for race. Shaheen et al. (2014) reported lower-than-expected membership rates across four U.S. and Canadian systems for those with annual income less than $\$ 25,000$, while those earning $\$ 100,000$ or more joined at rates 
considerably higher than their share in the general population. On the other hand, Buck et al. (2013) reported that compared with just the Washington, D.C., cycling population, Capital Bikeshare members had somewhat lower incomes. In San Francisco, those earning less than $\$ 15,000$ per year made up 5\% of surveyed casual users versus just $1 \%$ of Bay Area Bike Share members, while those earning more than $\$ 200,000$ comprised $24 \%$ of members but just $13 \%$ of walk-up users (Shaheen et al. 2015).

Income disparity in station siting has been noted as one barrier to bike share use. Ridership goals may favor wealthier, higher-density station locations. A study of 42 U.S. bike share systems found that the $60 \%$ of census tracts with greatest economic hardship contained less than $25 \%$ of bike share stations (Smith, Oh and Lei 2015). However, Ursaki and Aultman-Hall (2015) presented more mixed results from New York City; Boston; Washington, D.C.; Arlington, VA; Chicago; Denver; and Seattle. The share of residents earning less than $\$ 20,000$ per year was actually significantly higher near bike share stations in three of the seven cities and significantly lower only in Washington, D.C. On the other hand, the share of those earning more than $\$ 100,000$ was also significantly higher near stations in three of the cities, but significantly lower only in Seattle.

Three additional income-related factors - access to credit/debit cards, the internet and smartphones - may serve as additional barriers to bike share participation. Most of the bike share programs require a credit card to be a member, but many people in the U.S. do not have a bank account (the "unbanked") or credit card. Approximately 7\% of U.S. households did not have a bank account in 2015, and among those earning less than \$30,000 per year unbanked rates ranged from $12 \%$ to $26 \%$ (FDIC 2015). Many programs also require internet access to sign up for their memberships, but many lower-income residents do not have reliable access to the internet at home. Just over a quarter of U.S. adults in households making less than $\$ 30,000$ per year report not using the internet, compared with just $3 \%$ in households earning $\$ 75,000$ or more (Perrin and Duggan 2015). Even those having regular internet access might be disadvantaged in using modern bike share systems if they do not have a smartphone to, for example, aid in locating stations with available bikes or return slots. In U.S. households earning less than $\$ 30,000$ per year, only half of adults reported owning a smartphone, compared with $84 \%$ in household earning \$75,000 or more (Pew Research Center 2015).

\subsubsection{Age and education}

Bike share participation tends to be higher among younger, more educated populations. Whether focused on age in general (Bachand-Marleau et al. 2012; Hoe 2015b) or specific age groups such as those under 34 (Buck et al. 2013; Fuller et al. 2011), those 25 to 34 (Shaheen et al. 2014), or those 20 to 39 (Daddio 2012), research from a wide range of systems has found younger people consistently overrepresented as bike share members and users. Education has similarly been found positively correlated with bike share use and membership. Research across multiple systems has found increasing use among those with college degrees (Fuller et al. 2011; Shaheen et al. 2015; Shaheen et al. 2014). Less-educated residents may be more likely to participate as casual users rather than as members (Virginia Tech 2012). 


\subsubsection{Existing bike share use patterns}

Research on those using bike share -typically collected via either member surveys or by intercepting casual users at stations -has mainly focused on describing patterns of use, including frequency, trip purpose, travel modes (e.g., transit, driving, walking) replaced by bike share. A handful of these studies have considered sociodemographic differences in usage patterns. Additional studies have considered potential outcomes of bike share use such as changes in exercise levels. Worth noting is that, since bike share use tends to fall off sharply away from the center of a system, surveys of users will tend to reflect primarily a bike share system's core and less so the periphery. Our study areas, in contrast, fall largely in neighborhoods at the edge of current system expansion and, therefore, would be expected to exhibit different use patterns than existing surveys, even leaving aside any demographic differences.

In terms of frequency of bike share use, the majority of members surveyed in Washington, D.C., used bike share from one to 10 times per month, with a somewhat surprising portion (more than 15\%) reporting no use in a typical month (Buck et al. 2013). Men (35\%) were more likely than women (20\%) to use bike share more than 10 times per month. Surveys in both Washington, D.C., and Minneapolis show that members most typically use bike share for short trips, with about a third of trips in both cities taking between five and 10 minutes (Shaheen, Martinand Chan 2012). Nearly $90 \%$ of trips in both cities ended before additional charges began after 30 minutes.

Another area of interest is the type of trip taken via bike share. Trips to and from work or school have been the most common trip type reported in a number of North American cities, representing from 43\% to 56\% of trips (Buck et al. 2013; Shaheen et al. 2012). Most trips are taken by bike share members to get from place to place, with only 2-7\% of trips primarily for exercise or recreation (Buck et al. 2013; Shaheen et al. 2012). Exercise use is more common among casual bike share users, with studies in Washington, D.C., and San Francisco reporting $15 \%$ to $18 \%$ of walk-up user trips for recreation (Buck et al. 2013; Shaheen et al. 2015). While they might make up a small share of total trips, exercise use may still be common. An intercept survey of all users in Philadelphia discovered that 28-30\% of respondents had used bike share for exercise at least once, with African-Americans (57\%) and Hispanics (80\%) more likely to have done so (Hoe 2015). Majorities of respondents in Montreal, Toronto Minneapolis (58\% to 73\%) agreed that they were getting more exercise since joining bike share (Shaheen et al., 2012).

People may use bike share in place of other mode options or, in some cases, may use it for trips that they otherwise would not have taken. Findings from North America suggest that bike share travel most commonly replaces walking (31-68\%) and public transit (20-45\%), with smaller shares drawn from driving (1-20\%) (Buck et al. 2013; Fishman, Washington and Haworth 2014; Shaheen et al. 2015). Between about $2 \%$ and $9 \%$ of surveyed bike share use is new travel (Buck et al. 2013; Fishman et al. 2014). Additional research cautions that although, on average, bike share displaces transit and walking, this is not true for everyone. Some respondents (5\% to 28\%) reported using transit more after becoming bike share members, and substantial shares also reported more walking (17\% to 37\%) (Shaheen, Martin and Chan 2012; Shaheen, Martin, Cohen 
and Hall 2013). Not surprisingly, the majority of bike share members (71\% to 82\%) report increases in cycling (Shaheen, Martin and Chan 2012; Shaheen, Martin, Cohen and Hall 2013).

Our interest was in whether the existing results, drawn largely from typical bike share users from a handful of systems, would differ among our sample of lower-income people, communities of color, and more geographically peripheral neighborhoods and respondents.

\subsubsection{Use of and barriers to bicycling}

In addition to understanding existing research on issues related to equity in bike share, past findings related to equity in bicycling, in general, are also important to address. Costs associated with buying and maintaining a bicycle, access to safe bicycle routes, and some social and cultural perceptions (and stigmas) are barriers to riding a bicycle for lower-income populations and people of color (CCC 2012; Dixon et al. 2015; Brown and Sinclair 2016; NAR and PSU 2015). The full literature review in report NITC-RR-884b provides further detail.

\subsection{BIKE SHARE POTENTIAL FOR UNDERSERVED COMMUNITIES}

Efforts to address equity and bike sharing are underway in a number of cities. System operators do seem to be aware of siting disparities. One study found that 10 of 23 (43\%) surveyed bike share programs factored equity considerations into bike share station siting decisions (Shaheen et al. 2014). A more recent survey of 54 operators found that for $68 \%$ of the systems, equity was considered and influenced station siting decisions (Howland et al. 2017).

However, even with this awareness, research shows limited success in addressing these underserved communities. A recent set of case studies discussing several U.S. cities' attempts to connect low-income individuals to bike share found that despite some successes via subsidized memberships to overcome cost barriers, difficulties persisted through a lack of stations in communities with poor transit access and in low-income communities in some cases, and low use of stations in such communities in other cases (Kodransky and Lewenstein 2014). Community engagement is likely a key factor in efforts to make bike sharing more equitable and to serve low-income people and communities of color. One early study found that siting stations in low-income communities in Minneapolis yielded limited ridership, likely due to a lack of ongoing community engagement (Stewart et al. 2011). 


\subsection{BACKGROUND}

This report describes findings from surveys of bike share users or people known to have participated in bike share outreach in one of three cities: Philadelphia, Chicago and Brooklyn. Efforts were made to improve the equity outcomes of their bike share systems as participants in the Better Bike Share Partnership (BBSP or the partnership).

Portions of this "Background” chapter are identical to the companion report NITC-RR-884b, as they apply equally to this report.

\subsection{THE BETTER BIKE SHARE PARTNERSHIP}

In mid-2014, the partnership got underway with funding from The JPB Foundation. The stated goal of the partnership is "to build equitable and replicable bike share systems." The City of Philadelphia took a lead role in managing BBSP activities, along with partners including the Bicycle Coalition of Greater Philadelphia, the National Association of City Transportation Officials (NACTO), and PeopleForBikes.

The partnership, particularly through the City of Philadelphia and the Bicycle Coalition, focused considerable effort on making the launch and operation of Philadelphia's bike share system, Indego, a system that worked for underserved communities. The initial effort in Philadelphia employed a multi-tiered approach including: grant-funded placement of bike share stations in underserved neighborhoods; targeted outreach including education, organized rides and media; and improvements to earlier bike share system membership and payment standards (including monthly as opposed to annual passes, and cash payment options).

Beyond Philadelphia, PeopleForBikes administered BBSP-funded grants to cities around the country to carry out activities geared toward making their bike share systems more equitable. In year one (2015-2016), six cities received grants ranging from $\$ 20,000$ to $\$ 75,000$ to carry out a variety of efforts. Recipients included Austin, Boston, Brooklyn, Charlotte, Chicago and Washington, D.C. Ten cities received grant funding in year two (2016-2017). Chicago, Boston and Brooklyn received ongoing funding, and new awards were granted to Atlanta; Basalt, CO; Los Angeles; Milwaukee, WI; Minneapolis; Oakland/Berkeley, CA; and Portland, OR. Grant recipients within each locale included bike share operators, community-based nonprofits including bicycle-focused organizations, city agencies or departments, or combinations of these. Many BBSP grantees have also sought additional funding streams to complement their grantrelated efforts.

Grantee cohorts receive technical assistance from PeopleForBikes and other BBSP partners. Each cohort was launched with a meeting for grantees to discuss barriers, approaches and programs related to bike share equity efforts. Monthly conference calls provide forums to discuss challenges and accomplishments with peer practitioners and organizations in other cities. In several cases, delegations from grantee cities have visited other grantee cities to learn about the 
challenges and successes of their peers. The partnership also hosted a national Bike Share Equity Conference in Philadelphia in June 2016.

A goal of both the Philadelphia program and nationwide efforts is to pilot and evaluate a range of efforts geared toward improving equity outcomes of bike share, with the knowledge that because this challenge has only recently been identified, empirical data and research are currently limited. Therefore, BBSP also provided funding for research and development of practical tools to improve understanding of equity and bike share, and access to tools for public agencies and practitioners. Research funding was provided to Temple University and Portland State University (this research). NACTO worked to develop tools for practice and to disseminate BBSP-related knowledge more broadly. In addition, many grantees are conducting their own evaluations and research related to local experiences with BBSP.

Through the BBSP's efforts, cities hope to learn more about the effectiveness, cost and sustainability of a range of potential approaches. Promising projects could then be carried on beyond the grant timeline, and hopefully inform other cities, bike share systems and community partners around the country as they seek to improve equity outcomes in their own bike share programs. An overview of BBSP efforts is provided for each study city in Table 2-1, and specific details are presented by city in the remainder of this chapter.

Table 2-1 Overview of BBSP context and program elements by study city

\begin{tabular}{|c|c|c|c|}
\hline & Philadelphia & Chicago & Brooklyn \\
\hline Bike share context & $\begin{array}{l}\text { Indego launched in } \\
\text { April 2015, including } \\
\text { stations in BBSP target } \\
\text { areas (BBSP-funded). }\end{array}$ & $\begin{array}{l}\text { Divvy launched in } \\
\text { June 2013, with some } \\
\text { stations in the } \\
\text { Bronzeville district. } \\
\text { Additional stations } \\
\text { added in spring } 2015 \\
\text { and spring } 2016 .\end{array}$ & $\begin{array}{l}\text { Citi Bike launched in May 2013, with } \\
\text { some stations on the western edge of } \\
\text { the Bedford-Stuyvesant neighborhood. } \\
\text { Expansion into central Bed-Stuy in } \\
\text { August } 2015 \text {. }\end{array}$ \\
\hline $\begin{array}{l}\text { Discount pass } \\
\text { option }\end{array}$ & $\begin{array}{l}\text { Not until April } 2016 \\
\text { (Indego30 Access). }\end{array}$ & $\begin{array}{l}\text { From July } 2015 \\
\text { (Divvy for Everyone, } \\
\text { D4E). }\end{array}$ & $\begin{array}{l}\text { From launch, discount for public } \\
\text { housing residents (NYCHA) and } \\
\text { Community Development Credit Union } \\
\text { (CDCU) members. }\end{array}$ \\
\hline $\begin{array}{l}\text { Cash payment } \\
\text { option }\end{array}$ & Yes & Yes, only for D4E & No \\
\hline $\begin{array}{l}\text { Primary BBSP } \\
\text { outreach activities }\end{array}$ & $\begin{array}{l}\text { Cash payment system, } \\
\text { public internet } \\
\text { locations, group rides, } \\
\text { attended } \\
\text { events/meetings, } \\
\text { advertising campaign, } \\
\text { digital literacy and } \\
\text { bike riding classes } \\
\text { (“Digital Skills and } \\
\text { Bicycle Thrills”), } \\
\text { surveys and focus } \\
\text { groups. }\end{array}$ & $\begin{array}{l}\text { Divvy for Everyone } \\
\text { program promotion, } \\
\text { group rides, attended } \\
\text { events, incorporated } \\
\text { into personal credit- } \\
\text { building program. }\end{array}$ & $\begin{array}{l}\text { Demonstrations of bicycles/system use, } \\
\text { special events, organized rides, surveys } \\
\text { and focus groups, targeted promotion } \\
\text { to NYCHA residents, incorporated into } \\
\text { financial literacy program, and } \\
\text { prescribe-a-bike at two Bed-Stuy } \\
\text { locations. }\end{array}$ \\
\hline
\end{tabular}




\subsection{PHILADELPHIA}

\subsubsection{System: Indego}

The City of Philadelphia began exploring bike share as early as 2009. A 2013 bike share strategic business plan proposed a phased rollout focusing on the downtown core first (Zone 1A), and a year-one expansion into inner neighborhoods (Zone 1B) (Figure 2-1). Then-Mayor Michael Nutter tasked the Mayor's Office of Transportation and Utilities (MOTU - now the Managing Director's Office of Transportation and Infrastructure Systems, or OTIS) with ensuring that bike share served all Philadelphia residents, including traditionally underserved communities. In late 2013 and early 2014, MOTU applied to The JPB Foundation for funding for the Better Bike Share Partnership with the goal of prioritizing equity in the Philadelphia bike share system, and promoting bike share equity around the country. Philadelphia used a portion of the grant funding to include both zones in the initial rollout in an "accelerated" version of the plan (Figure 2-1). Intensive outreach throughout the entire Zone 1 designated area culminated in the launch of a 71-station system in April 2015, with two neighborhood stations added shortly afterward to cover all of Zone 1.
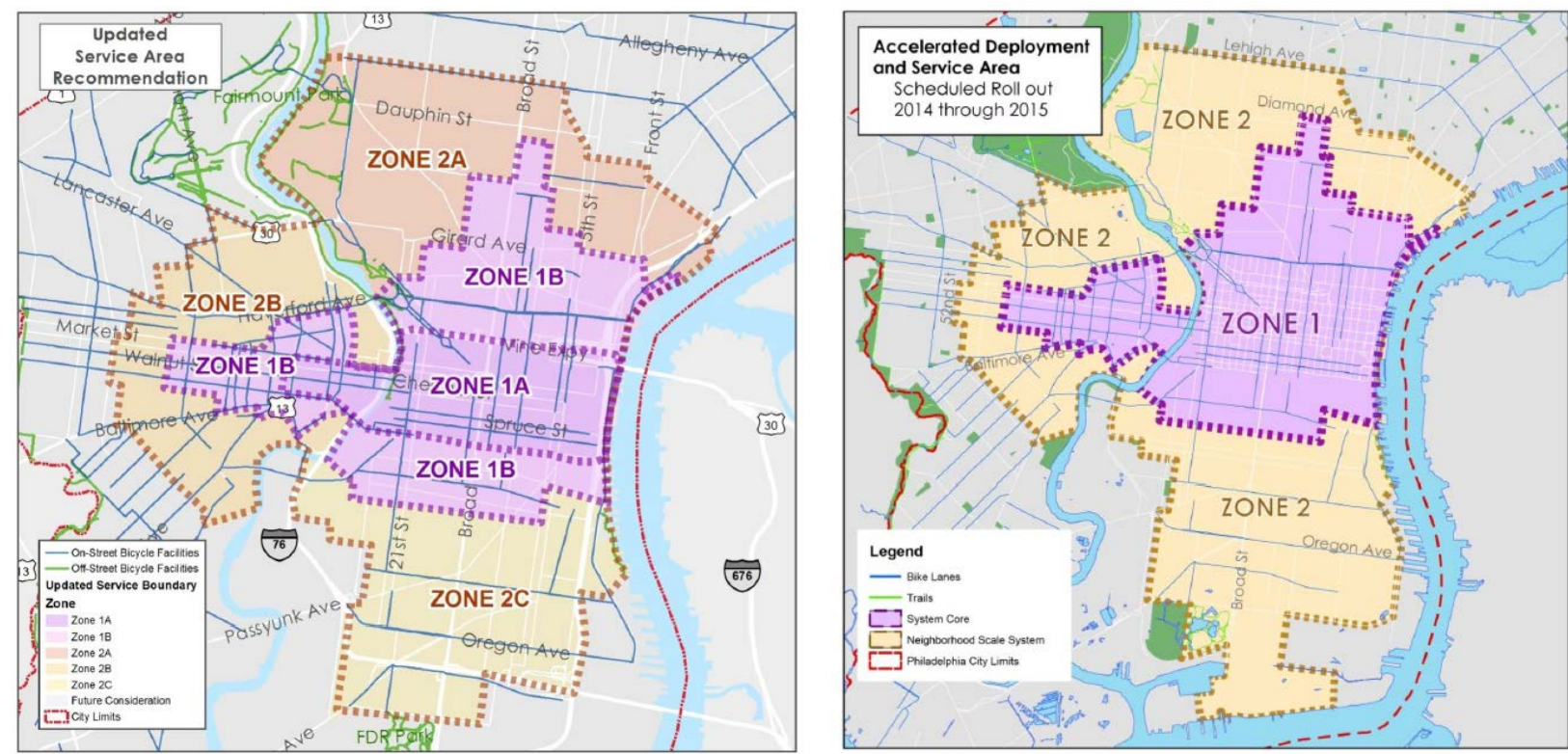

Figure 2-1 Philadelphia Strategic Business Plan (2013) conservative (left) and accelerated (right) deployment zones.

Philadelphia's bike share system, Indego, including the bicycles and station equipment, is owned by the City of Philadelphia and managed by OTIS. The title sponsor of the system is Independence Blue Cross. The equipment is manufactured by BCycle, and is operated by Bicycle Transit Systems. By the end of 2015, the 73 stations were stocked with approximately 700 bicycles. From April 2016, the system has subsequently expanded with additional stations 
and bicycles. As of summer 2016, there were 105 active stations in the system. ${ }^{1}$ The development of the system up to the point of our survey is shown in Figure 2-2.

\subsubsection{Equity initiative}

Philadelphia's priority focus on equity from the planning stages of its bike share system made Indego unique among large U.S. systems. Along with the system's owner and operator, the Bicycle Coalition of Greater Philadelphia (BCGP) has been a key partner in Indego equity efforts, particularly around outreach and education.

Bike share stations in low-income communities. BBSP funding provided for up to 20 bike share stations in underserved communities in Philadelphia. Philadelphia has a number of relatively dense low-income neighborhoods directly adjacent to the city center. In the planning phase of the system, the city identified neighborhoods and specific site locations for stations in areas of South Philadelphia (Point Breeze), West Philadelphia (Powelton Village, Mantua, University City and Spruce Hill), and North Philadelphia (Spring Garden, Poplar and Francisville).

${ }^{1}$ https://www.rideindego.com/about/data/ 


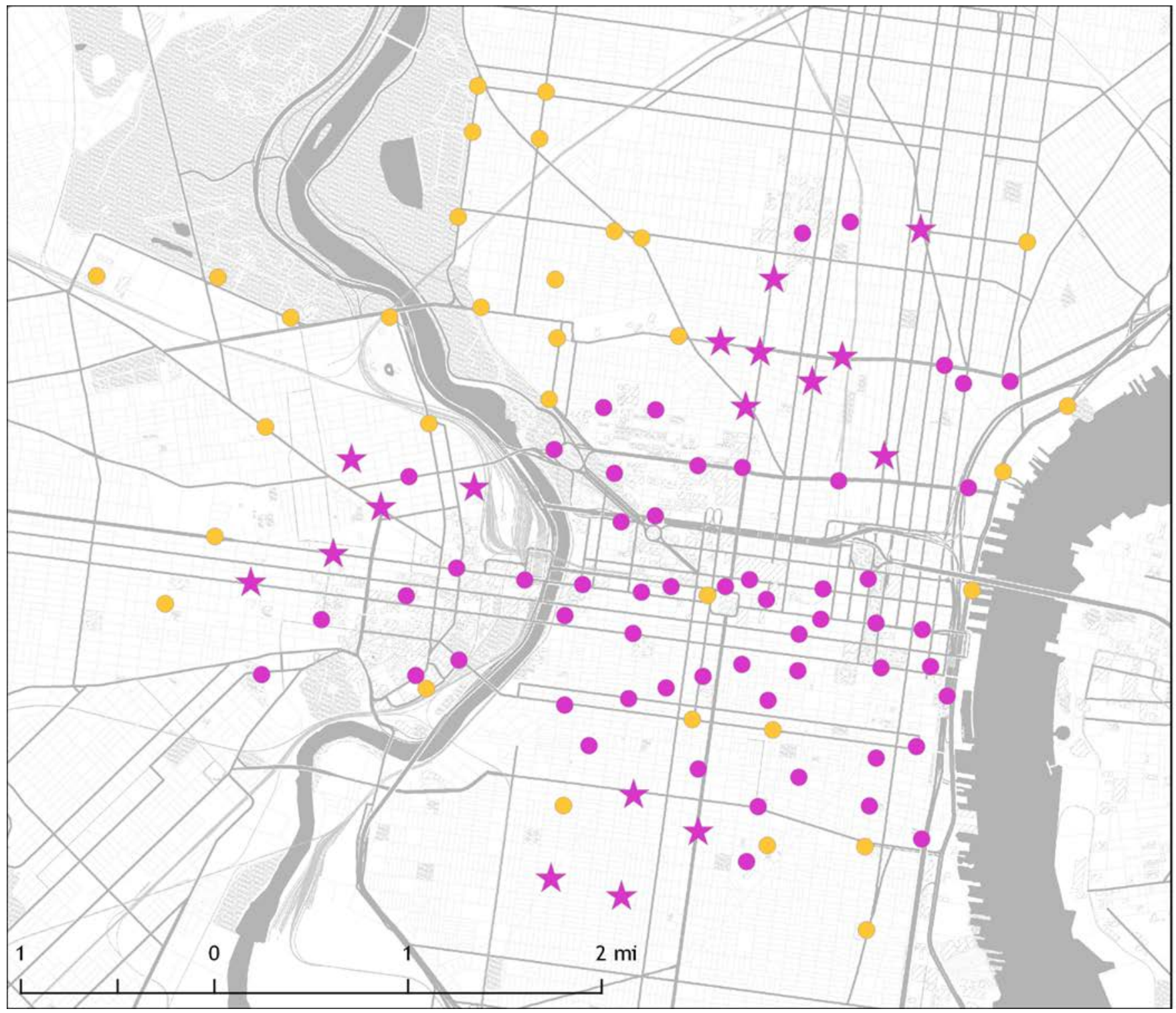

\begin{tabular}{|l} 
Indego System \\
$\quad 2015$ \\
$\star 2015$, BBSP-funded \\
$\quad 2016$
\end{tabular}

Figure 2-2 Indego bike share system development from launch through July 2016, including initial BBSP-funded stations. 
The city began outreach in these neighborhoods (and other Philadelphia neighborhoods targeted for bike share stations) in summer 2014, and scheduled between two and five community meetings for each location in the fall. Decisions about site locations were focused on connecting people to transit, parks, community centers and grocery stores. In conjunction with community input, site visits to specific potential locations were conducted. Due to the limited right-of-way on many Philadelphia streets, station location decisions were often constrained to a small number of feasible sites. Stations were generally placed on sidewalks and other areas where parking removal was not required. In general, community feedback was positive; however, in a few instances, particularly in North Philadelphia, specific station locations met with community resistance and were not installed.

At the time of the system launch, 17 stations were purposefully located in underserved areas and supported by BBSP funding. These stations were originally in the designated Zone 1B, but in fact opened at system launch.

Payment systems. Payment system characteristics may present an additional challenge to lowerincome and minority communities. Indego undertook several measures aimed at making the payment options more appealing and accessible for a broader spectrum of users who may not be able to or be interested in committing to long-term memberships or using credit or debit cards for payment.

Pass and use options. With many bike share systems that launched prior to Indego, users who wanted the best deal to use bike share regularly had to commit to annual memberships, typically priced from $\$ 75$ to $\$ 150$. Depending on the system, this amount might be due up front or, less commonly, split into monthly payments with an annual commitment (and often at a higher total price than a single payment). For lower-income users, committing to pay these larger sums (particularly for new users who might still be testing out whether they are truly interested in bike sharing) could represent a considerable financial or psychological barrier. Frequent users without such an annual membership would likely be required to purchase more day or weekly passes, targeted more toward tourists, that cost considerably more per ride or per day - in some cases approaching the cost of a full month's membership for just a day of riding.

To better address payment barriers, Philadelphia created multiple options: a \$15 monthly bike share pass with no annual commitment (Indego30); a \$10 annual pass that allows check-outs for \$4 per hour; and a \$4 per 30 minutes walk-up option. The walk-up option would allow prospective users to try out Indego for less than the lowest-cost option in most other systems (typically an \$8-\$10 day pass). These measures were designed in part to allow curious customers to try out the system without a major commitment. The payment structure also allows longer check-outs (the first hour is no extra charge for pass-holders) than most systems, and additional time is charged at a flat rate (\$4/hour with a pass, $\$ 4 /$ half-hour for walk-up users). This may be a particular benefit to new users who are not familiar with all of the stations or routes.

Although the initial annual rate of $\$ 15$ per month, up to $\$ 180$ per year, was more expensive than typical bike share systems, the structure also allowed users to join and opt out at will. Users 
could, for example, join only for one month when they had a particular need, or only during the summer, not paying for months when they were not using the system.

Payment options, including cash option. Indego was also the first major U.S. bike share system to offer a cash payment option. The City of Philadelphia decided that providing a cash payment option was a priority based on studies showing that lower-income and minority individuals were more likely to lack a credit or debit card.

Bicycle Transit Systems researched potential options and developed a system wherein people could sign up online (including using publicly accessible internet locations such as "Keyspot" sites - https://www.phillykeyspots.org/), and receive a code through the vendor PayNearMe. That code could be taken to a local 7-Eleven or Family Dollar store and presented to the cashier along with the appropriate payment, and the funds would be credited to the user's Indego account. New members would then be mailed an Indego pass.

Discounted membership option. In April 2016, Indego added a \$5 per month pass option for those meeting income qualifications (Indego30 Access), with overage charges at a reduced rate of $\$ 2$ per hour. No annual commitment is required. Eligibility is tied to the PA Access cards the State of Pennsylvania issues to eligible recipients of various benefits such as cash assistance programs, Supplemental Nutrition Assistance Program (SNAP), and medical assistance. By August 2016, nearly 700 members had joined via the Access program, with almost 20\% opting to pay with cash. ${ }^{2}$

Outreach efforts. The Bicycle Coalition of Greater Philadelphia (BCGP) played a leading role in community outreach and education, particularly around barriers more specific to bicycling generally. Full-time coalition staff and several teams of part-time and stipend-supported people conducted extensive outreach in each of the three focus areas (North, South and West Philadelphia). In general, BCGP sought representatives who already had standing in the specific communities, including key community agencies, organizations and leaders. Both pre- and postlaunch, BCGP staff attended numerous meetings, events and gatherings in each of the neighborhoods to discuss Indego and explain how the system worked. They brought Indego bikes to the events and offered rides to those interested. Over time, outreach included more organized rides and classes.

Outside of BCGP full-time staff, two groups of outreach leaders were brought on board:

- The "Street Team" consisted of young adults in the community who were hired on a parttime basis over the summer and on weekends. Street team members were tasked with being the outward face of Indego at community events and providing one-on-one interaction with community members.

- The Ambassadors program consisted of about 20 people who lived or worked in the various outreach communities and were active in the community. The role of the

\footnotetext{
${ }^{2}$ http://betterbikeshare.org/2016/08/29/philly-offering-bike-share-discounts-food-stamp-cards-working-great/
} 
Ambassadors was to build on their existing relationships to strengthen support for bike share in the community. For a modest stipend, they were expected to attend a training, organize bicycling street skills classes and community rides, and attend Indego-related events.

BCGP staff, Street Team members and Ambassadors attended events such as festivals and fairs, markets, block parties and community days, setting up pop-up information tables at busy locations or centers. They also led bike rides, some of them using Indego bikes, and trained people through classes and ad-hoc lessons on bicycling and how to use bike share. A month-long adult education course was offered - "Digital Thrills and Bicycle Thrills" - that combined digital literacy with learning about Indego. ${ }^{3}$ Those who completed the course were eligible for a free, six-month bike share pass.

The City of Philadelphia and Bicycle Transit Systems also sought to spread the word about Indego through social media campaigns and advertising on billboards, buses and bus shelters. In each of these campaigns staff members, informed by focus groups, worked to ensure that images and information would appeal and be accessible to all residents, including those in traditionally underserved populations. Some of the models in the advertising campaign were part of the BCGP Ambassadors team. Examples are provided in Figure 2-3.

${ }^{3}$ https://www.rideindego.com/blog/sign-up-for-digital-skills-and-bicycle-thrills/ 


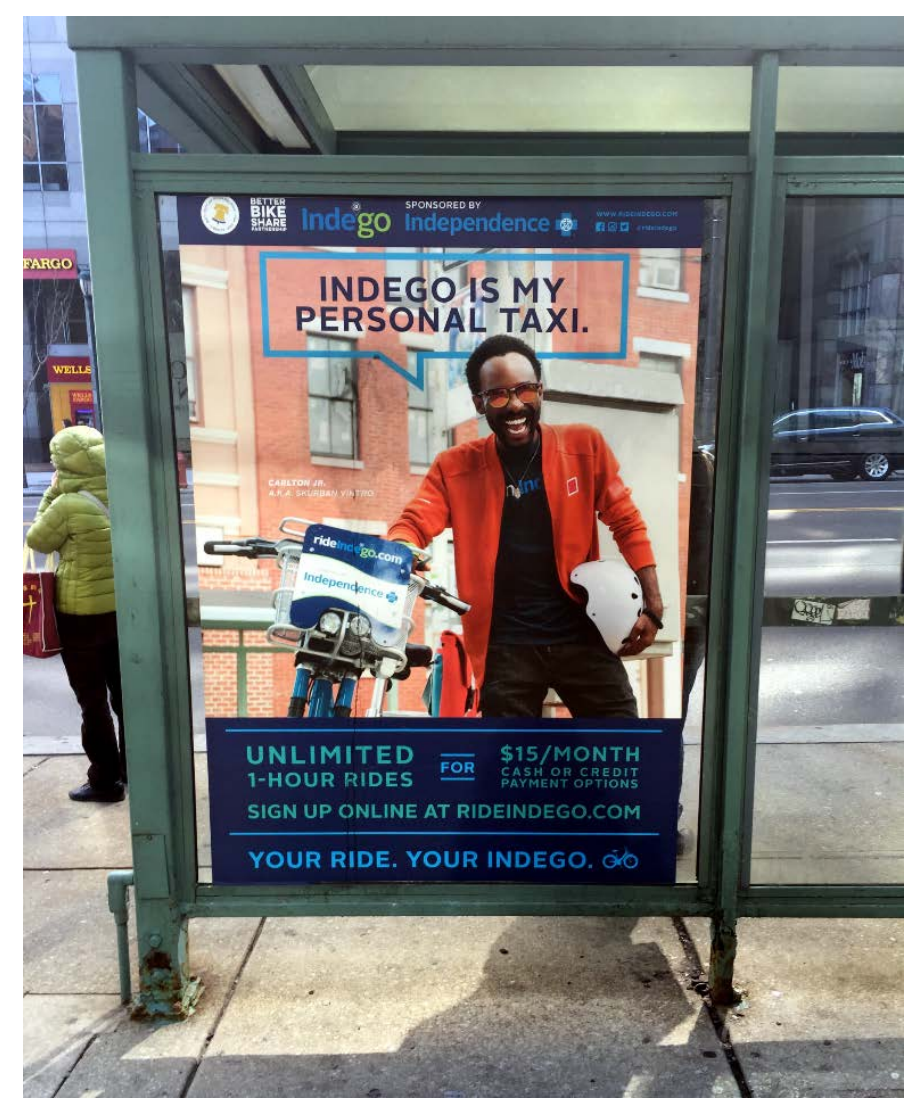

Clockwise from top left: Indego advertisement at bus shelter, contact card handed out at events, and Twitter promotion for member sign up at public Internet location (Keyspot)
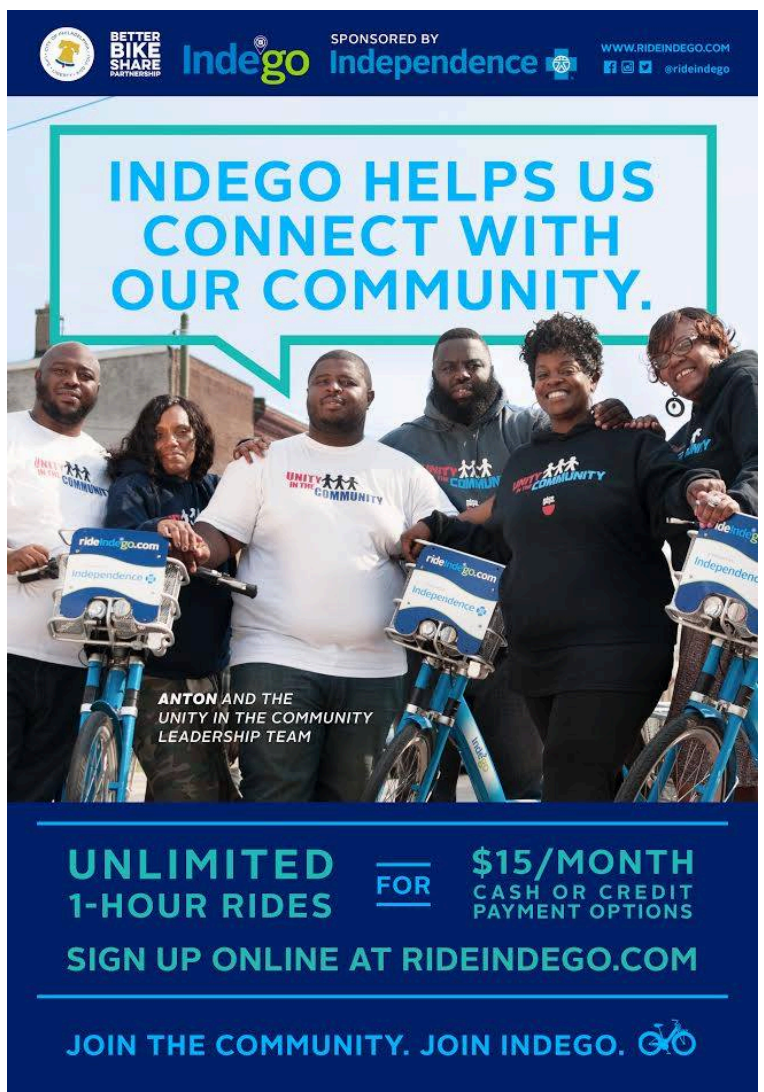

Indego $@$ Ridelndego 22 Sep 2016

Improve your computer skills \& get comfortable biking in the city with Digital Skills \& Bicycle Thrills ow.ly/iPQi304qY9m

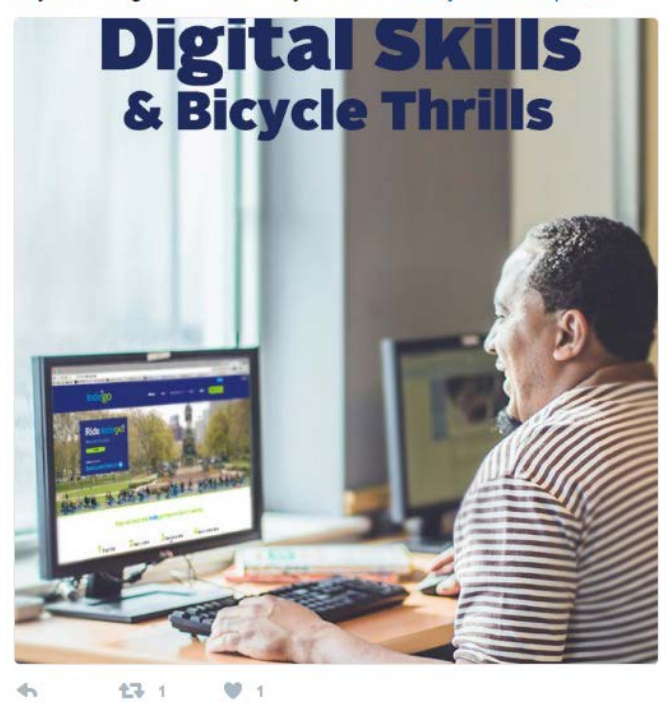

Figure 2-3 Philadelphia's BBSP outreach included a media and education campaign targeted to underserved populations.

Data collection and research. Local BBSP-related research and data collection was conducted by Temple University. Focus groups were held and summarized before Indego's launch, and two 
follow-up intercept studies were undertaken to better understand the distribution of system knowledge and persistent barriers to use (Hoe 2015a; Hoe 2015b; Hoe and Kaloustian 2014). Additional related research was being done at Drexel University, focusing on longitudinal health outcomes of Indego.

\section{$2.3 \quad$ BROOKLYN}

\subsubsection{System: Citi Bike}

Citi Bike launched in May 2013 in New York City with 6,000 bikes and 330 stations. The New York City Department of Transportation (NYC DOT) planned the system, which uses PBSC bicycles and is operated by Motivate (formerly Alta Bicycle Share). A community-driven planning effort had selected 600 station locations, including 36 covering the western and central portions of the Bedford-Stuyvesant (Bed-Stuy) neighborhood in Brooklyn. The development of the system up to the point of our survey is shown in Figure 2-4. Prior to the system launch, the storm surge from Hurricane Sandy inundated the warehouse in which many Citi Bike bikes were being stored. Due to the resulting damage and other operator issues, the system launch was delayed and the number of bikes and stations was reduced from the initial plan. Only 10 of the planned Bed-Stuy stations opened at launch, and they were in the wealthier western portion of the neighborhood that is contiguous with the rest of the bike share system. In August 2015, the remaining stations opened as part of the first Citi Bike expansion, completing the bike share network as originally planned. As of December 2016, the system had over 600 active stations and 9,400 bikes, making it the largest public bike share system in the U.S. Before the expansion, a partnership formed among several local agencies, coordinated by the Bedford-Stuyvesant Restoration Corporation (BSRC), to focus on equity outcomes at the new stations in Bed-Stuy.

Pass and use options. At launch, Citi Bike offered $\$ 95$ annual memberships along with daily and weekly passes. Current offerings include an annual membership for $\$ 163$, or for $\$ 14.95$ per month with an annual commitment (\$179.40 per year), along with daily and three-day passes. Annual members receive unlimited 45-minute rides, while daily and three-day memberships are limited to 30-minute rides before extra charges accrue.

New York City Housing Authority (NYCHA) (public housing) residents and members of select Community Development Credit Unions are eligible for discounted memberships of \$5 per month (with an annual commitment). Some other discounts are available, including a first-year $15 \%$ discount for IDNYC (city issued government ID available to anyone age 14 or older) cardholders, and a $10 \%$ discount for holders of Citibank credit or debit cards. 

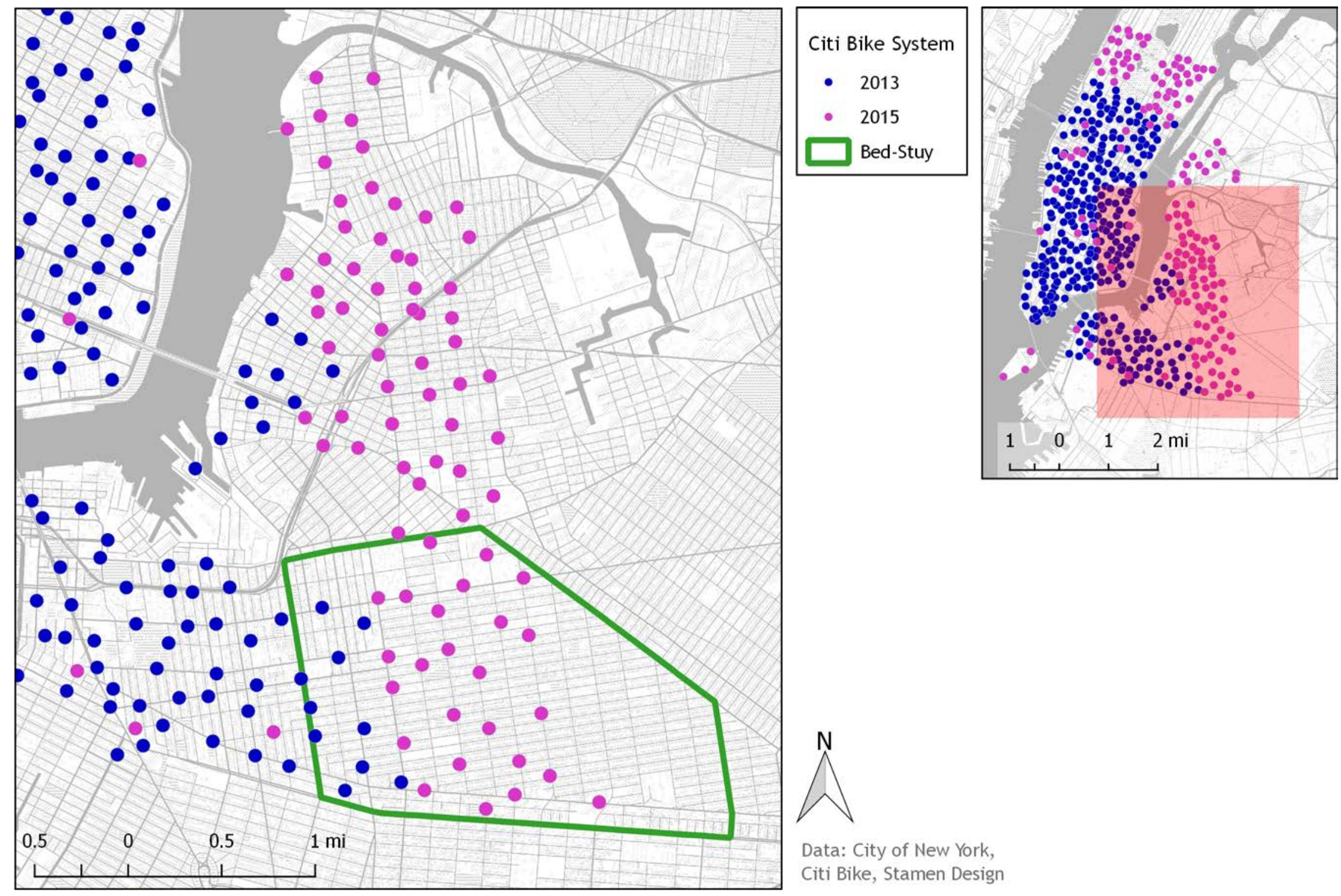

Figure 2-4 Citi Bike bike share system development from launch through July 2016.

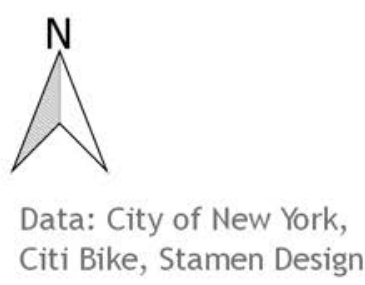




\subsubsection{Equity initiative}

Bedford-Stuyvesant (Bed-Stuy) is a majority Black neighborhood in Brooklyn with relatively high levels of poverty and a high concentration of public housing. Although it was originally slated to be included in the Citi Bike system at launch, various delays slowed Citi Bike’s arrival in much of the neighborhood for two years.

With the plan to expand further into (Bed-Stuy in 2015, NYC DOT; NYC Department of Health and Mental Hygiene (DOHMH); the Bedford-Stuyvesant Restoration Corporation (BSRC), a community development organization; and Citi Bike sought to ensure that the system provided a benefit and value to all residents, including lower-income and residents of color.

BSRC noted three key barriers to Citi Bike use by community residents. First, there were initially only 10 stations in the neighborhood, clustered around its western (and more affluent) edge. Most of the neighborhood, and the vast majority of lower-income residents, did not have bike share stations nearby. Second, the cost of bike share (\$149 per year at the time) represented a significant financial outlay for Bed-Stuy's many lower-income residents, and many were not aware of discounted membership options through NYCHA and credit unions. Finally, community perceptions of bicycling were thought also to play a deterring role. These included perceptions that biking on Brooklyn streets was not safe or easy, and that increases in bicycling might come at the expense of other modes of transportation as bikes competed for space with public transit, motor vehicles and pedestrians. BSRC also noted that many residents view bike lanes and cyclists as a sign of gentrification. Efforts were made to address each of these barriers, as detailed below.

Bike share stations in low-income communities. As discussed above, 26 new Citi Bike stations were added in Bed-Stuy in August 2015, bringing the total number of stations in the area to 36 and extending the coverage area to the majority of the neighborhood. While the stations were not planned or funded as part of a specific equity policy, the areas served are considerably more diverse and farther from Manhattan than the initial service areas.

Discounted membership option promotion. BSRC has worked to raise awareness among BedStuy residents about discounted Citi Bike options for NYCHA residents and for Brooklyn Cooperative Federal Credit Union members. BSRC specifically targeted public housing residents, located mainly in the northern half of the neighborhood, for tailored outreach. This included setting up individual meetings to help residents understand how to enroll in the discount programs and how to use the system.

General outreach efforts. BSRC sought to educate Bed-Stuy residents about bicycling in general, and about signing up for and participating in Citi Bike specifically. Outreach efforts included hosting major outreach events for public housing and community residents in June and August, and attending community events to demonstrate the Citi Bike bicycles and offer test rides, helmet fittings, member sign-ups and free day passes, among other activities. Classes were offered to learn to ride a bike, and group rides and riding safety workshops were also made 
available. Generally, organized bike rides took place on a biweekly basis. BSRC efforts were led by a project manager, and coordinated in partnership with NYC DOT and Citi Bike.

BSRC assembled a team of Community Outreach Ambassadors, who generally were residents of Bed-Stuy and surrounding communities, aged 21 or younger, and hired over the summer through a summer youth employment program. BSRC specifically targeted NYCHA residents to join the Ambassadors. The Ambassadors attended many of the outreach events, and assisted with data collection for a neighborhood intercept survey to better understand barriers to bike share use. They also served to generally broadcast the message of bike share throughout the community.

BSRC and its partners also provide a variety of other services to Bed-Stuy residents, and looked for opportunities to connect their clients to bike share. Integration of Citi Bike information into financial counseling services was viewed as one way to take advantage of services already being provided by BSRC. Ambassadors also played a role in these efforts, educating people on the potential financial benefits of bike share, including saving on transit or taxi costs, and enrolling people at locations including the Brooklyn Cooperative Federal Credit Union.

Outreach marketing materials were tailored to the community in hopes of addressing persistent myths that the bikes were not intended for everyone. This included producing brochures and posters that showed people of color and members of the community. Advertisements were placed on bus shelters, in community newspapers and in other forms of media (Figure 2-5).

BSRC, working with the NYC Department of Health and Mental Hygiene (DOHMH), also developed connections to two medical centers - Woodhull Medical Center and Interfaith Medical -for a prescribe-a-bike program. Between 2015 and 2016, 148 individuals were "prescribed" a subsidized bike share membership (at no cost to the patient). 


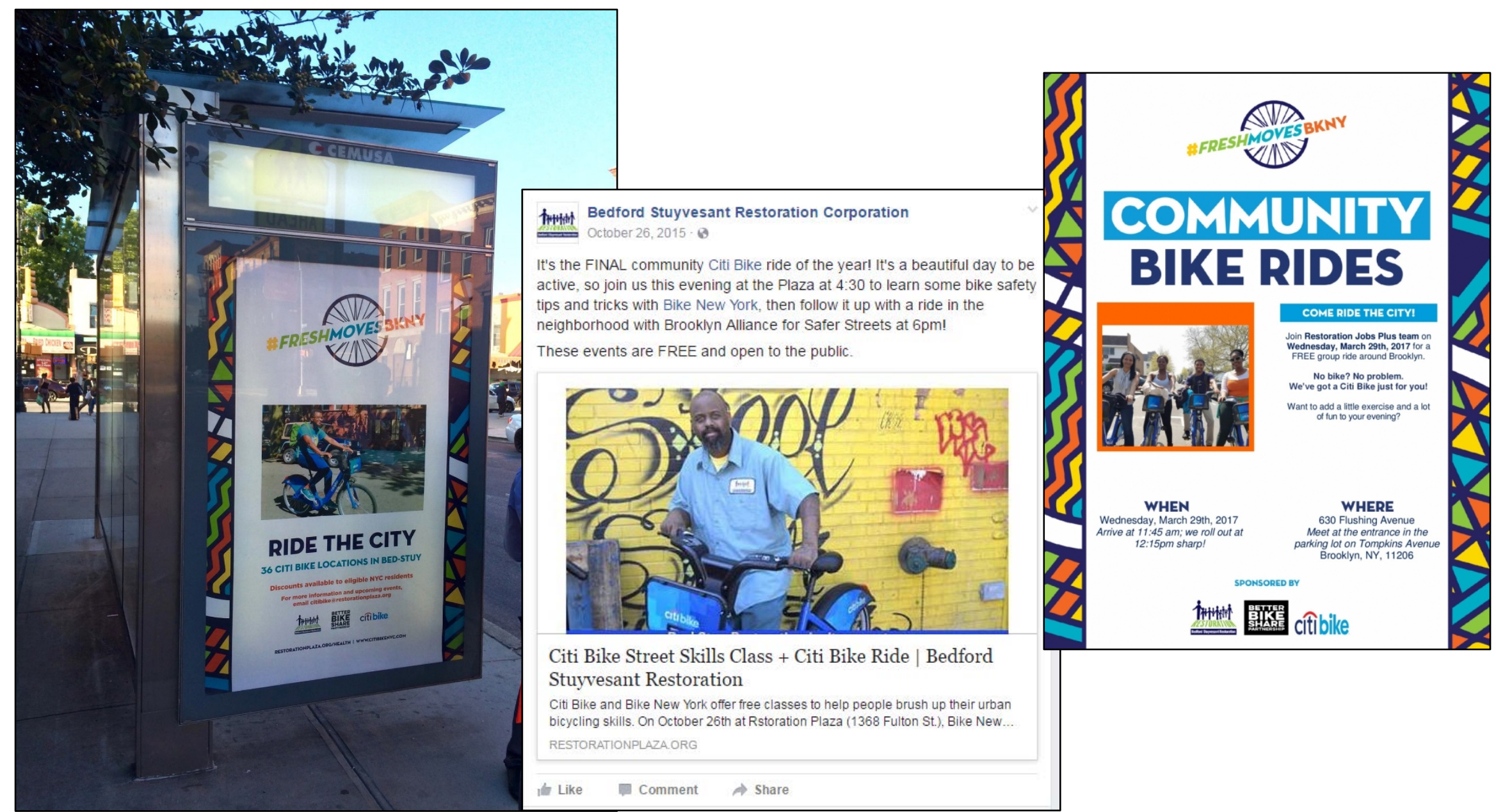

Figure 2-5 Brooklyn targeted outreach media (left to right): bus shelter advertisement, Facebook promotion for Skills Class and Citi Bike Ride, community bike rides event flyer. 
Data collection and research. DOHMH conducted focus groups with 30 Bed-Stuy residents in 2015. In addition, BSRC, in partnership with the DOHMH, conducted an intercept survey of Bed-Stuy residents. This survey captured basic data on use of and barriers to use of bike share from 230 residents in summer 2015.

BSRC and NACTO (2017) reported on station use and the activities of BSRC during the expansion of Citi Bike in Bed-Stuy. Success stories noted included large numbers of participants in BBSP-related events: all events (2,500), group rides (450 on 84 rides), stakeholder trainings and meetings (nearly 200). The report highlights a substantial one-year increase in Citi Bike trips in Bedford-Stuyvesant with the additional 26 stations in operation, and ridership growth above the citywide average. In addition, Bed-Stuy experienced increases in Citi Bike membership at a faster rate (56\%) than the city as a whole (46\%) from March 2015 to December 2016. NYCHA resident enrollment also grew faster than in the city overall.

\subsection{CHICAGO}

\subsubsection{System: Divvy}

The development of the Divvy system up to the point of our survey is shown in Figure 2-6. Divvy launched in June 2013 in Chicago with about 70 stations. Supplier issues slowed plans to expand, but the system grew to about 300 stations by fall 2013, and the initial buildout of 475 stations was completed two summers later, in 2015. Beginning in 2016, the system also operated in two nearby cities, Oak Park and Evanston. By January 2017, there were 580 stations and 6,000 bicycles. A community-driven planning effort had suggested many of the station locations. The Chicago Department of Transportation (CDOT) formed a partnership with other local organizations to participate in the BBSP program with both citywide and neighborhood-level components. The Divvy system and equipment are owned by the City of Chicago. The equipment is manufactured by PBSC and the system is operated by a subsidiary of Motivate International LLC. CDOT secured matching funds from Blue Cross and Blue Shield of Illinois, Divvy’s system sponsor.

Payment options include an annual membership (which cost $\$ 75$ per year at launch, and is now $\$ 99$ per year, or $\$ 9.95$ per month with an annual commitment) and a walk-up day pass for \$9.95 (\$7 at launch).

\subsubsection{Equity initiative}

CDOT served as the lead on the Chicago BBSP initiative. The initiative was undertaken as a multi-tiered approach to address a number of perceived barriers, both in a specific neighborhood (Bronzeville, discussed below) and citywide. In its BBSP application, CDOT noted that white residents were dramatically overrepresented among Divvy riders compared to the overall population. CDOT and its local partners suggested that key reasons were cost, awareness, and general perceptions of bike share specifically and bicycling in general. 
Potential solutions identified included: placing stations in neighborhoods with higher shares of residents of color and in other underserved communities; conducting outreach in those communities to raise awareness about bike share and the viability of biking as a form of transportation; and addressing cost and payment barriers associated with joining Divvy.

Bike share stations in low-income communities. There were Divvy stations throughout the Bronzeville neighborhood at launch, including one directly in front of the Cara Center, a Local Initiatives Support Coalition (LISC) Financial Opportunity Center (see below for more detail on LISC and FOCs) participating in the Divvy for Everyone (D4E) program. Additional stations were added in spring 2015 and have continued to expand after this survey was completed, especially in areas south and west of the study areas 


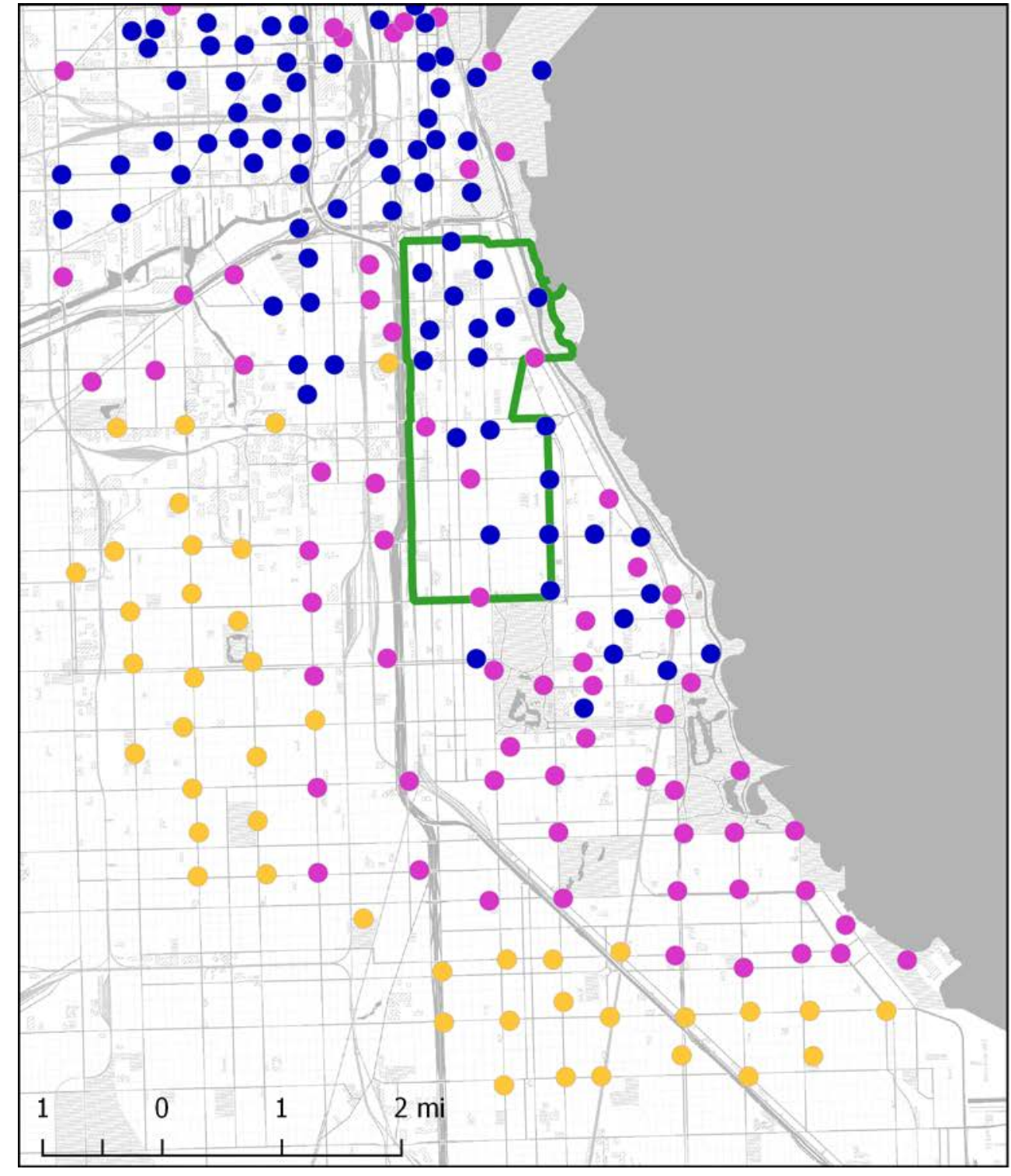

Figure 2-6 Divvy bike share system development from launch through July 2016.
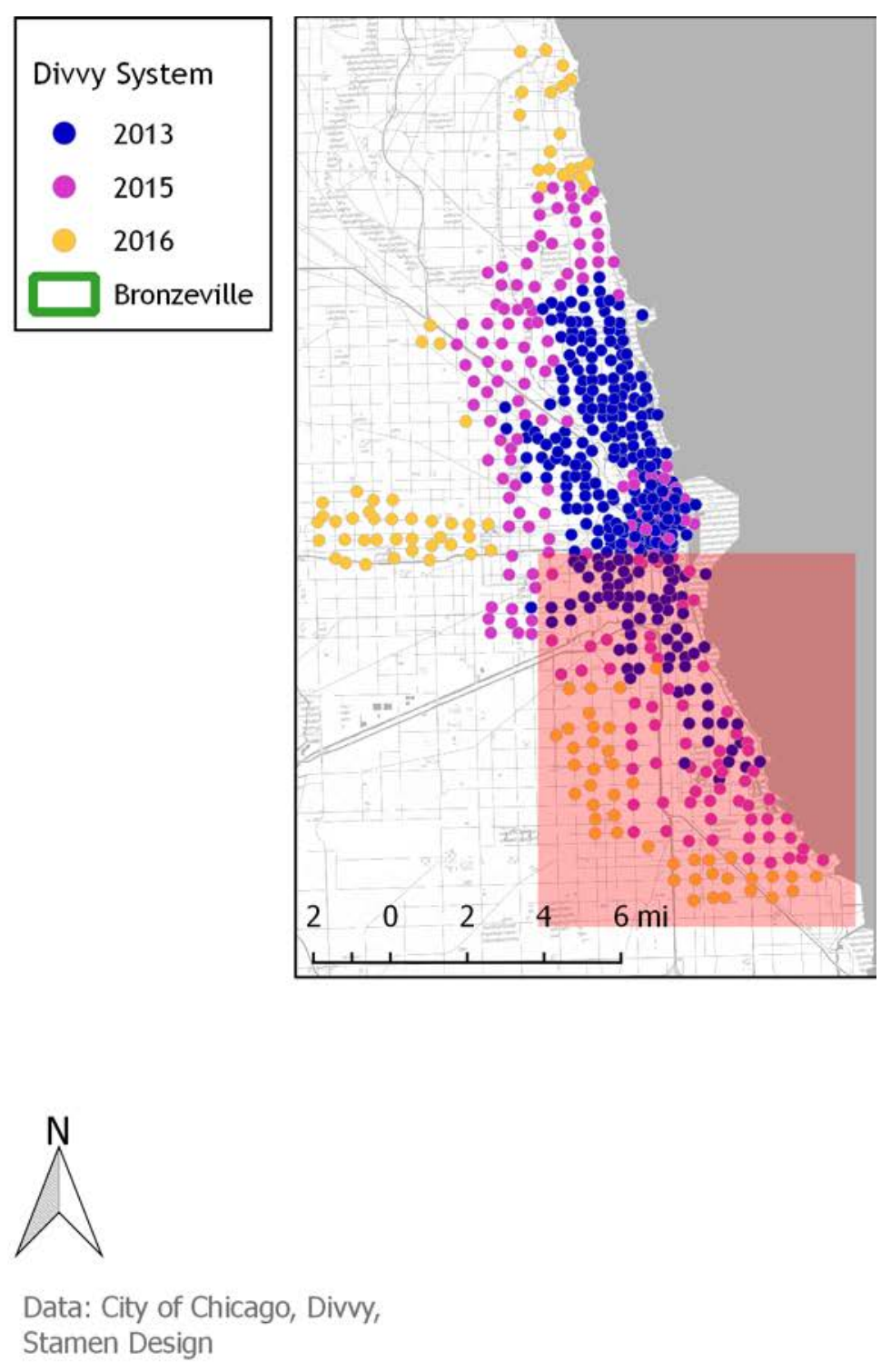

Stamen Design 
Discounted membership options. Divvy's primary citywide equity effort is centered around D4E, which offers a \$5 first-year membership to enrollees, a significant discount from full price, and accepts cash payments. The program is open to Chicago households making $300 \%$ or less of the federal poverty guideline (approximately \$35,000 annual income for a one-person household, $\$ 48,000$ for two, $\$ 60,000$ for three, $\$ 72,000$ for four, and so on). Divvy subsequently created an ongoing membership plan for D4E members continuing in year two, which included an annual membership at \$50 per year (half the full price) or \$5 per month (\$60 per year total), then transitioning to a full cost membership in year three.

Divvy partnered with LISC Chicago to administer the D4E program. Among other programs, LISC Chicago operates 12 FOCs around Chicago where residents can go for assistance in employment and personal finance. CDOT identified five centers in the 2015 Divvy expansion areas to process D4E applications. A dedicated staff member at each FOC was trained to evaluate and process D4E applications, accept payment from enrollees (including cash), help with activation, and provide information about bicycling, including maps and safety information. It is a “one-stop” process, and qualified applicants can ride away on a Divvy bike. They have also worked to clarify any overage charges for trips over 30 minutes so that new members are not surprised by charges. Participating FOC locations are identified on the D4E website and dedicate specific hours to handling membership inquiries. A sixth FOC location has been added to the D4E network as the system has expanded. Although they provide information about Divvy and the D4E program to existing clients, the vast majority of sign-ups have been first-time visitors to the FOCs, coming only to enroll as bike share members. The FOCs see particular value in then connecting these people to health, transit and information about the wider suite of services they offer the community. They have also expanded their credit-building program, Twin Accounts, to include D4E renewal payments.

D4E outreach and promotion benefited from considerable coverage by major media news outlets (Figure 2-7). Mayor Rahm Emanuel attended the D4E program’s launch, which led to considerable press coverage. Enrollments started July 7, 2015. Although CDOT had a goal of 750 sign-ups in year one, it received over 650 sign-ups in the first month and over 1,000 before the winter season. CDOT estimates that $80 \%$ of D4E members had used the system as of March 2016. A loss liability fund was established to protect against lost or damaged bikes, but this has not been a problem for the D4E program in practice.

General outreach efforts. Chicago's BBSP-related outreach efforts around bike share included citywide outreach in partnership with Slow Roll Chicago and CDOT's Bicycling Ambassadors outreach and education team, and targeted outreach in the system expansion neighborhood of Bronzeville on the South Side, in partnership with Go Bronzeville.

Slow Roll Chicago is a nonprofit community organization that promotes quality of life through bicycling in communities of color and low- to middle-income neighborhoods throughout Chicago. Slow Roll's primary BBSP outreach consisted of promoting and hosting rides citywide. Slow Roll hosts rides every Wednesday during nice weather, and on some Saturdays. Rides are often based around a community theme such as neighborhood music, gardens, history or art. Many rides start and stop near Divvy stations to allow people to use bike share bikes, and rides 
frequently have as many as 100 riders and 10 to 12 leaders. One important mechanism of promotion was to use Slow Roll's popular weekly calendar of bike- related events.

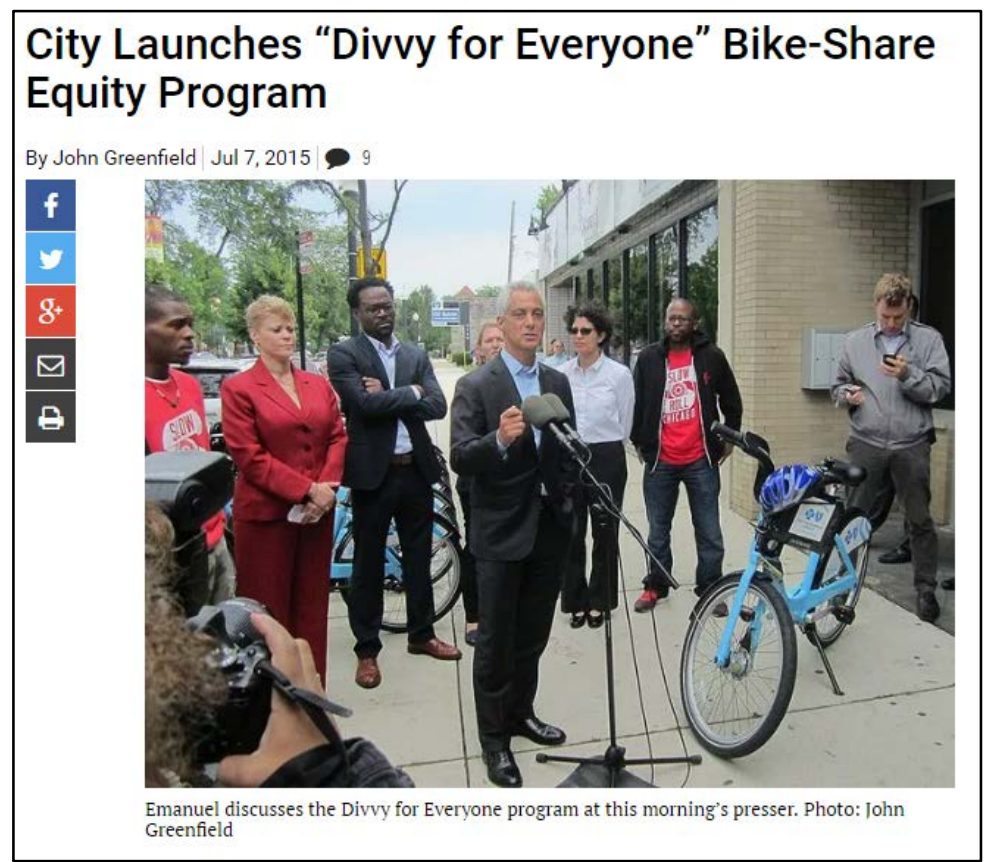

\section{SUNFTIMES}

News

Low-income Chicagoans eligible for $\$ 5$ annual Divvy memberships CHICAGO NEWS 07/107/2015, 10:27am

Jordan Owen

@byjordanowen | email

Sign-Up for our Ne Newsletter

Mayor Emanuel announced a "Divvy for Everyone Tuesday morning, allowing Chicago residents wit affordable access to the popular bike-share progr

Above: chi.streetsblog.org

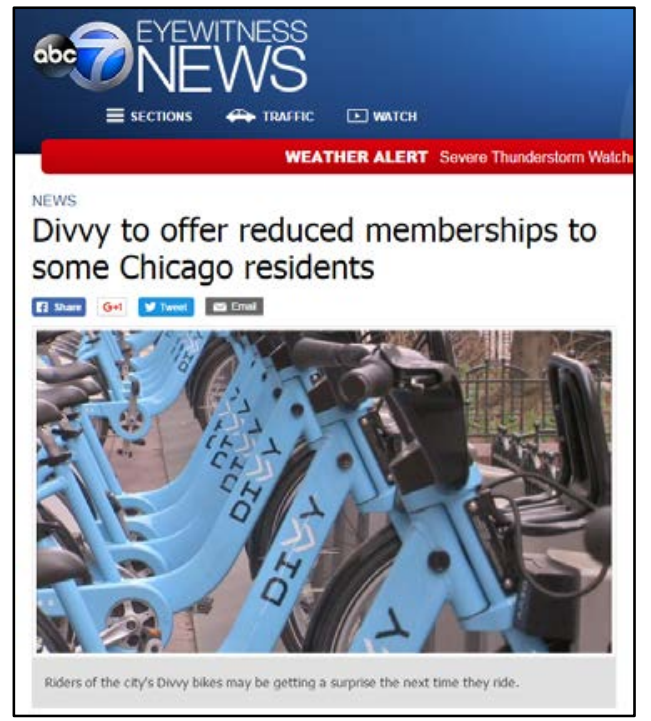

\section{Chicagn đribume}

One-year Divvy discount coming for low-income Chicagoans

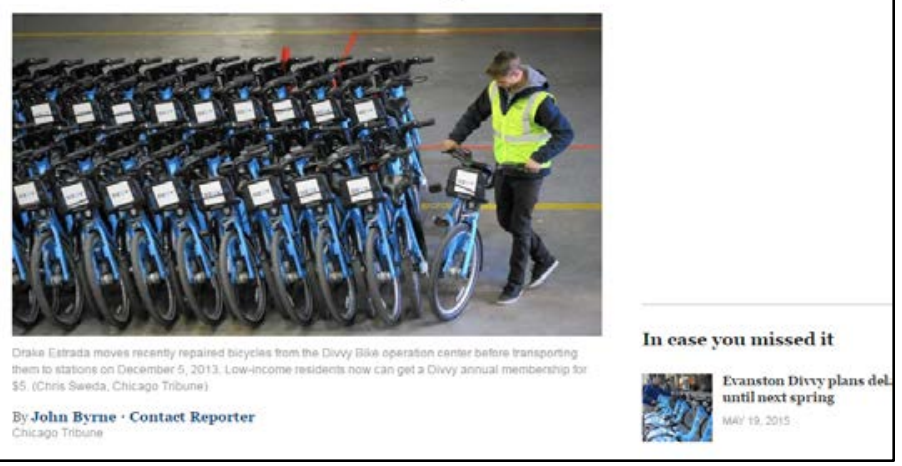

Figure 2-7 Divvy for Everyone outreach included major media coverage, including a speech by the mayor at a launch event in Bronzeville.

Go Bronzeville began as a City of Chicago transportation demand management (TDM) program in 2013. In the subsequent years, local volunteers took over running the program to further the cause of promoting local transportation options including bicycling in the Bronzeville neighborhood. Go Bronzeville has a team of outreach specialists focused on the D4E's “deepdive” education and outreach pilot program. Go Bronzeville’s team consisted of an outreach 
manager, a well-connected community member, and an ambassador who often leads Slow Roll rides in Bronzeville along with conducting other outreach. The community rides, along with Go Bronzeville's presence at events and broader work in the community, were the primary outreach strategies. Typically, two to three ride participants used Divvy bikes on the neighborhood rides.

Between July 2015 and October 2016, Slow Roll reported conducting 89 events with over 3,500 participants, while Go Bronzeville reported 36 events with over 1,500 participants. Though outreach was planned to coordinate with the launch of D4E in July, most happened in fall and winter due to contracting delays.

Data collection and research. CDOT tracked and analyzed D4E membership and use data to inform and evaluate outreach efforts. Participating FOC sign-up centers gathered data on new members. The Illinois Institute of Technology (IIT) Institute of Design led a graduate workshop on the adoption of bike share on the South Side. The students planned to use secondary data, surveys and ethnographic techniques to better understand barriers and motivators of bike share use. 


\subsection{METHODOLOGY}

The user survey was developed to extend upon the findings of the resident survey (covered in report NITCN-RR-884b). The resident survey captured views and experiences with bicycling and bike share among the general target communities. However, because the percentage of randomly sampled residents who had actually used bike share was low, a separate survey was developed to better understand current and past users of bike share who the BBSP programs were intended to serve. Generally, this included bike share members living within the resident survey neighborhoods, people who received BBSP-related outreach (whether or not they became a bike share member), and current and past members who had taken advantage of BBSP-related discount or cash payment programs.

The survey instrument was adapted from the resident survey, with several consistent sections to allow for comparison. Several additional sections, as described below, were added to better understand when and how people were using bike share and what if any benefits they were experiencing. All survey invitations were sent out via email from either the bike share operators or city partners, with text from both the sender and the research team describing the survey.

\subsection{SURVEY INSTRUMENT}

The surveys were generally identical between the three cities, with only minor modifications based on the city. Each city's survey specified the name of the local bike share system (Indego in Philadelphia, Divvy in Chicago and Citi Bike in Brooklyn) each time the system was asked about. A copy of one of the surveys is in Appendix A.

Specific sections included in the survey were:

- General questions about their neighborhood and how they get around.

- Information on what residents think about the bike share system, including reasons they might be interested in using bike share, measures that might make them more likely to use bike share, and barriers to using the system.

- General questions about residents' experience with the bike share system, including a brief description of the system providing the name; a photo of one of the bike share bikes; and the statement that people can check out a bike from any station, ride it, and return it to any other station.

- Questions about the respondent's use of bike share.

- Questions about membership options and payment.

- Rating 16 potential barriers to using the bike share system as not a barrier, small barrier or big barrier, with a does-not-apply option. There is a space to specify in writing the most important barrier as well.

- Questions about bicycling in general.

- The final section of the survey pertains to information about the respondent and their household, including demographic questions. 
The survey was created as an online survey using a Portland State University (PSU) subscription to Qualtrics. The online survey allowed us to limit the questions shown to the respondent to only those that applied based on their earlier responses, and therefore could streamline the survey process somewhat. For example, only those respondents who indicated that they were no longer members were asked why they had stopped being members.

Online surveys are often not recommended as the sole option when surveying lower-income populations, who generally have lower rates of access to reliable internet service. However, we chose this method for several reasons. Nearly all bike share members (regardless of income) use the internet to join the system and manage their memberships, and email is a primary means of communication between the operators and their customers. It was the most cost-effective method of reaching these users, given our research budget. Finally, we would not have been able to obtain mailing addresses or phone numbers for many of the people we wanted to sample, either because of privacy agreements with the bike share operator or that those methods of contact were not collected by the BBSP partners for certain outreach programs. Future studies may consider a mixed method approach incorporating some combination online surveys, mailed paper surveys, intercepts, and surveys by phone or text.

The project team tested the completed survey by having students take the survey and provide feedback, including noting any confusing questions or wording, and recording the time it took to complete. The surveys were also shared with project partners in each city for content-specific feedback.

We elected not to translate the user survey into Spanish after observing that very few resident survey participants had chosen that option $(n=3,0.3 \%)$.

The entire survey process was approved by PSU’s Human Research Subjects Committee.

\subsection{SURVEY IMPLEMENTATION}

The research team worked with the bike share operators and outreach organizations in each city to distribute email invitations for the surveys. The invitation email included a short explanation of the study and survey, and a link to the online survey. The introduction screen for the survey had a more detailed explanation of the survey and the respondents' rights as a research subject, including the right not to participate. Invitees were given about two weeks to complete the survey. A follow-up email and reminder were sent about a week after the original invitation was sent.

In each city, we aimed to survey two groups (Table 3-1). The first were bike share members living in the neighborhoods targeted for outreach and areas used as controls in the resident survey. This was done by selecting invitees based on the ZIP Code they provided when signing up for bike share. As shown in (Table 3-1), the ZIP Code areas were larger than the neighborhoods sampled for the resident survey. Second were people who had taken advantage of an equity-related bike share program, regardless of where they lived. This included people who participated in BBSP partner events (e.g., rides) or other outreach activities, and people who took advantage of an equity-focused discount program (such as the Divvy For Everyone program in 
Chicago, PA Access Indego discount recipients in Philadelphia or cash payment participants in Philadelphia). Due to the large number of discounted Citi Bike members located in the target ZIP Codes, the invitation for those members was not extended citywide. An overview of this sampling frame, including the geographic and other programmatic targets, is included in Table 3-1. More details appear in the following sections.

Table 3-1 Survey invitation targets by city

\begin{tabular}{|c|c|c|}
\hline City & Geographic Targets & Other programmatic targets \\
\hline Philadelphia & $\begin{array}{l}\text { Current or former Indego passholders in ZIP } \\
\text { Codes in the outreach target areas (19121, } \\
\text { 19122, 19123, 19130,19146, 19147, 19145, } \\
\text { and 19104) }\end{array}$ & $\begin{array}{l}\text { Indego30 Access discount passholders } \\
\text { (citywide) } \\
\text { Passholders who have paid with cash } \\
\text { Bicycle Coalition Indego outreach } \\
\text { participants }\end{array}$ \\
\hline Chicago & $\begin{array}{l}\text { Current or former Divvy members in ZIP } \\
\text { Codes in outreach target areas (60653, } \\
60615,60637)\end{array}$ & $\begin{array}{l}\text { Divvy For Everyone (D4E) discount members } \\
\text { citywide } \\
\text { "Free Ride Weekend" participants }\end{array}$ \\
\hline Brooklyn & $\begin{array}{l}\text { Current or former Citi Bike members in ZIP } \\
\text { Codes in outreach target areas }(11211 \text {, } \\
11206,11205,11221,11216,11213,11233 \text {, } \\
\text { and } 11238)\end{array}$ & $\begin{array}{l}\text { None, although the geographic target } \\
\text { included NYCHA and community credit union } \\
\text { discount members. }\end{array}$ \\
\hline
\end{tabular}

Respondents who completed the survey were able to enter a drawing for a \$250 Amazon gift card (one per city). In addition, 20 to 35 other respondents (depending on the city) received compensation worth around \$5 (either a gift card to a local merchant, or 2-3 transit passes or tokens) as an "early bird” bonus. 


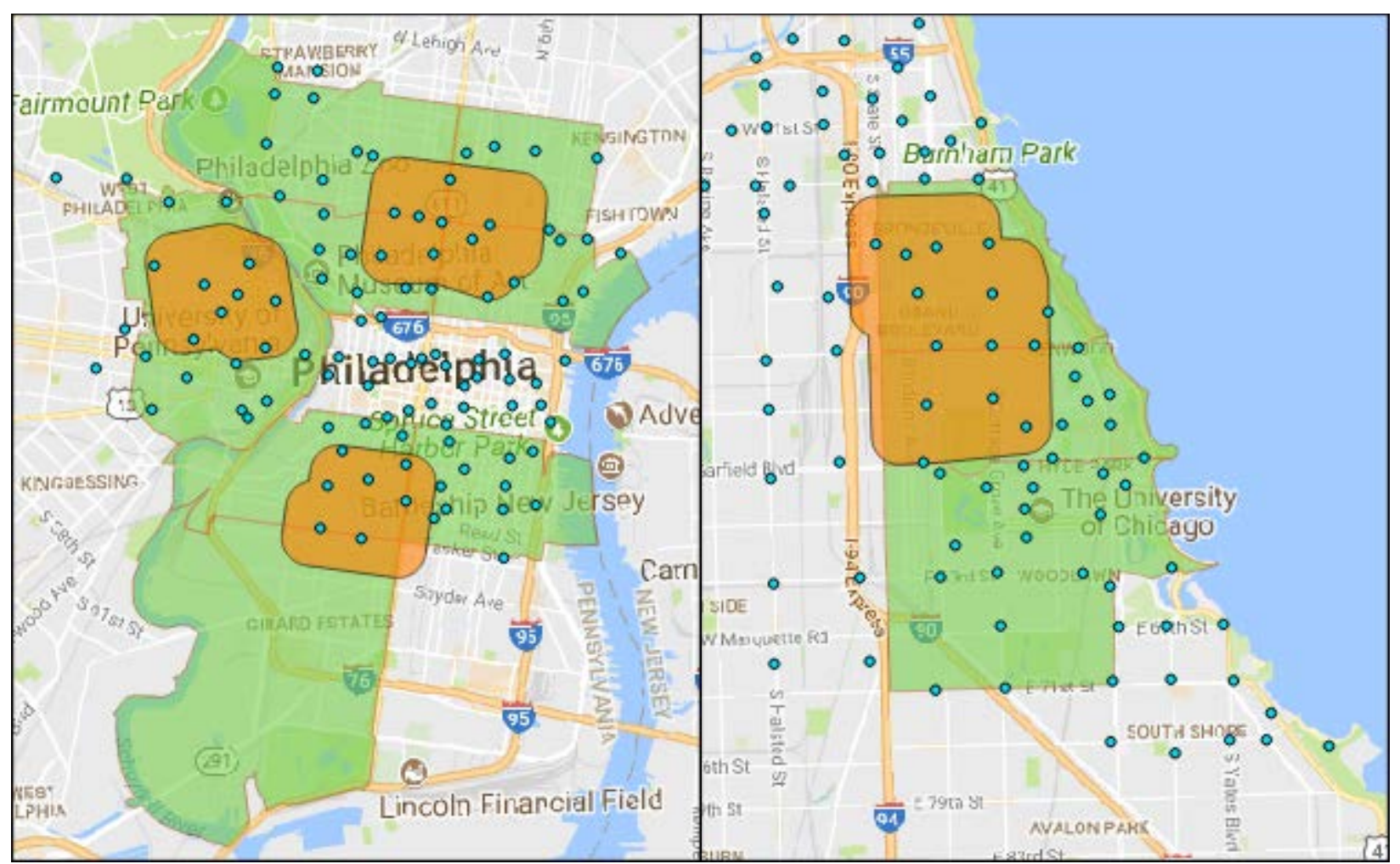

\section{Philadelphia}

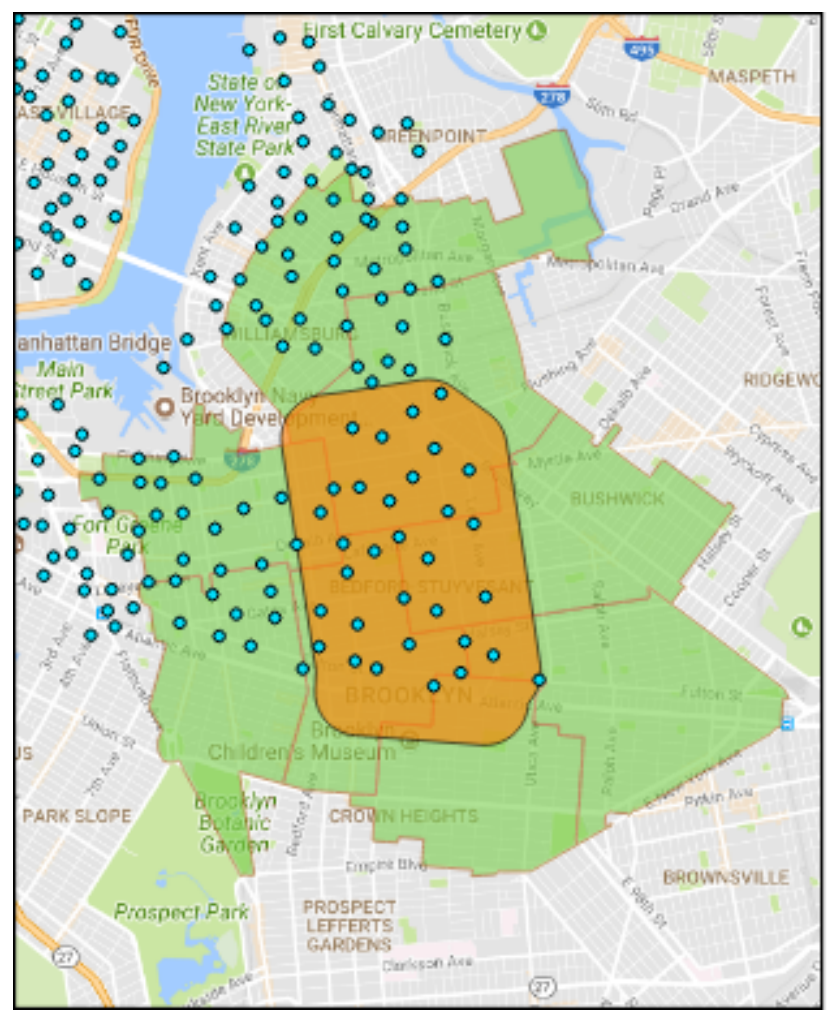

Brooklyn

\section{Chicago}

- Bike share station

BBSP outre ach study area

User survey Zip code area

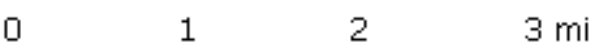

Data sources: Indego, Diwy, Citi Bike, Census TIGER/Line, Google Maps

Figure 3-1 User survey sampling areas. 


\subsubsection{Philadelphia}

In Philadelphia, Indego operator Bicycle Transit Systems sent an invitation to approximately 1,195 individuals, including PA Access members, cash members, members in the target ZIP Codes (19121, 19122, 19123, 19130, 19146, 19147, 19145 and 19104), and outreach participants. The original invite was sent March 28, 2017, with a deadline of April 14, 2017. A reminder email was sent on April 6. The Indego survey was mailed later than the surveys for the other two cities to avoid conflicting with the annual fall member survey. A screen shot of the invitation email is shown in Figure 3-2.

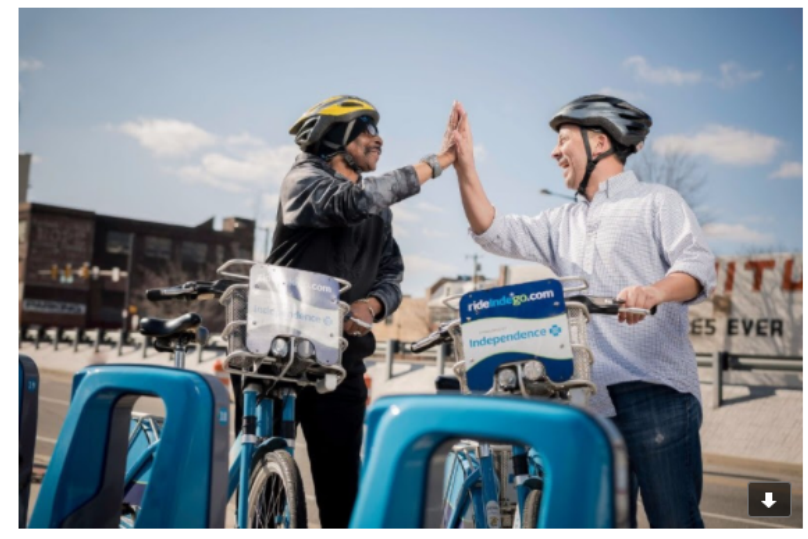

A Message from Indego

Dear Indego Supporter,

We can't thank you enough for choosing Indego as one of your preferred methods for transportation and recreation. In just two years, we've been able to accomplish a lot of milestones - like reaching one million rides - thanks to you!

We are partnering with Portland State University on a national study of bike share in cities. They are inviting YOU to participate by taking an online survey. Details about their study and survey are included below.

Please note: Indego is NOT conducting this survey - questions about the survey or study should be directed to the researchers at Portland State University (see contact information below).

Thank you for your continuous support.

Team Indego

\section{TAKE SURVEY}

\begin{abstract}
About the Survey
The Transportation Research and Education Center at Portland State University is conducting an important national study about how (or if) you use bike share, and how it can better serve you and a variety of communities.

The survey should only take 15-25 minutes to complete and you must be 18 or older to participate. Your responses will be completely confidential and it will not be possible to tell who said what in any reports - we do not anticipate any risk to you in answering the survey. If you have any questions about the study, please contact streets@pdx.edu or $\underline{503-725-2875}$.
\end{abstract}

Anyone who returns their survey by April 14th will be entered into a drawing for a gift card to Amazon.com (in the amount of \$250) OR one of 35 additional prizes.

To learn more about the survey, please click here.

This research can only be successful with the generous help of people like you. We hope you will enjoy answering our questions and we look forward to receiving your responses.

Many thanks,

Nathan McNeil

Transportation Research and Education Center

Portland State University

TAKE SURVEY

Figure 3-2 Survey invitation in Philadelphia.

\subsubsection{Chicago}

In Chicago, Divvy invited any current or former Divvy members in 60653, 60615 and 60637, current or former Divvy for Everyone discount program members throughout Chicago, and "free ride weekend” outreach participants. An initial invitation was sent on November 17, 2016, to 
6,336 people. A reminder was send December 5, and respondents were given a deadline of December 9. A mockup of the invitation email is shown in Figure 3-3.

Subject: Take a brief survey to improve bike share

Hi [name],

We are partnering with Portland State University on a national study of bike share in cities. Whether you are a current or former Divvy member, they ask Chicagoans to share how you use bike share, and how it can better serve you.

The survey should take 15-25 minutes to complete. You must be 18 years or older to participate, and your responses will be completely confidential.

\section{Click here to take the survey.}

All riders who complete the survey by November 30,2016 will be entered into a drawing for a $\$ 250$ gift card to Amazon. Additionally, the first 20 people who respond will receive two free single-ride CTA tickets.

This research depends upon the generous help of people like you. We hope you will enjoy answering these questions and we look forward to receiving your responses. If you have any questions about the study, please contact the team by email at streets@pdx.edu.

\section{- The Divvy Team and the Chicago Department of Transportation}

Figure 3-3 Mockup of Divvy survey invitation email.

\subsubsection{New York/Brooklyn}

In Brooklyn, Citi Bike emailed 7,903 current and former Citi Bike members in ZIP Codes that were completely or partially in the Bedford-Stuyvesant neighborhood (ZIP Codes 11211, 11206, 11205, 11221, 11216, 11213 and 11233). This sample included discount program members receiving the \$5 per month or \$50 per year pricing through the New York City Housing Authority (NYCHA) or through a local community credit union. The initial invitation was emailed November 15, 2016, with a reminder on November 29, 2016, and completion date of December 2, 2016. A mockup of the invitation email is shown in Figure 3-4.

In addition to the Citi Bike email, the Bedford-Stuyvesant Restoration Corp. (BSRC) sent an email to a list of community members who had participated in their bike share outreach in some way - either through going on an organized bike ride, through one of their prescribe-a-bike partnerships in the community, or other outreach events. Approximately 600 people received an email invitation from BSRC on December 14, 2006, with a completion deadline of December 30. 


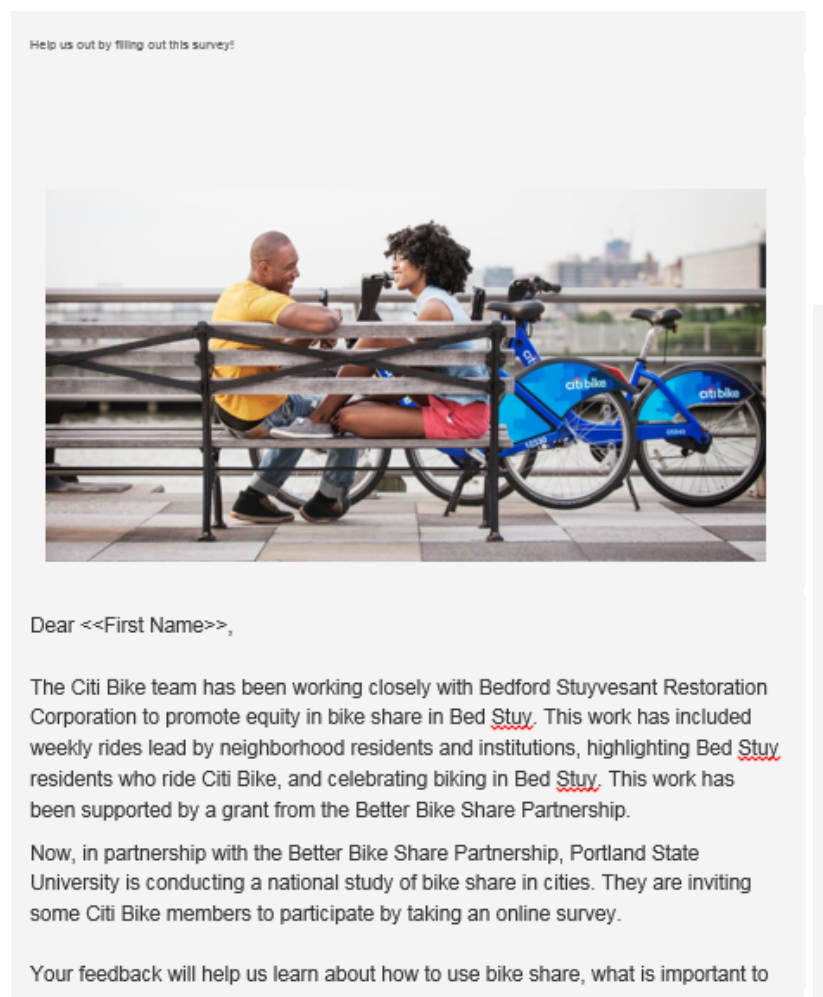

you, and how services like this can better serve your community. The survey is being conducted in several cities around the country.

\section{Start the Survey Now}

The survey should take 10-15 minutes, and you must be 18 or older to participate. You do not have to participate, and you can skip any questions you do not want to answer. Your responses will be completely confidential, we are not tracking who said what. PSU is conducting the research and will report their findings back to us.

All people who complete the survey by December 2, 2016 will be entered into a drawing for a gift card to Amazon.com (in the amount of \$250). Further, the first 25 people who respond will receive a free 2-ride Metrocard from PSU.

This research can only be a success with the generous help of people like you. We look forward to receiving your responses.

If you have any questions about the study, please contact the research team directly at streets@pdx.edu or 503-725-2875. This research is sponsored by the U.S. Department of Transportation through the National Institute for Transportation and Communities, and by the Better Bike Share Partnership

\section{Figure 3-4 Citi Bike survey invitation email.}

\subsection{RESPONSE RATES}

The total number of people invited to take the survey in each city, along with the number of people who clicked on the survey link or provided a partial response and the number of people who completed the survey, are shown in Table 3-2. We received a much higher response rate in Brooklyn/New York than in other cities.

Table 3-2 Response rates

\begin{tabular}{|l|c|c|c|c|}
\hline \multicolumn{1}{|c|}{ City } & $\begin{array}{c}\text { Participants } \\
\text { Invited }\end{array}$ & $\begin{array}{c}\text { Click-through or } \\
\text { Partially }\end{array}$ & $\begin{array}{c}\text { Completed } \\
\text { Survey }\end{array}$ & $\begin{array}{c}\text { Response } \\
\text { Rate }\end{array}$ \\
\hline Philadelphia & 1,195 & 71 & 38 & $3 \%$ \\
\hline Chicago & 6,336 & 342 & 234 & $4 \%$ \\
\hline New York & 8,503 & 1,172 & 820 & $10 \%$ \\
\hline Total & 16,034 & 1,585 & 1,092 & $7 \%$ \\
\hline
\end{tabular}

Table 3-3 shows the correspondence between user-provided home Zip codes and our target Zip codes. About 22\% of respondents fell outside of our target neighborhood areas. The majority of those had participated in citywide BBSP discount programs or other outreach. The remainder may have moved since joining bike share. 
Table 3-3 Correspondence with target Zip Code areas

\begin{tabular}{|c|c|c|}
\hline \multirow[b]{2}{*}{ City } & \multicolumn{2}{|c|}{ Based on Provided Zip Code ${ }^{1}$} \\
\hline & $\begin{array}{c}\text { Within User } \\
\text { Sampling Zip code }\end{array}$ & $\begin{array}{c}\text { Outside User } \\
\text { Sampling Zip Codes }\end{array}$ \\
\hline Philadelphia & 33 & 25 \\
\hline Chicago & 95 & 246 \\
\hline New York & 1099 & 70 \\
\hline Total & 1227 & 341 \\
\hline
\end{tabular}

${ }^{1}$ includes partial responses

We also asked participants to provide cross streets of the nearest intersection to their home. Where these were provided, we geocoded the locations to compare with our resident survey study areas. While we were limited to Zip Code-matching to recruit bike share users, we hoped to capture some respondents living in the same BBSP outreach areas that we defined in our previous survey of residents. We considered all those providing an intersection falling within a quarter-mile of our defined BBSP outreach areas to overlap with those areas. The quarter-mile buffer accounts for the spatial mismatch between intersections and actual residences while also including those living within walking distance of the same bike share stations and similar BBSP outreach. Table 3-4 provides a summary of respondent locations relative to our resident survey BBSP outreach study area definitions. The relatively small share of respondents who overlapped with our resident outreach study areas limits our ability to draw comparisons between the two surveys, especially in Chicago.

Table 3-4 Correspondence with BBSP outreach study areas from resident survey

\begin{tabular}{|c|c|c|}
\hline \multirow[b]{2}{*}{ City } & \multicolumn{2}{|c|}{ Based on Geocoded Intersections ${ }^{1,2}$} \\
\hline & $\begin{array}{l}\text { Within Study } \\
\text { BBSP Outreach } \\
\text { Area }\end{array}$ & $\begin{array}{c}\text { Outside BBSP } \\
\text { Outreach Areas }\end{array}$ \\
\hline Philadelphia & 11 & 24 \\
\hline Chicago & 13 & 204 \\
\hline New York & 243 & 546 \\
\hline Total & 267 & 774 \\
\hline
\end{tabular}




\subsection{ABOUT THE RESPONDENTS}

\subsection{DEMOGRAPHIC AND BASIC BICYCLING INFORMATION ON RESPONDENTS}

Comparisons of the demographics of Brooklyn, Philadelphia and Chicago survey respondents to the overall city and bike share service area populations are shown in Table 4-1, Table 4-2 and Table 4-3, respectively. In Brooklyn, white, highly educated and higher-income respondents are considerably over-represented in the user survey relative to all people living near bike share in those cities. In Chicago, respondents were more likely to be white and college educated, but with incomes similar to the system coverage area. Philadelphia respondents were broadly representative of those living in the Indego service area in terms of race, education level and income. Across the three cities, the geographic area targeted for the survey were lower-income communities. However, the respondents were just as likely, or more likely, to be higher income than the city or bike share system as a whole. This would be consistent with past research indicating that bike share users tended to be higher income. 
Table 4-1 Brooklyn/New York City demographics

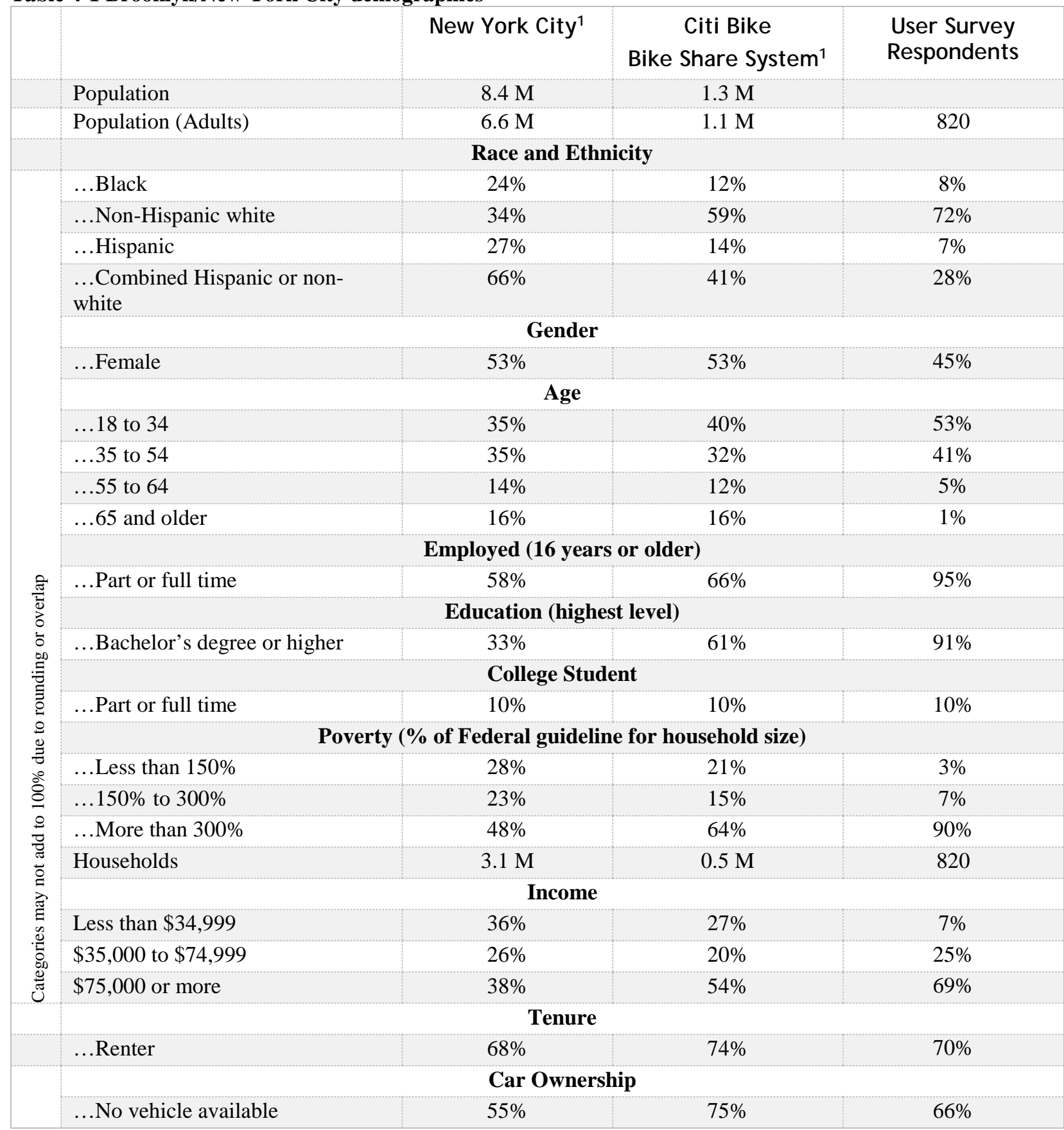

${ }^{1} 2015$ ACS 5-year Census. Census tracts with majority of area inside city boundary or with a bike share station, for system definition 
Table 4-2 Philadelphia demographics

\begin{tabular}{|c|c|c|c|c|}
\hline & & City $^{1}$ & $\begin{array}{l}\text { Indego Bike } \\
\text { Share System }\end{array}$ & $\begin{array}{l}\text { User Survey } \\
\text { Respondents }\end{array}$ \\
\hline & Population & $1.6 \mathrm{M}$ & $215 \mathrm{k}$ & \\
\hline & Population (Adults) & $1.3 \mathrm{M}$ & $205 \mathrm{k}$ & 38 \\
\hline & \multicolumn{4}{|c|}{ Race and Ethnicity } \\
\hline & ...Black & $41 \%$ & $22 \%$ & $27 \%$ \\
\hline & ...Non-Hispanic white & $40 \%$ & $57 \%$ & $47 \%$ \\
\hline & ...Hispanic & $11 \%$ & $7 \%$ & $9 \%$ \\
\hline & $\begin{array}{l}\text {...Combined Hispanic or non- } \\
\text { white }\end{array}$ & $60 \%$ & $43 \%$ & $53 \%$ \\
\hline & \multicolumn{4}{|c|}{ Gender } \\
\hline & ...Female & $54 \%$ & $51 \%$ & $62 \%$ \\
\hline & \multicolumn{4}{|c|}{ Age } \\
\hline \multirow{23}{*}{ 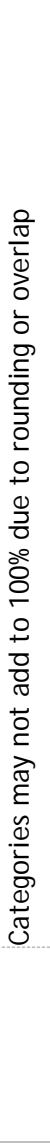 } & $\ldots 18$ to 34 & $38 \%$ & $54 \%$ & $50 \%$ \\
\hline & $\ldots 35$ to 54 & $32 \%$ & $24 \%$ & $37 \%$ \\
\hline & $\ldots 55$ to 64 & $14 \%$ & $10 \%$ & $8 \%$ \\
\hline & ...65 and older & $16 \%$ & $12 \%$ & $5 \%$ \\
\hline & \multicolumn{4}{|c|}{ Employed (16 years or older) } \\
\hline & ...Part or full time & $52 \%$ & $58 \%$ & $74 \%$ \\
\hline & \multicolumn{4}{|c|}{ Education } \\
\hline & ...Bachelor’s degree/higher & $23 \%$ & $50 \%$ & $49 \%$ \\
\hline & \multicolumn{4}{|c|}{ College Student } \\
\hline & ...Part or full time & $12 \%$ & $27 \%$ & $26 \%$ \\
\hline & \multicolumn{4}{|c|}{ Poverty (\% of Federal guideline for household size) } \\
\hline & ...Less than $150 \%$ & $34 \%$ & $30 \%$ & $33 \%$ \\
\hline & $\ldots 150 \%$ to $300 \%$ & $27 \%$ & $20 \%$ & $10 \%$ \\
\hline & ...More than $300 \%$ & $39 \%$ & $50 \%$ & $58 \%$ \\
\hline & Households & $0.6 \mathrm{M}$ & $92.7 \mathrm{k}$ & 38 \\
\hline & \multicolumn{4}{|c|}{ Income } \\
\hline & Less than $\$ 34,999$ & $47 \%$ & $35 \%$ & $42 \%$ \\
\hline & $\$ 35,000$ to $\$ 74,999$ & $30 \%$ & $26 \%$ & $25 \%$ \\
\hline & $\$ 75,000$ or more & $24 \%$ & $38 \%$ & $33 \%$ \\
\hline & \multicolumn{4}{|c|}{ Tenure } \\
\hline & ...Renter & $47 \%$ & $62 \%$ & $66 \%$ \\
\hline & \multicolumn{4}{|c|}{ Car Ownership } \\
\hline & ....No vehicle available & $32 \%$ & $42 \%$ & $54 \%$ \\
\hline
\end{tabular}

${ }^{1} 2015$ ACS 5-year Census. Census tracts with majority of area inside city boundary or with a bike share station, for system definition 
Table 4-3 Chicago demographics

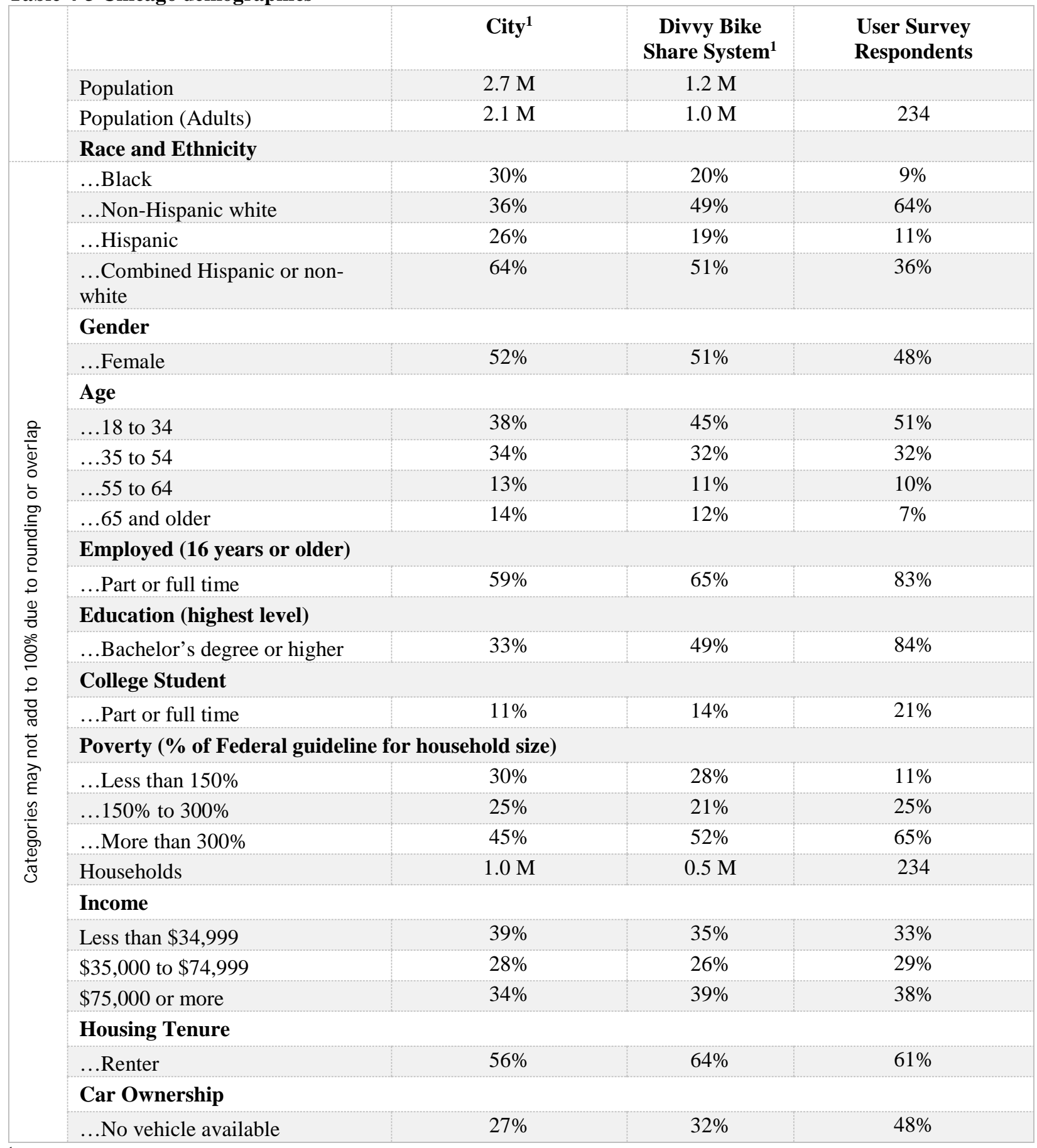

${ }^{1} 2015$ ACS 5-year Census. Census tracts with majority of area inside city boundary or with a bike share station, for system definition

\subsection{OTHER RESPONDENT CHARACTERISTICS}

To better understand the survey respondents, we asked questions about how they typically get around; about items that might affect their transportation options (such as if they have a driver's license, car, transit pass, bicycle, etc.); and about their options for getting information and 
making purchases (such as if they have a credit or debit card, smartphone or internet). We asked how long they had lived in their current home and neighborhood, and to provide a self-report on their overall health and level of physical activity. Responses to the transportation-related questions by survey area are shown in Table 4-4, while responses to other questions are shown in Table 4-5.

Respondents in Brooklyn were least likely to travel in a personal car (either for most or some trips), but were more likely than those in other cities to travel by taxi or car share for some trips. Brooklyn respondents were also more likely to take most trips by transit, while those in Philadelphia were least likely to do so. Respondents in Philadelphia were least likely to have a driver's license (74\% compared to $89-90 \%$ for other cities). They were also much less likely to have a car share membership or transit pass. Readers should keep in mind that the surveys were conducted in either winter (Chicago, Brooklyn) or early spring (Philadelphia). Respondents in Philadelphia were also least likely to have a credit card (74\%), debit card (79\%), or reliable internet access (87\%). 
Table 4-4 Transportation characteristics by city

\section{\begin{tabular}{|l|l|l|}
\hline Philadelphia & Chicago & Brooklyn \\
\hline
\end{tabular}}

In the past week, how did you get around? (\% Selected)

Drove a personal car

...most trips

...some trips

\begin{tabular}{|l|l|l|}
\hline $19 \%$ & $15 \%$ & $3 \%$ \\
\hline $31 \%$ & $38 \%$ & $24 \%$ \\
\hline
\end{tabular}

Got a ride from a friend or family member

...most trips

...some trips

$4 \%$

$46 \%$

$2 \%$

$0 \%$

Taxi/Uber/Lyft

...most trips

$2 \%$

$39 \%$

$18 \%$

...some trips

$51 \%$

$5 \%$

$2 \%$

Car share

...most trips

...some trips

$0 \%$

$6 \%$

$52 \%$

$65 \%$

\section{Public transit}

...most trips

...some trips

$21 \%$

$46 \%$

$43 \%$

$1 \%$

$0 \%$

$7 \%$

$11 \%$

\section{Walking}

...most trips

...some trips

$30 \%$

$66 \%$

$31 \%$

$39 \%$

\section{Bicycling - bike share}

...most trips

$16 \%$

$10 \%$

$19 \%$

...some trips

$33 \%$

$47 \%$

$60 \%$

\section{Bicycling - personal bike}

...most trips

...some trips

$21 \%$

$19 \%$

$8 \%$

$11 \%$

Do you currently have a...? (\% Yes)

Driver's license

$74 \%$

Car available for use

$46 \%$

$23 \%$

$29 \%$

Car share membership

Transit pass

Working bicycle

Min. number of responses ${ }^{1}$

Max. number of responses ${ }^{1}$

$8 \%$

$89 \%$

$90 \%$

$28 \%$

$44 \%$

39

56

$52 \%$

$34 \%$

$19 \%$

$33 \%$

Bold indicates category value significantly greater or less than expected ( $\mathrm{p}<0.05$, adj. stand. Chi-square residual). 
${ }^{1}$ varies by question due to missing

Table 4-5 Other social and demographic characteristics by city

\section{\begin{tabular}{l|l|l} 
Philadelphia & Chicago & Brooklyn
\end{tabular}}

Do you currently have a...? (\% Yes)

Smartphone

Credit card

\begin{tabular}{l|l|l}
$90 \%$ & $94 \%$ & $98 \%$
\end{tabular}

Debit card

Reliable internet access

$74 \%$

$84 \% \quad 94 \%$

$79 \%$

89\% $\quad 95 \%$

Subsidized housing or discount?

Yes

$10 \%$

$3 \%$

$2 \%$

How long have you lived at your current address?

$0-2$ years

2.1-5 years

6-10 years

11-20 years

$21+$ years

How long have you lived in your current neighborhood?

$0-2$ years

2.1-5 years

6-10 years

11-20 years

$21+$ years

\section{Health}

Excellent

Very good

Good

Fair

Poor

\section{Physically active}

Not at all

Not very

Somewhat

Very

Don't know/not sure

Min. number of responses ${ }^{1}$

Max. number of responses ${ }^{1}$

Bold indicates category value significa

${ }^{1}$ varies by question due to missing

\begin{tabular}{|l|l|l|}
\hline $58 \%$ & $50 \%$ & $47 \%$ \\
\cline { 1 - 1 } $14 \%$ & $21 \%$ & $27 \%$ \\
\hline $8 \%$ & $11 \%$ & $15 \%$ \\
\hdashline $11 \%$ & $10 \%$ & $8 \%$ \\
\hdashline $8 \%$ & $8 \%$ & $2 \%$ \\
\hline
\end{tabular}

\begin{tabular}{|c|c|c|}
\hline $37 \%$ & $37 \%$ & $34 \%$ \\
\hline $23 \%$ & $23 \%$ & $31 \%$ \\
\hline $14 \%$ & $13 \%$ & $19 \%$ \\
\hline $11 \%$ & $11 \%$ & $12 \%$ \\
\hline $14 \%$ & $15 \%$ & $3 \%$ \\
\hline
\end{tabular}

\begin{tabular}{|l|l|l|}
\hline $26 \%$ & $22 \%$ & $26 \%$ \\
\hline $44 \%$ & $48 \%$ & $43 \%$ \\
\hline $23 \%$ & $25 \%$ & $26 \%$ \\
\hline $8 \%$ & $5 \%$ & $3 \%$ \\
\hline $0 \%$ & $0 \%$ & $0 \%$ \\
\hline
\end{tabular}




\subsection{GROUPS FOR ANALYSIS}

A major goal of the survey was to understand how the programs focused on engaging lowerincome individuals and people of color were working, and what the experiences and perceptions of these individuals were in regard to bicycling and bike share. To do this, we sought to break the respondents into three groups:

- "BBSP target users" or lower-income and/or respondents of color (equity target users) who had taken advantage of some element of the types of equity-related outreach that BBSP promoted (either through receiving an equity-targeted discount rate, using the cash payment or participating in an outreach event like an organized ride);

- "Non-BBSP target users" or other lower-income and/or respondents of color (equity target users) who did not specifically partake in one of these outreach efforts; and,

- "Higher-income, white users" who are not the target of the BBSP programs and are more representative of the typical bike share user, according to prior research.

For the purposes of this breakdown, lower income was defined as earning less than $300 \%$ of the federal household poverty threshold. Among all survey respondents, we had a relatively low number of people in the first group (those who were lower income and/or people of color and participated in some aspect of the equity outreach).

While we had originally sought to analyze the lower-income members and the respondents of color in this group separately, we ended up combining them into this one group due to the low overall numbers. Even when combined, the low number of BBSP target users (70) at times limited our ability to identify significant differences with other groups.

A breakdown of the categorization of respondents by city is shown in Table 4-6. Overall, $40 \%$ of respondents could not be categorized into one of these groups; $73 \%$ of those were people who did not complete the survey (and, in most cases, did not provide any demographic information), while the remainder either did not provide enough demographic or participation information to be categorized. As mentioned earlier, the large number of responses from higher-income, white users is likely due to their overrepresentation about bike share users.

Chicago respondents made up nearly two-thirds of the BBSP target users, where the large number of D4E members provided a significant pool of potential respondents. Respondents from Brooklyn made up the majority of non-BBSP target users (85\%) and higher-income, white users (85\%), which is not surprising given the much higher number of respondents there overall. 
Table 4-6 Analysis group categorization by city

\begin{tabular}{|c|c|c|c|c|c|}
\hline & Philadelphia & Chicago & Brooklyn & $\begin{array}{c}\text { All } \\
\text { cities }\end{array}$ & $\begin{array}{c}\text { Number of } \\
\text { responses }\end{array}$ \\
\hline \multicolumn{6}{|c|}{ Among all respondents } \\
\hline BBSP target users & $20 \%$ & $17 \%$ & $1 \%$ & $5 \%$ & 70 \\
\hline Non-BBSP target users & $8 \%$ & $11 \%$ & $16 \%$ & $15 \%$ & 224 \\
\hline Higher-income, white users & $16 \%$ & $30 \%$ & $44 \%$ & $40 \%$ & 591 \\
\hline Not able to categorize & $56 \%$ & $42 \%$ & $39 \%$ & $40 \%$ & 588 \\
\hline Total & $100 \%$ & $100 \%$ & $100 \%$ & $100 \%$ & 1,473 \\
\hline Number of responses & 50 & 269 & 1,154 & 1,473 & \\
\hline \multicolumn{6}{|c|}{ Among those categorized - percent within city } \\
\hline BBSP target users & $45 \%$ & $29 \%$ & $2 \%$ & $8 \%$ & 70 \\
\hline Non-BBSP target users & $18 \%$ & $19 \%$ & $27 \%$ & $25 \%$ & 224 \\
\hline Higher-income, white users & $36 \%$ & $52 \%$ & $71 \%$ & $67 \%$ & 591 \\
\hline Total & $100 \%$ & $100 \%$ & $100 \%$ & $100 \%$ & 885 \\
\hline Number of responses & 22 & 155 & 708 & 885 & \\
\hline \multicolumn{6}{|c|}{ Among those categorized - percent within group } \\
\hline BBSP target users & $14 \%$ & $64 \%$ & $21 \%$ & $100 \%$ & 70 \\
\hline Non-BBSP target users & $2 \%$ & $13 \%$ & $85 \%$ & $100 \%$ & 224 \\
\hline Higher-income, white users & $1 \%$ & $14 \%$ & $85 \%$ & $100 \%$ & 591 \\
\hline Total & $2 \%$ & $18 \%$ & $80 \%$ & $100 \%$ & 885 \\
\hline Number of responses & 22 & 155 & 708 & 885 & \\
\hline
\end{tabular}

Percentages may not add up to $100 \%$ due to rounding.

Demographic and travel information about the respondents broken down by these analysis groups is shown in Table 4-7, Table 4-8 and Table 4-9. BBSP target users were more likely to be older and less likely to have a college degree. In addition, fewer of the respondents in this group indicated that they were in "excellent" health. These findings may indicate the effectiveness of the BBSP programs in reaching a wider demographic. On the other hand, a smaller share of this group were women. Among lower-income women of color, just 26\% reported receiving equityrelated discounts or outreach versus a significantly higher $59 \%$ share of lower-income men of color. BBSP target users were significantly less likely to have a smartphone (at 89\%), a credit card (at 70\%), debit card (81\%), or reliable internet access (at 89\%). BBSP target users were the least likely to have a driver's license (at $80 \%$ ) or a car share membership (at 11\%); however, they were still most likely to make most trips by personal car (at 14\%). They were also more likely than any other group to use bike share for most trips (21\%), though the difference was not significant. Higher-income whites were considerably more likely to have access to a personal bike (63\%) than were BBSP target (39\%) or non-BBSP target (49\%) respondents. 
Table 4-7 Individual characteristics by analysis group

\begin{tabular}{|c|c|c|c|}
$\begin{array}{c}\text { BBSP } \\
\text { target users }\end{array}$ & $\begin{array}{c}\text { Non-BBSP } \\
\text { target users }\end{array}$ & $\begin{array}{c}\text { Higher-income, } \\
\text { white users }\end{array}$ & Total \\
\end{tabular}

\section{Age}

18-34

35-54

55-64

65+

$48 \%$

$32 \%$

$10 \%$

$10 \%$

$\begin{array}{r}\mathbf{6 4 \%} \\ \mathbf{3 2 \%} \\ \hline 4 \% \\ \hline 1 \%\end{array}$

\begin{tabular}{|c|c|}
\hline $\mathbf{4 9} \%$ & $53 \%$ \\
\hline $\mathbf{4 5 \%}$ & $40 \%$ \\
\hline $6 \%$ & $6 \%$ \\
\hline $1 \%$ & $1 \%$ \\
\hline
\end{tabular}

\section{Gender}

Female

$34 \%$

$54 \%$

$42 \%$

$44 \%$

\section{Race/Ethnicity}

\begin{tabular}{l|l} 
Hispanic & \\
Black &
\end{tabular}

White

$13 \%$

$20 \%$

$20 \%$

$23 \%$

$47 \%$

$17 \%$

Asian

American Indian/Alaska Native

$11 \%$

Multiple races

$3 \%$

$6 \%$

$28 \%$

$0 \%$

\section{Health}

\begin{tabular}{|l|r}
\hline Excellent & 170 \\
Very good & 390 \\
Good & $36 \%$
\end{tabular}

$17 \%$

\begin{tabular}{|c|c|c|}
\hline $22 \%$ & $\mathbf{2 9 \%}$ & $26 \%$ \\
\hline $45 \%$ & $43 \%$ & $43 \%$ \\
\hline $29 \%$ & $24 \%$ & $26 \%$ \\
\hline $4 \%$ & $4 \%$ & $4 \%$ \\
\hline $0 \%$ & $0 \%$ & $0 \%$ \\
\hline
\end{tabular}

Physically active

Not active at all

Not very active

Somewhat active

Very active

$39 \%$

$36 \%$

$7 \%$

$1 \%$

$10 \%$

0\%

\begin{tabular}{l|l}
$\mathbf{0 \%}$ & $7 \%$
\end{tabular}

Don't know/not sure

\begin{tabular}{l|l}
$1 \%$ & \\
$10 \%$ & \\
$50 \%$ & \\
$39 \%$ & \\
$0 \%$ &
\end{tabular}

$0 \%$

$\mathbf{1 0 0} \% \quad 75 \%$

\begin{tabular}{l|l}
$0 \%$ & $8 \%$
\end{tabular}

$0 \% \quad 0 \%$

\begin{tabular}{l|l}
$0 \%$ & $3 \%$
\end{tabular}

\section{Employment and Education}

\begin{tabular}{|c|c|c|c|c|}
\hline 1 job & $54 \%$ & $74 \%$ & $81 \%$ & $77 \%$ \\
\hline 2 or more jobs & $16 \%$ & $20 \%$ & $15 \%$ & $16 \%$ \\
\hline Not employed & $30 \%$ & $6 \%$ & $5 \%$ & $7 \%$ \\
\hline 35 hours or more & $78 \%$ & $83 \%$ & $92 \%$ & $89 \%$ \\
\hline Student & $15 \%$ & $15 \%$ & $9 \%$ & $11 \%$ \\
\hline Bachelor degree or more & $64 \%$ & $86 \%$ & $94 \%$ & $90 \%$ \\
\hline Responses received & $49-70$ & 213-224 & $567-591$ & 829-885 \\
\hline
\end{tabular}

Bold indicates category value significantly greater or less than expected ( $<<0.05$, adj. stand. Chi-square residual). $\mathrm{N}$ varies by question due to non-responses. 
Table 4-8 Household characteristics by analysis group

\begin{tabular}{|c|c|c|c|c|}
\hline & $\begin{array}{l}\text { BBSP target } \\
\text { users }\end{array}$ & $\begin{array}{l}\text { Non-BBSP } \\
\text { target users }\end{array}$ & $\begin{array}{l}\text { Higher-income, } \\
\text { white users }\end{array}$ & Total \\
\hline Renter & $69 \%$ & $76 \%$ & $65 \%$ & $68 \%$ \\
\hline Rental subsidy & $12 \%$ & $3 \%$ & $0 \%$ & $2 \%$ \\
\hline \multicolumn{5}{|l|}{ Years at current address } \\
\hline 0 to 2 years & $46 \%$ & $46 \%$ & $50 \%$ & $49 \%$ \\
\hline 2.1 to 5 years & $20 \%$ & $28 \%$ & $25 \%$ & $25 \%$ \\
\hline 5.1 to 10 years & $17 \%$ & $12 \%$ & $14 \%$ & $14 \%$ \\
\hline 11 to 20 years & $6 \%$ & $9 \%$ & $9 \%$ & $9 \%$ \\
\hline 21 years or more & $11 \%$ & $5 \%$ & $2 \%$ & $3 \%$ \\
\hline \multicolumn{5}{|l|}{ Years in neighborhood } \\
\hline 0 to 2 years & $35 \%$ & $35 \%$ & $36 \%$ & $35 \%$ \\
\hline 2.1 to 5 years & $21 \%$ & $32 \%$ & $30 \%$ & $29 \%$ \\
\hline 5.1 to 10 years & $20 \%$ & $13 \%$ & $19 \%$ & $18 \%$ \\
\hline 11 to 20 years & $8 \%$ & $13 \%$ & $12 \%$ & $12 \%$ \\
\hline 21 years or more & $17 \%$ & $8 \%$ & $4 \%$ & $6 \%$ \\
\hline \multicolumn{5}{|l|}{ Annual Household Income } \\
\hline$<\$ 35,000$ & $73 \%$ & $23 \%$ & 0\% & $12 \%$ \\
\hline$\$ 35,000$ to $\$ 74,999$ & $17 \%$ & $26 \%$ & $24 \%$ & $24 \%$ \\
\hline$\$ 75,000+$ & $10 \%$ & $50 \%$ & $76 \%$ & $64 \%$ \\
\hline \multicolumn{5}{|l|}{ Income statement } \\
\hline I/we can't make ends meet & $19 \%$ & $5 \%$ & $1 \%$ & $3 \%$ \\
\hline I/we have just enough, no more & $42 \%$ & $24 \%$ & $19 \%$ & $22 \%$ \\
\hline I/we have enough, with a little extra sometimes & $29 \%$ & $52 \%$ & $49 \%$ & $48 \%$ \\
\hline I/we always have money left over & $10 \%$ & $20 \%$ & $32 \%$ & $27 \%$ \\
\hline \multicolumn{5}{|l|}{ Do you currently have a ... } \\
\hline Smartphone & $89 \%$ & $97 \%$ & $\mathbf{9 8 \%}$ & $97 \%$ \\
\hline Credit card & $70 \%$ & $93 \%$ & $96 \%$ & $93 \%$ \\
\hline Debit card & $81 \%$ & $96 \%$ & $95 \%$ & $94 \%$ \\
\hline Reliable internet access & $89 \%$ & $95 \%$ & $99 \%$ & $97 \%$ \\
\hline Responses received & $58-70$ & $193-224$ & $455-591$ & $829-885$ \\
\hline
\end{tabular}

Bold indicates category value significantly greater or less than expected ( $\mathrm{p}<0.05$, adj. stand. Chi-square residual). $\mathrm{N}$ varies by question due to non-responses. 
Table 4-9 Travel characteristics by analysis group

\begin{tabular}{|c|c|c|c|c|}
\hline & $\begin{array}{c}\text { BBSP target } \\
\text { users }\end{array}$ & $\begin{array}{c}\text { Non-BBSP target } \\
\text { users }\end{array}$ & $\begin{array}{l}\text { Higher-income, } \\
\text { white users }\end{array}$ & Total \\
\hline \multicolumn{5}{|c|}{ Do you currently have a... } \\
\hline Driver's license & $80 \%$ & $85 \%$ & $94 \%$ & $91 \%$ \\
\hline Transit pass & $74 \%$ & $80 \%$ & $83 \%$ & $81 \%$ \\
\hline Working bicycle & $39 \%$ & $49 \%$ & $63 \%$ & $57 \%$ \\
\hline Car available for use & $30 \%$ & $28 \%$ & $44 \%$ & $39 \%$ \\
\hline Car share membership & $11 \%$ & $31 \%$ & $32 \%$ & $30 \%$ \\
\hline \multicolumn{5}{|l|}{ Trips in past week } \\
\hline \multicolumn{5}{|l|}{ Drove a personal car } \\
\hline Most trips & $14 \%$ & $3 \%$ & $4 \%$ & $4 \%$ \\
\hline Some trips & $21 \%$ & $22 \%$ & $32 \%$ & $28 \%$ \\
\hline \multicolumn{5}{|c|}{ Got a ride from a friend or family member } \\
\hline Most trips & $2 \%$ & $0 \%$ & $0 \%$ & $0 \%$ \\
\hline Some trips & $40 \%$ & $26 \%$ & $18 \%$ & $22 \%$ \\
\hline \multicolumn{5}{|l|}{ Taxi / Uber / Lyft } \\
\hline Most trips & $2 \%$ & $2 \%$ & $2 \%$ & $2 \%$ \\
\hline Some trips & $48 \%$ & $58 \%$ & $63 \%$ & $60 \%$ \\
\hline \multicolumn{5}{|c|}{ Car Share (Zipcar, Enterprise CarShare, etc.) } \\
\hline Most trips & $0 \%$ & $0 \%$ & $0 \%$ & $0 \%$ \\
\hline Some trips & 0\% & $8 \%$ & $11 \%$ & $9 \%$ \\
\hline \multicolumn{5}{|c|}{ Public transit (bus, rail, etc.) } \\
\hline Most trips & $49 \%$ & $57 \%$ & $55 \%$ & $55 \%$ \\
\hline Some trips & $35 \%$ & $38 \%$ & $41 \%$ & $40 \%$ \\
\hline \multicolumn{5}{|l|}{ Walking } \\
\hline Most trips & $30 \%$ & $40 \%$ & $40 \%$ & $39 \%$ \\
\hline Some trips & $66 \%$ & $59 \%$ & $60 \%$ & $60 \%$ \\
\hline \multicolumn{5}{|l|}{ Bicycling - bike share } \\
\hline Most trips & $21 \%$ & $19 \%$ & $16 \%$ & $17 \%$ \\
\hline Some trips & $50 \%$ & $66 \%$ & $63 \%$ & $63 \%$ \\
\hline \multicolumn{5}{|c|}{ Bicycling - personal bike } \\
\hline Most trips & $7 \%$ & $10 \%$ & $14 \%$ & $12 \%$ \\
\hline Some trips & $26 \%$ & $24 \%$ & $29 \%$ & $27 \%$ \\
\hline Responses received & $63-69$ & $202-220$ & $508-582$ & $773-869$ \\
\hline
\end{tabular}

Bold indicates category value significantly greater or less than expected ( $<<0.05$, adj. stand. Chi-square residual). $\mathrm{N}$ varies by question due to non-responses. 


\subsection{ANALYSIS}

For each group difference, we calculated standardized adjusted chi-square residuals in SPSS. By convention, residuals with absolute values of two or greater indicate an interesting and likely statistically significant $(\mathrm{p}<=0.05)$ difference for a group (Sharpe, 2015). Notes on statistical significance refer to a $5 \%$ significance level, unless otherwise noted. 


\subsection{BIKE SHARE MEMBERSHIP AND EXPERIENCES}

\subsection{MEMBERSHIPS}

Membership details for respondents are shown in Table 5-1. BBSP target users were significantly more likely to have let their bike share membership lapse (19\% vs. $9 \%$ of all respondents). In our sample, this difference was driven primarily by a higher rate of non-renewal among BBSP target respondents in Chicago (22\%), along with generally high retention rates among all groups in Brooklyn (where the majority of non-BBSP target and higher-income white respondents lived). In Chicago, income-based passes increase in cost from \$5 to \$50 per year after the first year. Of current members, higher-income, white users were more likely to pay for the memberships annually rather than monthly. BBSP target users were least likely to have paid for a short-term use of bike share, such as per ride, day or three-day period.

Somewhat by definition, most BBSP target users had a discounted membership, although a few did not; they likely had participated in outreach events or other activities. Still, a considerable number of the non-BBSP target users and higher-income, white users were also receiving some type of discount - 43\% and 32\%, respectively - generally through their employer, school or other non-equity-focused promotion or discount. In terms of payment methods, nearly two-thirds of the BBSP target users had made cash payments for their membership. For some of the discount programs, cash was the only payment option. 
Table 5-1 Membership information

\begin{tabular}{|c|c|c|c|c|}
\hline & $\begin{array}{l}\text { BBSP target } \\
\text { users }\end{array}$ & $\begin{array}{c}\text { Non-BBSP target } \\
\text { users }\end{array}$ & $\begin{array}{l}\text { Higher-income, } \\
\text { white users }\end{array}$ & All \\
\hline \multicolumn{5}{|l|}{ Are you a [BssName] member? } \\
\hline Yes, current member & $80 \%$ & $97 \%$ & $90 \%$ & $91 \%$ \\
\hline Was a member in the past & $19 \%$ & $3 \%$ & $10 \%$ & $9 \%$ \\
\hline No, never have been a member & $1 \%$ & $0 \%$ & $0 \%$ & $0 \%$ \\
\hline $\mathrm{n}$ & 70 & 224 & 591 & 885 \\
\hline \multicolumn{5}{|c|}{ Current method of payment for [BssName] membership } \\
\hline Monthly & $14 \%$ & $11 \%$ & $4 \%$ & $7 \%$ \\
\hline Annually & $87 \%$ & $89 \%$ & $94 \%$ & $92 \%$ \\
\hline Unknown & $0 \%$ & $1 \%$ & $1 \%$ & $1 \%$ \\
\hline $\mathrm{n}$ & 52 & 210 & 521 & 783 \\
\hline \multicolumn{5}{|l|}{ Have you ever used bike share by ... } \\
\hline Paid up front for annual membership & $79 \%$ & $88 \%$ & $94 \%$ & $91 \%$ \\
\hline Paid monthly & $20 \%$ & $13 \%$ & $6 \%$ & $9 \%$ \\
\hline $\begin{array}{l}\text { Paid for short term use (per ride, day or three- } \\
\text { day) }\end{array}$ & $16 \%$ & $33 \%$ & $33 \%$ & $32 \%$ \\
\hline Used a friend's bike/membership & $7 \%$ & $13 \%$ & $10 \%$ & $11 \%$ \\
\hline $\mathrm{n}$ & 70 & 224 & 591 & 885 \\
\hline \multicolumn{5}{|l|}{ Discounted memberships } \\
\hline Have a discounted [BssName] membership & $95 \%$ & $43 \%$ & $32 \%$ & $39 \%$ \\
\hline \multicolumn{5}{|l|}{ Types of discount } \\
\hline $\begin{array}{l}\text { Targeted discount program } \\
\text { (e.g., NYCHA or Credit Union in New York; } \\
\text { Divvy for Everyone in Chicago; or, PA Access } \\
\text { in Philadelphia) }\end{array}$ & $95 \%$ & $0 \%$ & $3 \%$ & $9 \%$ \\
\hline $\begin{array}{l}\text { Other discount } \\
\text { (e.g., through employer, school, promotion, } \\
\text { etc.) }\end{array}$ & $5 \%$ & $41 \%$ & $27 \%$ & $30 \%$ \\
\hline $\mathrm{n}$ & 56 & 224 & 542 & 822 \\
\hline \multicolumn{5}{|l|}{ Cash payment } \\
\hline Have paid with cash & $64 \%$ & $0 \%$ & $0.5 \%$ & \\
\hline $\mathrm{n}$ & 56 & 218 & 805 & \\
\hline
\end{tabular}

Bold indicates category value significantly greater or less than expected $(\mathrm{p}<0.05$, adj. stand. Chi-square residual). $\mathrm{N}$ varies by question due to non-responses. [BssName] is used as a place holder for the specific name of the city bike share program used in the surveys.

Cash payment options were available in Chicago and Philadelphia. For respondents in those cities who indicated that they had paid with cash, we asked them about the difficulty of getting to the payment location, completing the sign-up and payment process, and about the overall process of getting and using a cash membership, as shown in Table 5-2. The cash payment option in 
Chicago was limited to D4E members signing up at one of five LISC offices in the city. This limitation may be one of the reasons why members in Chicago were much more likely to say that getting to the location to purchase the cash membership was difficult. In Philadelphia, although we only had 11 respondents who had made cash payments, none indicated that it was difficult in terms of the three items presented.

Table 5-2 Cash membership process

\begin{tabular}{|l|c|c|c|c|c|}
\hline $\begin{array}{c}\text { How easy were the following ways of } \\
\text { getting and using a discounted } \\
\text { membership? }\end{array}$ & City & $\begin{array}{c}\text { "Very } \\
\text { difficult" } \\
\text { or } \\
\text { "Difficult" }\end{array}$ & $\begin{array}{c}\text { Neither easy } \\
\text { nor difficult }\end{array}$ & $\begin{array}{c}\text { "Easy" or } \\
\text { "Very } \\
\text { easy" }\end{array}$ & n \\
\hline $\begin{array}{l}\text { Getting to locations to purchase a cash } \\
\text { membership }\end{array}$ & Chicago & $41 \%$ & $26 \%$ & $32 \%$ & 34 \\
\hline $\begin{array}{l}\text { Completing sign-up and making } \\
\text { payment }\end{array}$ & Philadelphia & $0 \%$ & $18 \%$ & $82 \%$ & 11 \\
\hline $\begin{array}{l}\text { Overall process of getting and using a } \\
\text { cash membership }\end{array}$ & Chicago & $15 \%$ & $24 \%$ & $62 \%$ & 34 \\
\hline & Chiladelphia & $0 \%$ & $27 \%$ & $73 \%$ & 11 \\
\hline
\end{tabular}

\subsubsection{Friends and family who use bike share}

Although only $43 \%$ of respondents told us that they had friends or family who had used bike share prior to the respondent becoming a member, a much higher share of respondents indicated that they currently had one or more friends, family or close acquaintances with bike share memberships. In fact, as shown in Table 5-3, only 17\% of all respondents said they had zero friends, family members or acquaintances with memberships, while $18 \%$ had one, 39\% had two or three, and $26 \%$ had four or more. Among respondents, BBSP target users were more likely to have zero such connections, with 34\% indicating as much, compared to only $13 \%$ of higherincome, white users. Correspondingly, BBSP target users were also less likely to have four or more such connections, with only $14 \%$ indicating as much, compared to $30 \%$ of higher-income, white users.

Table 5-3 How many of your family/friends/close acquaintances have [BssName] memberships?

\begin{tabular}{|l|c|c|c|c|}
\hline & BBSP target users & $\begin{array}{c}\text { Non-BBSP target } \\
\text { users }\end{array}$ & $\begin{array}{c}\text { Higher-income, } \\
\text { white users }\end{array}$ & All \\
\hline 0 / zero & $\mathbf{3 4 \%}$ & $22 \%$ & $\mathbf{1 3 \%}$ & $17 \%$ \\
\hline 1 & $21 \%$ & $21 \%$ & $17 \%$ & $18 \%$ \\
\hline $2-3$ & $30 \%$ & $38 \%$ & $40 \%$ & $39 \%$ \\
\hline 4 or more & $\mathbf{1 4 \%}$ & $\mathbf{1 9 \%}$ & $\mathbf{3 0 \%}$ & $26 \%$ \\
\hline $\begin{array}{l}\text { Responses } \\
\text { received }\end{array}$ & 70 & 223 & 589 & 882 \\
\hline
\end{tabular}

Bold indicates category value significantly greater or less than expected ( $\mathrm{p}<0.05$, adj. stand. Chi-square residual). [BssName] is used as a place holder for the specific name of the city bike share program used in the surveys. 


\subsubsection{Reason for becoming a bike share member (or reasons for bike share membership)}

We asked respondents to "please describe why you chose to try bike share or become a member," and provided an open space for people to type in their response. We received written comments from 740 people, and coded them into thematic categories. Some responses were coded into multiple categories if they touched on multiple themes.

The top cited reason for becoming a member had to do with the sense that bike share and bicycling was a convenient way to get around the city. A quarter of respondents hit on this theme, with many indicating that it was more reliable than other methods. After that, a group of four other themes emerged, each with $15-18 \%$ of respondents discussing them in their responses: the physical and mental benefits of bicycling, the benefit of being able to bike without needing to deal with owning a bike, the relative affordability of a bike share membership (usually in comparison to transit or taxi fares, though occasionally in relation to single-ride bike share use), and that bike share was faster or better than other transportation modes.

Among the notable differences between the analysis groups, the top two themes emerging from the BBSP target users were quite different from other users. In particular, 30\% of BBSP target users touched on the importance of the discount in deciding to join, while it's not surprising that far fewer of the other respondents (who, partially by definition, were less likely to have received discounted membership). The second most common response in this group related to the cost savings or value of the membership (25\% touched on this theme), which is likely partially related to the lower membership cost for most in this group. BBSP target users were also somewhat less likely to mention the ease or convenience of bike share (17\% compared to $25-28 \%$ of other users, though not a significant difference); that it was a good way to get around ( $0 \%$ compared to $5-8 \%$ of other users); using bike share to connect to public transit ( $2 \%$ compared to $9-11 \%$ of others); and a desire to support the bike share system (0\% compared to 7-8\%). 
Table 5-4 Open-ended responses - Why became a bike share member

\begin{tabular}{|c|c|c|c|c|}
\hline Coded Response Category & $\begin{array}{l}\text { BBSP target } \\
\text { users }\end{array}$ & $\begin{array}{l}\text { Non-BBSP } \\
\text { target users }\end{array}$ & $\begin{array}{l}\text { Higher-income, } \\
\text { white users }\end{array}$ & Total \\
\hline Convenience/ ease & $17 \%$ & $28 \%$ & $25 \%$ & $25 \%$ \\
\hline Physical and mental benefits & $18 \%$ & $19 \%$ & $18 \%$ & $18 \%$ \\
\hline Benefits of not using/ owning own bike & $17 \%$ & $14 \%$ & $19 \%$ & $17 \%$ \\
\hline Cost savings or value & $25 \%$ & $15 \%$ & $15 \%$ & $15 \%$ \\
\hline $\begin{array}{l}\text { Faster/ better than other transportation } \\
\text { methods }\end{array}$ & $18 \%$ & $15 \%$ & $14 \%$ & $15 \%$ \\
\hline Enjoy biking/ fun way to get around & $8 \%$ & $13 \%$ & $11 \%$ & $11 \%$ \\
\hline Connections between public transit & $2 \%$ & $9 \%$ & $11 \%$ & $9 \%$ \\
\hline Discounted membership & $30 \%$ & $8 \%$ & $7 \%$ & $9 \%$ \\
\hline Support the service & $0 \%$ & $7 \%$ & $8 \%$ & $7 \%$ \\
\hline Good way to get around & $0 \%$ & $5 \%$ & $8 \%$ & $6 \%$ \\
\hline $\begin{array}{l}\text { Access to areas poorly served by public } \\
\text { transit }\end{array}$ & $2 \%$ & $7 \%$ & $6 \%$ & $6 \%$ \\
\hline Station nearby & $2 \%$ & $6 \%$ & $5 \%$ & $5 \%$ \\
\hline Reduce emissions and congestion & $2 \%$ & $3 \%$ & $5 \%$ & $4 \%$ \\
\hline No bike at the time & $2 \%$ & $2 \%$ & $3 \%$ & $3 \%$ \\
\hline Alternative to other modes & $3 \%$ & $3 \%$ & $3 \%$ & $3 \%$ \\
\hline Used other bike share & $2 \%$ & $3 \%$ & $2 \%$ & $2 \%$ \\
\hline Social/ peers & $2 \%$ & $2 \%$ & $1 \%$ & $1 \%$ \\
\hline Responses received & 60 & 191 & 489 & 740 \\
\hline
\end{tabular}

Bold indicates category value significantly greater or less than expected ( $\mathrm{p}<0.05$, adj. stand. Chi-square residual).

A sampling of some of the responses given by BBSP target members are included below:

- I often go to the Metra train. It's a 30 minute walk or $\$ 2.25$ bus ride but with Divvy it's a 10 minute bike ride and since I've already paid the annual fee and 30 minute or less rides are included, it seems "free".

- I became a member because it seemed like something that would help get me more active, be able to ride bikes (which I enjoy doing) in a casual way, and it was available to me even with my low income, which made me feel like it was something worth trying.

- Exercise, cut down subway-bus fair, "not-my-bike" attitude, no worry of stealing/robbing, no parking/moving ticket.

- Getting back and forth to work and not using my personal bike for security reasons. I don't like locking my bike up on the street for long periods of time.

- Because of the low income program - I liked the idea of being able to use a bike at will and not necessarily be tied to a bike I owned-I can bike somewhere and take the bus back, for example.

- I like the exercise and I only use public transportation and using the divvy can really make my errand running much faster.

- Divvy is convenient for me, however I do not feel the streets are safe enough to bike comfortably. I decided to get a membership several months ago because I qualified for the Divvy for Everyone program, which was unfortunately only a one-time offer. 
- It's an experiment to see if it adds value to my life. Right now proving limited because it's not near my job in [the Bronx], nor in Harlem, so no link for me to home.

- I was in a bad bicycle accident in 2008. Last year I finally thought I might be able to start riding again but didn't want to invest in a new bike if I couldn't do it. A team member told me about Divvy "Free for All", I paid $\$ 5.00$ and got a key. It still took me about a month to get the courage up to actually get on a Divvy, but after about 10 minutes (after I stopped hyperventilating and feeling I would be sick) I was hooked. I've been riding ever since.

- Because stations were added near my house and near my work and because of the divvy for everyone discount program

\subsection{EXPOSURE TO INFORMATION ABOUT BIKE SHARE}

The survey asked respondents several sets of questions about experiences they had prior to becoming a bike share member. For respondents who were not bike share members (but had participated in outreach programs such as organized rides), the questions asked about if they had ever had the experiences.

\subsubsection{Sources of bike share information}

We asked respondents where they had gotten information about bike share before they became members. This is important because we found that many of the residents surveyed lacked important information about bike share. Knowing how these user groups obtained information could be useful in developing better outreach programs. People could select all that apply (or none) from among the list of options shown in Table 5-5. If they selected an option, they were asked to rate the importance of that information source in their decision to become a member (on a scale from not important, somewhat important, important or very important, along with the option of "not sure").

Among all users, the most cited sources of information were from the internet (68\% selected), from friends or family (46\%) and at the bike share kiosk (37\%). No other sources of information were cited by more than $13 \%$ of respondents. Of the top three sources of information, the internet and friends/family were listed as very important in terms of their decision to become a bike share member by over half of the people who selected that source. Comparatively, only a quarter of those who selected that they got information about bike share from the kiosk said that was a very important source of information in terms of their decision to join. Several other sources of information, while less commonly cited, were listed as very important by quite a few of those who did get information from that source. For example, although only $9 \%$ got information about bike share from their place of work or school, $40 \%$ of those who did said this source was important in deciding to join. Only $1 \%$ cited talking to one of the local BBSP outreach partners in their city; however, $69 \%$ of those who did said that it was very important in their decision to join.

BBSP target users were less likely to get information about bike share from their friends or family (33\% compared to $46 \%$ of all users), but were more likely to have gotten information 
about bike share from certain media sources (newspapers, ads on buses, bus shelters or billboards, and on television) and from some other personal sources of information such as talking to someone at an event, information at work or schools, talking to one of the community outreach partners, and at a community or faith-based organization.

Table 5-5 Sources of bike share information, and stated importance in decision to become a bike share member

\begin{tabular}{|c|c|c|c|c|c|c|c|c|}
\hline & \multicolumn{2}{|c|}{ BBSP target users } & \multicolumn{2}{|c|}{$\begin{array}{c}\text { Non-BBSP target } \\
\text { users }\end{array}$} & \multicolumn{2}{|c|}{$\begin{array}{l}\text { Higher-income, } \\
\text { white users }\end{array}$} & \multicolumn{2}{|r|}{ All } \\
\hline & Selected & $\begin{array}{l}\text { Of those, } \\
\% \text { rating } \\
\text { "Very } \\
\text { Important" }\end{array}$ & Selected & $\begin{array}{l}\text { Of those, } \\
\text { \% rating } \\
\text { "Very } \\
\text { Important" }\end{array}$ & Selected & $\begin{array}{l}\text { Of those, } \\
\text { \% rating } \\
\text { "Very } \\
\text { Important" }\end{array}$ & Selected & $\begin{array}{l}\text { Of those, } \\
\text { \% rating } \\
\text { "Very } \\
\text { Important" }\end{array}$ \\
\hline On the internet & $63 \%$ & $68 \%$ & $62 \%$ & $58 \%$ & $70 \%$ & $55 \%$ & $68 \%$ & $57 \%$ \\
\hline Friends or family & $33 \%$ & $48 \%$ & $44 \%$ & $52 \%$ & $49 \%$ & $52 \%$ & $46 \%$ & $52 \%$ \\
\hline $\begin{array}{l}\text { At a bike share } \\
\text { station/kiosk }\end{array}$ & $44 \%$ & $23 \%$ & $42 \%$ & $21 \%$ & $34 \%$ & $26 \%$ & $37 \%$ & $24 \%$ \\
\hline Newspaper & $24 \%$ & $41 \%$ & $8 \%$ & $16 \%$ & $14 \%$ & $15 \%$ & $13 \%$ & $19 \%$ \\
\hline $\begin{array}{l}\text { Talked to someone } \\
\text { at an event }\end{array}$ & $21 \%$ & $33 \%$ & $10 \%$ & $27 \%$ & $9 \%$ & $26 \%$ & $10 \%$ & $28 \%$ \\
\hline $\begin{array}{l}\text { Information at } \\
\text { work or school }\end{array}$ & $20 \%$ & $50 \%$ & $9 \%$ & $38 \%$ & $7 \%$ & $40 \%$ & $9 \%$ & $41 \%$ \\
\hline $\begin{array}{l}\text { Ads on buses or } \\
\text { bus shelters }\end{array}$ & $14 \%$ & $20 \%$ & $9 \%$ & $15 \%$ & $7 \%$ & $5 \%$ & $8 \%$ & $10 \%$ \\
\hline $\begin{array}{l}\text { Got something in } \\
\text { the mail }\end{array}$ & $6 \%$ & $25 \%$ & $7 \%$ & $20 \%$ & $4 \%$ & $15 \%$ & $5 \%$ & $18 \%$ \\
\hline On a billboard & $13 \%$ & $11 \%$ & $5 \%$ & $18 \%$ & $3 \%$ & $6 \%$ & $4 \%$ & $11 \%$ \\
\hline Radio & $3 \%$ & $50 \%$ & $2 \%$ & $60 \%$ & $4 \%$ & $24 \%$ & $3 \%$ & $32 \%$ \\
\hline Television & $9 \%$ & $0 \%$ & $4 \%$ & $33 \%$ & $2 \%$ & $17 \%$ & $3 \%$ & $19 \%$ \\
\hline $\begin{array}{l}\text { Talked to someone } \\
\text { from [Local } \\
\text { Partner] }\end{array}$ & $4 \%$ & $100 \%$ & $2 \%$ & $80 \%$ & $1 \%$ & $40 \%$ & $1 \%$ & $69 \%$ \\
\hline $\begin{array}{l}\text { At a community } \\
\text { center of faith- } \\
\text { based organization }\end{array}$ & $7 \%$ & $0 \%$ & $1 \%$ & $0 \%$ & $1 \%$ & $0 \%$ & $1 \%$ & $0 \%$ \\
\hline Responses received & & 70 & & 24 & & 91 & & 85 \\
\hline
\end{tabular}

Bold indicates category value significantly greater or less than expected $(\mathrm{p}<0.05$, adj. stand. Chi-square residual).

In addition to the close-ended questions about where respondents had gotten information about bike share or certain experiences or exposures they had, we asked them to explain "specifically where and how they first learned about" the bike share system. We received written responses from 719 (81\%) of our survey respondents for this open-ended question. Responses were coded thematically; responses that touched on multiple themes or topics were coded into multiple groups. The results are shown in Table 5-6.

The most frequently cited ways that people first learned about bike share were from the internet (27\%), from family and friends (23\%), and from seeing the bike share bikes or stations (23\%). Notably, BBSP target users were significantly less likely to mention learning about bike share 
from friends and family (12\% compared to $23-26 \%$ of other users), and were correspondingly more likely to have learned about it from an advocacy group (either community based or citywide) or promotion (14\% compared to $3-4 \%$ for other users). While this is not surprising given that the group was defined by its participation in a BBSP program, it is an important finding. It indicates that the programs are the initial source of information for many users.

Table 5-6 Open-ended responses - How first learned about the bike share system

\begin{tabular}{|l|c|c|c|c|}
\hline \multicolumn{1}{|c|}{ Coded Response Category } & $\begin{array}{c}\text { BBSP target } \\
\text { users }\end{array}$ & $\begin{array}{c}\text { Non-BBSP target } \\
\text { users }\end{array}$ & $\begin{array}{c}\text { Higher-income } \\
\text { white users }\end{array}$ & Total \\
\hline Internet/social media & $32 \%$ & $23 \%$ & $28 \%$ & $27 \%$ \\
\hline Friend/family/co-worker & $\mathbf{1 2 \%}$ & $26 \%$ & $23 \%$ & $23 \%$ \\
\hline Seeing stations/bikes & $24 \%$ & $25 \%$ & $22 \%$ & $23 \%$ \\
\hline Unspecified news source & $14 \%$ & $9 \%$ & $15 \%$ & $13 \%$ \\
\hline Familiar with bike share elsewhere & $3 \%$ & $4 \%$ & $6 \%$ & $6 \%$ \\
\hline Advocacy group/promotion & $\mathbf{1 4}$ & $3 \%$ & $4 \%$ & $4 \%$ \\
\hline School/work & $7 \%$ & $6 \%$ & $4 \%$ & $4 \%$ \\
\hline Newspaper/magazine & $7 \%$ & $2 \%$ & $3 \%$ & $3 \%$ \\
\hline Radio & $2 \%$ & $1 \%$ & $2 \%$ & $2 \%$ \\
\hline Ads & $3 \%$ & $4 \%$ & $1 \%$ & $2 \%$ \\
\hline Word of mouth & $3 \%$ & $3 \%$ & $3 \%$ & $3 \%$ \\
\hline Gathering/event & $3 \%$ & $1 \%$ & $2 \%$ & $2 \%$ \\
\hline TV news & $5 \%$ & $0 \%$ & $0 \%$ & $1 \%$ \\
\hline Don't remember & $8 \%$ & $9 \%$ & $12 \%$ & $11 \%$ \\
\hline Responses received & 59 & 186 & 474 & 719 \\
\hline
\end{tabular}

Bold indicates category value significantly greater or less than expected ( $<<0.05$, adj. stand. Chi-square residual).

\subsubsection{Experiences with bike share}

Respondents were asked about whether they had participated in any of a number of bike sharerelated activities prior to becoming bike share members. As with the sources of information, people could select all that apply (or none) from among the list of options shown in Table 5-7. If they selected an option, they were asked to rate the importance of that experience in their decision to become a member (on a scale from not important, somewhat important, important or very important, along with the option of "not sure"). The following tables present findings for all respondents that "selected" a specific choice and for those rating that choice as "very important."

The most commonly selected experiences from the list included noticing a bike share station or kiosk near their home (60\%); having friends or family who used bike share (43\%); paying to ride a bike share bike - e.g., prior to becoming a full member (29\%); using a bike share bike in another system (27\%); and finding out they qualified for a discounted membership or pass (26\%). 
BBSP target users were both much more likely to have learned that they qualify for a discount (63\%) and to rate that as very important in their decision to join bike share (93\% of those who found out they qualified said so). The BBSP target users were also much less likely to have previously used bike share in another place (only $16 \%$ said so, compared to an average of $27 \%$ of all users).

Table 5-7 Bike share exposures, and stated importance in decision to become a bike share member

\begin{tabular}{|c|c|c|c|c|c|c|c|c|}
\hline & \multicolumn{2}{|c|}{ BBSP target users } & \multicolumn{2}{|c|}{$\begin{array}{c}\text { Non-BBSP target } \\
\text { users }\end{array}$} & \multicolumn{2}{|c|}{$\begin{array}{l}\text { Higher-income, } \\
\text { white users }\end{array}$} & \multicolumn{2}{|c|}{ All } \\
\hline & Selected & \begin{tabular}{c|} 
Of those, \\
\% rating \\
"Very \\
Important"
\end{tabular} & Selected & $\begin{array}{l}\text { Of those, } \\
\text { \% rating } \\
\text { "Very } \\
\text { Important" }\end{array}$ & Selected & $\begin{array}{l}\text { Of those, } \\
\text { \% rating } \\
\text { "Very } \\
\text { Important" }\end{array}$ & Selected & $\begin{array}{l}\text { Of those, } \\
\text { \% rating } \\
\text { "Very } \\
\text { Important" }\end{array}$ \\
\hline $\begin{array}{l}\text { Noticed a [BssName] } \\
\text { station/kiosk near your } \\
\text { home }\end{array}$ & $66 \%$ & $57 \%$ & $66 \%$ & $56 \%$ & $58 \%$ & $62 \%$ & $60 \%$ & $60 \%$ \\
\hline $\begin{array}{l}\text { Had friends or family that } \\
\text { used [BssName] }\end{array}$ & $37 \%$ & $27 \%$ & $42 \%$ & $39 \%$ & $43 \%$ & $40 \%$ & $43 \%$ & $39 \%$ \\
\hline $\begin{array}{l}\text { Rode a [BssName] bike that } \\
\text { you paid to use }\end{array}$ & $20 \%$ & $36 \%$ & $29 \%$ & $50 \%$ & $30 \%$ & $40 \%$ & $29 \%$ & $43 \%$ \\
\hline $\begin{array}{l}\text { Used a bike share bike from } \\
\text { another system (not } \\
\text { [BssName]) }\end{array}$ & $16 \%$ & $18 \%$ & $23 \%$ & $37 \%$ & $29 \%$ & $38 \%$ & $27 \%$ & $37 \%$ \\
\hline $\begin{array}{l}\text { Found out you qualified for } \\
\text { a discounted membership or } \\
\text { pass }\end{array}$ & $63 \%$ & $93 \%$ & $25 \%$ & $72 \%$ & $22 \%$ & $58 \%$ & $26 \%$ & $68 \%$ \\
\hline $\begin{array}{l}\text { Talked to someone who } \\
\text { worked for [BssName] }\end{array}$ & $13 \%$ & $44 \%$ & $3 \%$ & $33 \%$ & $9 \%$ & $22 \%$ & $7 \%$ & $26 \%$ \\
\hline $\begin{array}{l}\text { Rode a [BssName] bike } \\
\text { using a free coupon }\end{array}$ & $4 \%$ & $33 \%$ & $9 \%$ & $60 \%$ & $6 \%$ & $54 \%$ & $7 \%$ & $55 \%$ \\
\hline $\begin{array}{l}\text { Rode a [BssName] bike that } \\
\text { someone else checked out } \\
\text { for you }\end{array}$ & $3 \%$ & $50 \%$ & $7 \%$ & $25 \%$ & $7 \%$ & $35 \%$ & $7 \%$ & $33 \%$ \\
\hline $\begin{array}{l}\text { Followed [BssName] on } \\
\text { Instagram, Twitter, } \\
\text { Facebook or email }\end{array}$ & $7 \%$ & $60 \%$ & $5 \%$ & $25 \%$ & $6 \%$ & $19 \%$ & $6 \%$ & $24 \%$ \\
\hline $\begin{array}{l}\text { Attended a special event } \\
\text { related to [BssName] }\end{array}$ & $1 \%$ & $100 \%$ & $5 \%$ & $8 \%$ & $5 \%$ & $27 \%$ & $5 \%$ & $23 \%$ \\
\hline $\begin{array}{l}\text { Rode a [BssName] bike at } \\
\text { an event }\end{array}$ & $1 \%$ & $0 \%$ & $4 \%$ & $40 \%$ & $4 \%$ & $32 \%$ & $4 \%$ & $33 \%$ \\
\hline $\begin{array}{l}\text { Heard about an organized } \\
\text { [BssName] ride that you } \\
\text { could join }\end{array}$ & $3 \%$ & $50 \%$ & $3 \%$ & $14 \%$ & $1 \%$ & $29 \%$ & $2 \%$ & $25 \%$ \\
\hline $\begin{array}{l}\text { Went on an organized bike } \\
\text { ride where you learned } \\
\text { about [BssName] }\end{array}$ & $3 \%$ & $0 \%$ & $3 \%$ & $33 \%$ & $1 \%$ & $67 \%$ & $2 \%$ & $43 \%$ \\
\hline Responses received & & 70 & & 24 & & 91 & & 85 \\
\hline
\end{tabular}

Bold indicates category value significantly greater or less than expected $(\mathrm{p}<0.05$, adj. stand. Chi-square residual). [BssName] is used as a place holder for the specific name of the city bike share program used in the surveys. 


\subsection{CANCELATIONS AND RENEWALS}

Several questions pertained to users who indicated that they had not renewed their bike share membership, or were considering not renewing.

\subsubsection{Past members}

For people who indicated that they were members in the past, but were not currently, we asked them to "briefly describe why you are no longer" a bike share member or pass holder. We coded the open responses into themes (Table 5-8). Cost was the most cited reason amongst all respondents, though higher-income, white users were significantly less likely to cite this (only $24 \%$ of them did), while between half and two-thirds of other users mentioned cost as a reason for not continuing. Lack of convenient stations where users wanted to go was mentioned by $22 \%$ of respondents, followed by moving to another area not served by bike share (18\%). The latter was only mentioned by users in the higher-income, white group. Other reasons included not using bike share enough to justify the membership (13\%), preferring to ride their own bike (13\%), and weather or seasonal concerns (11\%). A few others mentioned concerns with the bike share program (availability of bikes, charges, etc.); merely letting the membership lapse; health concerns; not needing the bike any longer; and concerns about the quality of the bike.

Table 5-8 Past users' reasons for no longer being a member/not renewing

\begin{tabular}{|l|c|c|c|c|}
\hline \multicolumn{1}{|c|}{ Coded Response Category } & $\begin{array}{c}\text { BBSP target } \\
\text { (past) users }\end{array}$ & $\begin{array}{c}\text { Non-BBSP target } \\
\text { (past) users }\end{array}$ & $\begin{array}{c}\text { Higher- } \\
\text { income, white } \\
\text { (past) users }\end{array}$ & $\begin{array}{c}\text { Total (past) } \\
\text { users }\end{array}$ \\
\hline Cost & $50 \%$ & $67 \%$ & $\mathbf{2 4 \%}$ & $32 \%$ \\
\hline Lack of convenient stations & $8 \%$ & $17 \%$ & $26 \%$ & $22 \%$ \\
\hline Moved/moving & $0 \%$ & $0 \%$ & $\mathbf{2 4} \%$ & $18 \%$ \\
\hline Didn't use it enough & $0 \%$ & $0 \%$ & $17 \%$ & $13 \%$ \\
\hline Own bike & $17 \%$ & $17 \%$ & $12 \%$ & $13 \%$ \\
\hline Weather & $0 \%$ & $17 \%$ & $12 \%$ & $11 \%$ \\
\hline Program flaws & $0 \%$ & $0 \%$ & $10 \%$ & $8 \%$ \\
\hline Lapsed & $17 \%$ & $0 \%$ & $5 \%$ & $7 \%$ \\
\hline Health & $8 \%$ & $0 \%$ & $2 \%$ & $3 \%$ \\
\hline No longer needed it & $0 \%$ & $0 \%$ & $2 \%$ & $1 \%$ \\
\hline Bike quality & $0 \%$ & $17 \%$ & $0 \%$ & $1 \%$ \\
\hline Responses received & 12 & 6 & 58 & 76 \\
\hline
\end{tabular}

Bold indicates category value significantly greater or less than expected $(\mathrm{p}<0.05$, adj. stand. Chi-square residual).

A follow-up question asked the people who were no longer members, what might "cause you to rejoin?" Respondents could select from among five options, or list some other option. The percentage of respondents selecting each option are shown in Table 5-9. Two-thirds indicated that a discount might get them to rejoin, while half indicated that more stations where they need 
them might cause them to rejoin. A smaller percentage indicated that more safe places to ride could get them to rejoin (17\%), while another $15 \%$ said that they planned to rejoin when the weather improved. Most notably, only 1\% (one person) indicated that they were done with bike share completely.

A quarter of these respondents wrote in other reasons for quitting the bike share program. A number of those people wrote in reasons why they quit, including having moved and health issues. Several other people provided suggestions for making the bikes easy or more comfortable to ride, and addressing perceived issues with the system operation. Several indicated that they would use bike share when they were with other people who wanted to use it (such as visitors to town), or that better family accommodations would help.

Table 5-9 Past users: What might cause you to rejoin bike share

\begin{tabular}{|l|c|c|c|c|}
\hline \multicolumn{1}{|c|}{ Option } & $\begin{array}{c}\text { BBSP target } \\
\text { (past) users }\end{array}$ & $\begin{array}{c}\text { Non-BBSP target } \\
\text { (past) users }\end{array}$ & $\begin{array}{c}\text { Higher- } \\
\text { income, white } \\
\text { (past) users }\end{array}$ & $\begin{array}{c}\text { Total } \\
\text { (past) } \\
\text { users }\end{array}$ \\
\hline A discount & $83 \%$ & $83 \%$ & $62 \%$ & $67 \%$ \\
\hline More stations where I need them & $42 \%$ & $50 \%$ & $47 \%$ & $47 \%$ \\
\hline If there were more safe places to ride & $8 \%$ & $33 \%$ & $17 \%$ & $17 \%$ \\
\hline $\begin{array}{l}\text { Weather only - I'm planning to re-purchase } \\
\text { my pass in the spring }\end{array}$ & $8 \%$ & $17 \%$ & $17 \%$ & $15 \%$ \\
\hline Nothing, I'm done & $0 \%$ & $0 \%$ & $2 \%$ & $1 \%$ \\
\hline Other & $25 \%$ & $17 \%$ & $24 \%$ & $24 \%$ \\
\hline Responses received & 12 & 6 & $58-60$ & $76-78$ \\
\hline
\end{tabular}

\subsubsection{Current members}

All current bike share members or pass holders were asked to indicate how likely they were to renew their current membership. As shown in Table 5-10, two-thirds told us that they were "very likely" to renew, with no significant differences between the three groups, and another $22 \%$ saying they were "likely" to renew. Thirteen percent were either undecided or unlikely to renew, and the BBSP target users were a bit overrepresented in this group and underrepresented in those "likely" to renew, indicating some higher level of indecision.

Table 5-10 Likelihood of renewing current membership

\begin{tabular}{|l|c|c|c|c|}
\hline & $\begin{array}{c}\text { BBSP target } \\
\text { users }\end{array}$ & Non-BBSP target users & $\begin{array}{c}\text { Higher-income, } \\
\text { white users }\end{array}$ & Total \\
\hline Very likely & $64 \%$ & $61 \%$ & $67 \%$ & $65 \%$ \\
\hline Likely & $\mathbf{1 1 \%}$ & $22 \%$ & $23 \%$ & $22 \%$ \\
\hline Undecided & $\mathbf{1 8 \%}$ & $\mathbf{1 3 \%}$ & $\mathbf{7 \%}$ & $10 \%$ \\
\hline Unlikely & $2 \%$ & $1 \%$ & $1 \%$ & $1 \%$ \\
\hline Very unlikely & $\mathbf{5 \%}$ & $2 \%$ & $2 \%$ & $2 \%$ \\
\hline Responses received & 56 & 218 & 530 & 804 \\
\hline
\end{tabular}

Bold indicates category value significantly greater or less than expected $(\mathrm{p}<0.05$, adj. stand. Chi-square residual). 
A follow-up question asked everyone who was either undecided or unlikely to renew to briefly describe why that was the case. Coded responses are shown in Table 5-11. The cost of renewing was mentioned by a third of the 99 people who indicated they were not sure or not likely to renew. Those in the BBSP target user group were more likely to mention cost, with $60 \%$ doing so. A fifth of these respondents indicated that they moved to a place where it did not make sense to renew. Around $15 \%$ indicated that they were not using bike share enough or that the bike share stations were not in convenient places for them.

Among the remaining reasons, BBSP target users were a bit more likely to mention the time limits as being a frustration for them.

Table 5-11 Undecided or unlikely to renew - Explanation of why

\begin{tabular}{|c|c|c|c|c|}
\hline Coded Response Category & $\begin{array}{l}\text { BBSP target } \\
\text { users }\end{array}$ & $\begin{array}{l}\text { Non-BBSP } \\
\text { target users }\end{array}$ & $\begin{array}{l}\text { Higher-income, } \\
\text { white users }\end{array}$ & Total \\
\hline Cost & $60 \%$ & $35 \%$ & $26 \%$ & $34 \%$ \\
\hline Moved/moving & $7 \%$ & $15 \%$ & $26 \%$ & $19 \%$ \\
\hline Not using it enough & $7 \%$ & $12 \%$ & $22 \%$ & $16 \%$ \\
\hline Lack of convenient stations & $7 \%$ & $15 \%$ & $18 \%$ & $15 \%$ \\
\hline Own bike & $0 \%$ & $18 \%$ & $8 \%$ & $10 \%$ \\
\hline Seasonal & $7 \%$ & $6 \%$ & $10 \%$ & $8 \%$ \\
\hline Bike/dock availability & $0 \%$ & $3 \%$ & $8 \%$ & $5 \%$ \\
\hline Time limit & $13 \%$ & $0 \%$ & $4 \%$ & $4 \%$ \\
\hline Bike quality & $0 \%$ & $3 \%$ & $4 \%$ & $3 \%$ \\
\hline Not sure/assessing & $33 \%$ & $21 \%$ & $26 \%$ & $25 \%$ \\
\hline Responses received & 15 & 34 & 50 & 99 \\
\hline
\end{tabular}

Bold indicates category value significantly greater or less than expected ( $<<0.05$, adj. stand. Chi-square residual). 


\subsection{BIKE SHARE USE}

Other questions on the survey sought to illuminate how respondents were using bike share, including how often, for what types of trips, when and why.

\subsection{BIKE SHARE TRIPS}

Respondents were asked how many trips they make by bike share in a typical month when the weather is nice. Instructions clarified that a trip was point-to-point, and that a round trip would count as two trips. Responses broken down by analysis group are shown in Table 6-1. All three groups are using bike share at similar frequencies. Just over a third of respondents indicated that they take 20 or more trips per month by bike share, and over half make 11 or more trips per month. Only $1 \%$ said no trips and $5 \%$ said one or two trips.

Table 6-1 Bike share trips in a typical month in nice weather (current members)

\begin{tabular}{|l|c|c|c|c|}
\hline & BBSP target users & Non-BBSP target users & $\begin{array}{c}\text { Higher-income, } \\
\text { white users }\end{array}$ & All \\
\hline No trips & $4 \%$ & $2 \%$ & $1 \%$ & $1 \%$ \\
\hline $1-2$ trips & $9 \%$ & $5 \%$ & $5 \%$ & $5 \%$ \\
\hline $3-5$ trips & $11 \%$ & $12 \%$ & $12 \%$ & $12 \%$ \\
\hline $6-10$ trips & $18 \%$ & $22 \%$ & $22 \%$ & $22 \%$ \\
\hline $11-19$ trips & $23 \%$ & $24 \%$ & $23 \%$ & $23 \%$ \\
\hline 20 or more trips & $36 \%$ & $34 \%$ & $37 \%$ & $36 \%$ \\
\hline Responses received & 56 & 218 & 528 & 802 \\
\hline
\end{tabular}

We also asked respondents to indicate how frequently they used bike share for various purposes, again specifying when the weather is nice. For each trip purpose category, respondents could select between never, less than once per month, 1-3 days per month, 1-2 days per week, 3-5 days per weeks, or six or more days per week. Table 6-2 shows the percentage in each analysis group selecting that they ever used bike share for that purpose (i.e., any option selected besides never), and the percentage selecting at least one day per week or more.

Shopping/errands, social/recreational, trips to and from public transit, and commute trips were selected by about $80 \%$ or more of the respondents as a trip purpose for them at least once. Twothirds had used bike share to get to meals, about half had used it for family or personal business, or for exercise, and over a third had used it to for a medical-related trip. Just $13 \%$ indicated that they used it for school or daycare, and $11 \%$ for looking for work. In terms of the trip purposes taken more frequently, just over half the respondents indicated that they use bike share for commuting at least once per week, followed by $43 \%$ selecting getting to or from public transit, $37 \%$ for social or recreational trips, and 31\% for shopping and errands. 
BBSP target users were more likely to have used bike share just to get out for a ride or for exercise - both ever, but also more regularly, with $30 \%$ in this group saying they used bike share for this purpose at least weekly. This is consistent with our findings from the resident survey that found that exercise and fun were leading reasons why lower-income people of color were interested in using bike share. Respondents in this group were also more likely to use bike share for school, daycare or religious-related trips, as well as for trips related to looking for work or job/skill training.

Table 6-2 Trip purpose of bike share

\begin{tabular}{|c|c|c|c|c|c|c|}
\hline & \multicolumn{2}{|c|}{ BBSP target users } & \multicolumn{2}{|c|}{$\begin{array}{c}\text { Non-BBSP target } \\
\text { users }\end{array}$} & \multicolumn{2}{|c|}{$\begin{array}{l}\text { Higher-income, } \\
\text { white users }\end{array}$} \\
\hline & Ever & $\begin{array}{l}\text { At least once } \\
\text { a week }\end{array}$ & Ever & $\begin{array}{l}\text { At least once } \\
\text { a week }\end{array}$ & Ever & $\begin{array}{l}\text { At least once } \\
\text { a week }\end{array}$ \\
\hline Just out for a ride/exercise & $72 \%$ & $30 \%$ & $58 \%$ & $24 \%$ & $47 \%$ & $15 \%$ \\
\hline To/from public transit & $72 \%$ & $43 \%$ & $84 \%$ & $48 \%$ & $83 \%$ & $43 \%$ \\
\hline Work/commute & $75 \%$ & $51 \%$ & $80 \%$ & $54 \%$ & $79 \%$ & $53 \%$ \\
\hline School/daycare/religious & $30 \%$ & $20 \%$ & $20 \%$ & $12 \%$ & $13 \%$ & $6 \%$ \\
\hline Medical/dental & $35 \%$ & $7 \%$ & $33 \%$ & $5 \%$ & $38 \%$ & $3 \%$ \\
\hline Shopping/errands & $65 \%$ & $35 \%$ & $83 \%$ & $34 \%$ & $84 \%$ & $31 \%$ \\
\hline Social/recreational & $77 \%$ & $36 \%$ & $86 \%$ & $41 \%$ & $84 \%$ & $37 \%$ \\
\hline Family personal business/obligations & $49 \%$ & $21 \%$ & $52 \%$ & $24 \%$ & $56 \%$ & $20 \%$ \\
\hline Meals & $59 \%$ & $26 \%$ & $67 \%$ & $20 \%$ & $67 \%$ & $18 \%$ \\
\hline $\begin{array}{l}\text { Look for work/get to a job } \\
\text { interview/trainings }\end{array}$ & $24 \%$ & $7 \%$ & $19 \%$ & $3 \%$ & $11 \%$ & $2 \%$ \\
\hline Responses received & \multicolumn{2}{|r|}{69} & \multicolumn{2}{|r|}{224} & \multicolumn{2}{|r|}{582} \\
\hline
\end{tabular}

Bold indicates category value significantly greater or less than expected ( $<<0.05$, adj. stand. Chi-square residual).

Respondents were asked if they usually take their trips on weekdays, weekends or an even mix. Higher-income, white respondents were more likely to use bike share just weekdays, while other respondents were more likely to state it was an even mix.

Table 6-3 Days of week using bike share

\begin{tabular}{|c|c|c|c|c|}
\hline & $\begin{array}{c}\text { BBSP } \\
\text { target users* }\end{array}$ & $\begin{array}{c}\text { Non-BBSP } \\
\text { target users* }\end{array}$ & $\begin{array}{l}\text { Higher-income, } \\
\text { white users* }\end{array}$ & All \\
\hline Mostly weekdays & $31 \%$ & $29 \%$ & $43 \%$ & $39 \%$ \\
\hline Mostly weekends & $6 \%$ & $9 \%$ & $9 \%$ & $8 \%$ \\
\hline $\begin{array}{l}\text { Even mix between } \\
\text { weekdays and weekends }\end{array}$ & $57 \%$ & $54 \%$ & $44 \%$ & $47 \%$ \\
\hline Responses received & 70 & 223 & 585 & 878 \\
\hline
\end{tabular}

Bold indicates category value significantly greater or less than expected $(\mathrm{p}<0.05$, adj. stand. Chi-square residual). Difference between column sum and $100 \%$ due to respondents indicating they were "not sure".

Respondents were also asked to think about the most recent time they had used bike share, and select from a list of reasons why they chose to use bike share. Respondents could select as many 
reasons as applied or none. If they selected a reason, they were asked to indicate if they considered it to be a "minor reason," "contributing reason" or "primary reason” for using bike share. The responses are shown in Table 6-4 by analysis group, with utilitarian reasons shown on the top half of the table and other reasons shown on the bottom half of the table.

Overall, the reasons selected by the greatest percentage of respondents were that the destination was too far to walk (86\% of people said this was a reason they had used bike share), bicycling was easier or faster to their destination (77\%), they wanted to be outside on a bike (76\%), and they were going to locations not well served by transit (69\%). Of those top reasons, that bicycling was easier or faster to their destination stands out as having the greatest number of respondents tell us that this was a primary reason for their choice to use bike share (71\% said so).

In terms of differences between the analysis groups, BBSP target users were much less likely to indicate that getting to a location not well served by transit was a reason they chose bike share. However, for this group, those who did select they used bike share because they didn't have access to a car were much more likely to list this as a primary reason for choosing bike share (67\% said so, compared to $34 \%$ of all respondents). Not having a bike of their own was also much more likely to be a primary reason for BBSP target users (63\% for this group compared to $38 \%$ for all users, though the difference was not statistically significant). 
Table 6-4 Reasons for choosing bike share for a trip

\begin{tabular}{|c|c|c|c|c|c|c|c|c|c|}
\hline & & \multicolumn{2}{|c|}{$\begin{array}{l}\text { BBSP target } \\
\text { users }\end{array}$} & \multicolumn{2}{|c|}{$\begin{array}{l}\text { Non-BBSP } \\
\text { target users }\end{array}$} & \multicolumn{2}{|c|}{$\begin{array}{l}\text { Higher-income, } \\
\text { white users }\end{array}$} & \multicolumn{2}{|c|}{ All } \\
\hline & & 芯 & $\begin{array}{l}\text { Of those, } \\
\text { \% rating } \\
\text { "Primary } \\
\text { Reason" }\end{array}$ & 芯 & $\begin{array}{l}\text { Of those, } \\
\text { \% rating } \\
\text { "Primary } \\
\text { Reason" }\end{array}$ & 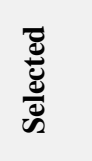 & $\begin{array}{l}\text { Of those, } \\
\text { \% rating } \\
\text { "Primary } \\
\text { Reason" }\end{array}$ & 总 & $\begin{array}{l}\text { Of those, } \\
\text { \% rating } \\
\text { "Primary } \\
\text { Reason" }\end{array}$ \\
\hline \multirow{12}{*}{ 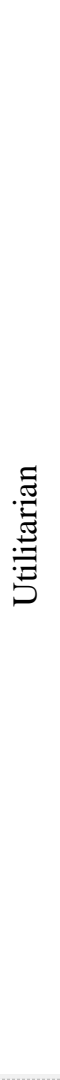 } & Too far to walk & $84 \%$ & $53 \%$ & $86 \%$ & $49 \%$ & $87 \%$ & $46 \%$ & $86 \%$ & $47 \%$ \\
\hline & $\begin{array}{l}\text { Bicycle is faster/easier to } \\
\text { that destination }\end{array}$ & $67 \%$ & $77 \%$ & $75 \%$ & $70 \%$ & $79 \%$ & $71 \%$ & $77 \%$ & $71 \%$ \\
\hline & $\begin{array}{l}\text { Going to locations not well } \\
\text { served by public transit }\end{array}$ & $43 \%$ & $53 \%$ & $64 \%$ & $47 \%$ & $74 \%$ & $50 \%$ & $69 \%$ & $49 \%$ \\
\hline & $\begin{array}{l}\text { Bike share stations near } \\
\text { home/work/school }\end{array}$ & $50 \%$ & $54 \%$ & $67 \%$ & $61 \%$ & $59 \%$ & $53 \%$ & $60 \%$ & $55 \%$ \\
\hline & $\begin{array}{l}\text { Bicycle is cheaper than } \\
\text { other alternatives }\end{array}$ & $57 \%$ & $50 \%$ & $60 \%$ & $45 \%$ & $57 \%$ & $40 \%$ & $58 \%$ & $42 \%$ \\
\hline & $\begin{array}{l}\text { Needed/wanted one-way } \\
\text { trip }\end{array}$ & $53 \%$ & $54 \%$ & $55 \%$ & $53 \%$ & $59 \%$ & $51 \%$ & $57 \%$ & $52 \%$ \\
\hline & $\begin{array}{l}\text { Travelling at time when } \\
\text { public transit is not running } \\
\text { (or not running frequently) }\end{array}$ & $39 \%$ & $37 \%$ & $48 \%$ & $45 \%$ & $46 \%$ & $36 \%$ & $46 \%$ & $38 \%$ \\
\hline & $\begin{array}{l}\text { Don't have to use a bike of } \\
\text { my own }\end{array}$ & $27 \%$ & $63 \%$ & $40 \%$ & $41 \%$ & $36 \%$ & $35 \%$ & $37 \%$ & $38 \%$ \\
\hline & Don't have access to a car & $39 \%$ & $67 \%$ & $40 \%$ & $33 \%$ & $29 \%$ & $29 \%$ & $33 \%$ & $34 \%$ \\
\hline & Too much traffic & $27 \%$ & $42 \%$ & $33 \%$ & $29 \%$ & $30 \%$ & $28 \%$ & $31 \%$ & $30 \%$ \\
\hline & $\begin{array}{l}\text { Don't have to store/access } \\
\text { my bike at home }\end{array}$ & $26 \%$ & $44 \%$ & $27 \%$ & $40 \%$ & $27 \%$ & $41 \%$ & $27 \%$ & $41 \%$ \\
\hline & $\begin{array}{l}\text { Parking is } \\
\text { limited/expensive }\end{array}$ & $26 \%$ & $56 \%$ & $22 \%$ & $33 \%$ & $27 \%$ & $31 \%$ & $26 \%$ & $33 \%$ \\
\hline \multirow{6}{*}{ 壱 } & $\begin{array}{l}\text { Nice weather/wanted to be } \\
\text { outside/just like biking }\end{array}$ & $69 \%$ & $38 \%$ & $75 \%$ & $48 \%$ & $78 \%$ & $44 \%$ & $76 \%$ & $45 \%$ \\
\hline & Wanted to get exercise & $51 \%$ & $47 \%$ & $57 \%$ & $51 \%$ & $55 \%$ & $38 \%$ & $55 \%$ & $42 \%$ \\
\hline & To help the environment & $30 \%$ & $43 \%$ & $33 \%$ & $29 \%$ & $41 \%$ & $31 \%$ & $38 \%$ & $31 \%$ \\
\hline & $\begin{array}{l}\text { Just wanted to try biking } \\
\text { for certain trips }\end{array}$ & $21 \%$ & $27 \%$ & $31 \%$ & $46 \%$ & $21 \%$ & $26 \%$ & $24 \%$ & $33 \%$ \\
\hline & Don't like to drive & $14 \%$ & $50 \%$ & $14 \%$ & $26 \%$ & $19 \%$ & $26 \%$ & $17 \%$ & $28 \%$ \\
\hline & Friends wanted to bicycle & $7 \%$ & $20 \%$ & $14 \%$ & $47 \%$ & $14 \%$ & $33 \%$ & $14 \%$ & $36 \%$ \\
\hline
\end{tabular}

Bold indicates category value significantly greater or less than expected $(\mathrm{p}<0.05$, adj. stand. Chi-square residual).

\subsection{HOW TO INCREASE BIKE SHARE USE}

A section asked if certain changes would make respondents more likely to use bike share. For each suggested change, respondents could indicate if the change would make them "no more 
likely” to use bike share, "somewhat more likely,” or “much more likely,” along with an option to select “does not apply.” Results by analysis group are shown in Table 6-5.

Four in five respondents indicated that more bike share stations would make them much more likely to use bike share, with no differences between the groups. Nearly three-quarters indicated that better bike routes connecting the stations would make them much more likely to use bike share. Following those two, a group of changes received around half of respondents selecting much more likely, including more docks or bikes at existing stations, more stations close together, longer time limits, and help finding a safe way to get where they need to go.

Target users (whether BBSP or not) were more likely to indicate that longer time limits would make them more likely to use bike share. White, higher-income users were also less likely to select help finding safe routes, riding with more friends or family, lower overage fees, free or low-cost gear, and organized rides as changes that would make them more likely to use bike share.

Table 6-5 Changes to increase bike share use

\begin{tabular}{|c|c|c|c|c|}
\hline Percent “Much more likely” & $\begin{array}{l}\text { BBSP target } \\
\text { users }\end{array}$ & $\begin{array}{c}\text { Non-BBSP target } \\
\text { users }\end{array}$ & $\begin{array}{c}\text { Higher- } \\
\text { income, white } \\
\text { users }\end{array}$ & Total \\
\hline $\begin{array}{l}\text { More [BssName] stations where I want to } \\
\text { go }\end{array}$ & $79 \%$ & $83 \%$ & $80 \%$ & $81 \%$ \\
\hline $\begin{array}{l}\text { Better bike routes (e.g., bike lanes or trails) } \\
\text { that connect [BssName] stations }\end{array}$ & $69 \%$ & $76 \%$ & $70 \%$ & $72 \%$ \\
\hline More docks or bikes at existing stations & $54 \%$ & $57 \%$ & $56 \%$ & $56 \%$ \\
\hline More [BssName] stations close together & $49 \%$ & $55 \%$ & $52 \%$ & $52 \%$ \\
\hline Longer time limits for checking out bikes & $63 \%$ & $56 \%$ & $44 \%$ & $48 \%$ \\
\hline $\begin{array}{l}\text { Help finding safe ways to get where I need } \\
\text { to go }\end{array}$ & $48 \%$ & $56 \%$ & $43 \%$ & $47 \%$ \\
\hline $\begin{array}{l}\text { If more of my friends or family could use } \\
\text { [BssName] with me }\end{array}$ & $37 \%$ & $43 \%$ & $30 \%$ & $34 \%$ \\
\hline Lower fees for keeping a bike out too long & $42 \%$ & $43 \%$ & $29 \%$ & $34 \%$ \\
\hline $\begin{array}{l}\text { Access to free or low-cost helmets and } \\
\text { other gear }\end{array}$ & $29 \%$ & $31 \%$ & $23 \%$ & $25 \%$ \\
\hline Organized rides for people like me & $17 \%$ & $15 \%$ & $5 \%$ & $8 \%$ \\
\hline Min. number of responses ${ }^{1}$ & 58 & 203 & 545 & 814 \\
\hline Max. number of responses ${ }^{1}$ & 68 & 222 & 583 & 873 \\
\hline
\end{tabular}

Respondents were then asked to describe one thing that would make them more likely to use the bike share system, and were provided space to type in their response. We received written comments from 735 people, and coded them into thematic categories. Some responses were coded into multiple categories if they touched on multiple themes. 
Nearly half of all respondents indicated that system expansions or more stations would make them more likely to use bike share. Following that were more bikes (21\%), better bike routes and infrastructure (16\%), longer time limits (9\%), and better bikes (9\%). Although only mentioned by $5 \%$ of all respondents, BBSP target users were more likely to list lower cost as something that would make them more likely to use bike share (16\% did so).

Table 6-6 Open-ended responses to increasing bike share use

\begin{tabular}{|l|c|c|c|c|}
\hline \multicolumn{1}{|c|}{ Coded Response Category } & $\begin{array}{c}\text { BBSP target } \\
\text { users }\end{array}$ & $\begin{array}{c}\text { Non-BBSP target } \\
\text { users }\end{array}$ & $\begin{array}{c}\text { Higher-income, } \\
\text { white users }\end{array}$ & Total \\
\hline Expansion/more stations & $41 \%$ & $46 \%$ & $48 \%$ & $47 \%$ \\
\hline Better circulation/more bikes & $12 \%$ & $17 \%$ & $\mathbf{2 4 \%}$ & $21 \%$ \\
\hline Better bike infrastructure & $10 \%$ & $15 \%$ & $16 \%$ & $16 \%$ \\
\hline Time limit & $12 \%$ & $10 \%$ & $8 \%$ & $9 \%$ \\
\hline Bike quality & $12 \%$ & $9 \%$ & $8 \%$ & $9 \%$ \\
\hline Cost & $\mathbf{1 6 \%}$ & $6 \%$ & $\mathbf{4 \%}$ & $5 \%$ \\
\hline Improved app/info & $3 \%$ & $4 \%$ & $4 \%$ & $4 \%$ \\
\hline Membership terms & $2 \%$ & $5 \%$ & $3 \%$ & $3 \%$ \\
\hline Safety & $2 \%$ & $4 \%$ & $4 \%$ & $4 \%$ \\
\hline Helmet/gear & $3 \%$ & $3 \%$ & $3 \%$ & $3 \%$ \\
\hline Enforcement & $3 \%$ & $4 \%$ & $2 \%$ & $3 \%$ \\
\hline Better customer service & $2 \%$ & $2 \%$ & $1 \%$ & $1 \%$ \\
\hline Frequent/satisfied user & $2 \%$ & $2 \%$ & $2 \%$ & $2 \%$ \\
\hline Other & $0 \%$ & $2 \%$ & $1 \%$ & $1 \%$ \\
\hline Responses received & 58 & 185 & 492 & 735 \\
\hline
\end{tabular}

Bold indicates category value significantly greater or less than expected ( $<<0.05$, adj. stand. Chi-square residual).

\subsection{MODES REPLACED BY BIKE SHARE}

We asked respondents to think about their bike share trips and consider how they would have made those trips if bike share were not available. We asked respondents to assign a percentage to each of six other modes (including an "other” option), along with "wouldn’t have made the trip at all" and adding up to a total of $100 \%$ of their bike share trips. Table 6-7 shows the average allocation by analysis group. To explore whether more intensive bike share users (those taking a greater number of trips by bike share) might exhibit different mode replacement trends, we also present the breakdown by the number of trips reported by the user (for a typical month).

Based on the mean responses across our respondents, just over two in five trips replaced transit trips and a quarter replaced walk trips, generally consistent with existing research (Buck et al. 2013; Shaheen et al. 2012). Twelve percent took the place of personal bike trips, while 11\% substituted for taxi, ride-hailing or car sharing trips. Other trip types included driving a personal vehicle (4\%), and getting a ride from friends or family (just $1 \%$ ). Overall, $4 \%$ said they would not have made the trip without bike share. There was striking parity between the analysis groups 
on the modes substituted for by bike share. There were no significant differences for public transit, walking, personal bike or driving a personal car (ANOVA, $\mathrm{p}<0.05$ ). BBSP target users were, however, less likely to substitute for taxi, ride-hailing or car sharing trips than the other groups. Though the percentages were low for all groups, two other categories revealed significant differences: both the lower-income/people of color groups were more likely to say they would have gotten a ride from friends and family and BBSP target users were also more likely to say they would not have made the trip at all without bike share. Both of these findings suggest that bike share may be providing some individuals with new, independent mobility options.

There was similarly a great deal of parity in the distribution across users of varying intensities of bike share use. Those who reported no trips in a typical month (but might still use bike share occasionally) were a bit less likely to report bike share substituting for public transit or taxi trips.

Table 6-7 Modes replaced, mean percentage of trips

\begin{tabular}{|c|c|c|c|c|c|c|c|c|}
\hline & $\begin{array}{l}\text { Public } \\
\text { transit }\end{array}$ & Walk & $\begin{array}{l}\text { Persona } \\
\text { l bicycle }\end{array}$ & $\begin{array}{c}\text { Taxi/Uber/ } \\
\text { Lyft /car } \\
\text { share }\end{array}$ & $\begin{array}{c}\text { Drive } \\
\text { personal } \\
\text { vehicle }\end{array}$ & $\begin{array}{l}\text { Would not } \\
\text { have made } \\
\text { the trip }\end{array}$ & $\begin{array}{l}\text { Ride from } \\
\text { a friend or } \\
\text { family }\end{array}$ & n \\
\hline \multicolumn{9}{|c|}{ Target and demographic group } \\
\hline BBSP target users & 41 & 25 & 12 & 7 & 6 & 7 & 3 & 70 \\
\hline $\begin{array}{l}\text { Non-BBSP target } \\
\text { users }\end{array}$ & 41 & 25 & 11 & 11 & 5 & 4 & 2 & 224 \\
\hline $\begin{array}{l}\text { Higher-income, } \\
\text { white users }\end{array}$ & 41 & 27 & 13 & 12 & 4 & 3 & 1 & 589 \\
\hline All & 41 & 26 & 12 & 11 & 4 & 4 & 1 & 883 \\
\hline \multicolumn{9}{|c|}{ Bike share trips in typical month ${ }^{2}$} \\
\hline No trips & $33 \%$ & $23 \%$ & $20 \%$ & $8 \%$ & $8 \%$ & $9 \%$ & $1 \%$ & 48 \\
\hline 1-2 trips & $39 \%$ & $21 \%$ & $10 \%$ & $12 \%$ & $11 \%$ & $4 \%$ & $2 \%$ & 102 \\
\hline 3-5 trips & $39 \%$ & $26 \%$ & $11 \%$ & $11 \%$ & $6 \%$ & $5 \%$ & $2 \%$ & 153 \\
\hline $6-10$ trips & $37 \%$ & $25 \%$ & $13 \%$ & $13 \%$ & $6 \%$ & $4 \%$ & $2 \%$ & 258 \\
\hline 11-19 trips & $39 \%$ & $27 \%$ & $14 \%$ & $11 \%$ & $5 \%$ & $4 \%$ & $1 \%$ & 259 \\
\hline 20 or more trips & $43 \%$ & $27 \%$ & $13 \%$ & $10 \%$ & $2 \%$ & $4 \%$ & $1 \%$ & 390 \\
\hline All & $40 \%$ & $26 \%$ & $13 \%$ & $11 \%$ & $5 \%$ & $4 \%$ & $1 \%$ & 1210 \\
\hline
\end{tabular}

\subsection{SPENDING AND EXERCISE}

A section of the survey sought to understand if using bike share was affecting respondents' spending on transportation or exercise/health-related costs. A question asked if, for each of several categories of potential costs, they were spending much more, more, about the same, less or much less. "Does not apply” was also an option. A follow-up question asked how much they think they save on travel on a weekly basis through using bike share. Finally, we also asked if 
respondents get more or less exercise as a result of using bike share. Responses by analysis groups are shown in Table 6-8.

Just under half of the respondents indicated that they were spending less or much less on public transit as a result of using bike share. A quarter were spending less on driving a personal car and $59 \%$ were spending less on taxis, ride-hailing and car sharing. Few in any of these categories said they were spending more; most of those who were not spending less said they were either spending about the same, or selected “does not apply.” In terms of transportation overall, 54\% said they were spending less, and 7\% said they were spending more (mostly in the higherincome, white group). Eighteen percent of BBSP target users said they were spending much less, compared to $12 \%$ of non-BBSP target uses and $11 \%$ of higher-income, white users.

We also asked respondents how much, if any, money they were saving on travel compared to before they began using bike share. A quarter of the BBSP target users indicated that they saved \$21 or more dollars per week as a result of using bike share, which was significantly more than the $11-12 \%$ of other users ( $p<0.05)$. A majority of BBSP target users $(54 \%)$ estimated they were saving more than $\$ 5$ each month. Since the discounts ranged from about \$4-\$8 a month at the time of our study, our findings suggest that the value to recipients outweighs the (face value) subsidy provided by these programs.

To better understand how bike share was reducing travel budgets for some riders, and particularly within target analysis populations, we examined reported travel savings by modes replaced. Those reporting higher savings across all groups were replacing larger shares of ride hailing (taxi/Uber/Lyft) and rides from friends and family, and smaller shares of walk trips ( $\mathrm{p}<$ 0.05).

Relatively few people indicated that they changed any spending on exercise classes or gym memberships ( $9 \%$ total said they did, with nearly all of those saying they spent less), or health care (only $5 \%$ said they did, with $4.5 \%$ of those saying they spent less). BBSP target users were somewhat, though not significantly, more likely to say they were spending less on exercise classes or gym memberships (12\% compared to $8-9 \%$ of other users). However, they were significantly more likely to report spending less on health care - $16 \%$ compared to 3-4\% said they were spending less. Possibly related, BBSP target users were more likely to state that they were getting more exercise, with $18 \%$ stating that they were getting much more exercise, compared to $10-14 \%$ of other users. 
Table 6-8 Change in spending and exercise

\begin{tabular}{|c|c|c|c|c|}
\hline & $\begin{array}{l}\text { BBSP target } \\
\text { users }\end{array}$ & $\begin{array}{l}\text { Non-BBSP target } \\
\text { users }\end{array}$ & $\begin{array}{l}\text { Higher-income, } \\
\text { white users }\end{array}$ & All \\
\hline \multicolumn{5}{|c|}{ As a result of using bike share, percent spending less or much less on ... } \\
\hline Public transit (fares, passes, etc.) & $50 \%$ & $49 \%$ & $45 \%$ & $46 \%$ \\
\hline Driving a personal car (gas, parking, etc.) & $28 \%$ & $22 \%$ & $25 \%$ & $25 \%$ \\
\hline Taxi/Uber/Lyft/car share & $53 \%$ & $54 \%$ & $61 \%$ & $59 \%$ \\
\hline Transportation overall & $59 \%$ & $57 \%$ & $53 \%$ & $54 \%$ \\
\hline \multicolumn{5}{|c|}{$\begin{array}{r}\text { On a WEEKLY basis, about how much money do you think [BssName] saves you on your travel compared } \\
\text { to what you were spending before? }\end{array}$} \\
\hline$\$ 0$ & $13 \%$ & $20 \%$ & $26 \%$ & $23 \%$ \\
\hline$\$ 1-5$ & $16 \%$ & $17 \%$ & $13 \%$ & $14 \%$ \\
\hline$\$ 6-10$ & $19 \%$ & $18 \%$ & $20 \%$ & $19 \%$ \\
\hline$\$ 11-20$ & $10 \%$ & $19 \%$ & $19 \%$ & $18 \%$ \\
\hline$\$ 21$ or more & $25 \%$ & $14 \%$ & $12 \%$ & $14 \%$ \\
\hline Don't know & $17 \%$ & $12 \%$ & $11 \%$ & $12 \%$ \\
\hline \multicolumn{5}{|c|}{ As a result of using bike share, percent spending less or much less on ... } \\
\hline Exercise classes or gym membership & $12 \%$ & $9 \%$ & $8 \%$ & $8 \%$ \\
\hline Health care & $16 \%$ & $4 \%$ & $3 \%$ & $5 \%$ \\
\hline \multicolumn{5}{|c|}{ As a result of my use of [BssName], I have been getting... } \\
\hline More exercise & $60 \%$ & $55 \%$ & $59 \%$ & $58 \%$ \\
\hline Much more exercise & $18 \%$ & $14 \%$ & $10 \%$ & $12 \%$ \\
\hline More or much more exercise & $78 \%$ & $69 \%$ & $69 \%$ & $70 \%$ \\
\hline Responses received & $66-69$ & $216-223$ & $564-583$ & $843-874$ \\
\hline
\end{tabular}

\subsection{IMPORTANCE OF BIKE SHARE}

Respondents were asked to describe how the bike share system "is important to you," and were provided space to type in their response. We received written comments from 640 people, and coded them into thematic categories. Some responses were coded into multiple categories if they touched on multiple themes. Coded responses are shown in Table 6-9.

Among the top reasons cited for how bike share is important to these users were that it provides a source of exercise (22\% mentioned this), it helps them save time $(22 \%)$, it provides them with increased travel options and flexibility (21\%), is convenient and easy (17\%), and is enjoyable (14\%). 
Table 6-9 How is bike share important - Coded open-ended responses

\begin{tabular}{|c|c|c|c|c|}
\hline Coded Response Category & $\begin{array}{c}\text { BBSP target } \\
\text { users }\end{array}$ & $\begin{array}{l}\text { Non-BBSP } \\
\text { target users }\end{array}$ & $\begin{array}{l}\text { Higher-income, } \\
\text { white users }\end{array}$ & Total \\
\hline Exercise & $16 \%$ & $21 \%$ & $23 \%$ & $22 \%$ \\
\hline Saves time & $41 \%$ & $19 \%$ & $20 \%$ & $22 \%$ \\
\hline Options/flexibility & $10 \%$ & $25 \%$ & $21 \%$ & $21 \%$ \\
\hline Convenient/easy & $16 \%$ & $20 \%$ & $16 \%$ & $17 \%$ \\
\hline Enjoyable & $6 \%$ & $15 \%$ & $15 \%$ & $14 \%$ \\
\hline Saves money & $10 \%$ & $11 \%$ & $10 \%$ & $10 \%$ \\
\hline Benefits of not using/owning own bike & $10 \%$ & $5 \%$ & $12 \%$ & $10 \%$ \\
\hline Supplement/connection to transit & $16 \%$ & $6 \%$ & $11 \%$ & $10 \%$ \\
\hline Access(es) poorly served areas & $8 \%$ & $8 \%$ & $8 \%$ & $8 \%$ \\
\hline Gets people to place & $4 \%$ & $7 \%$ & $7 \%$ & $7 \%$ \\
\hline Promotes biking and biking infrastructure & $4 \%$ & $5 \%$ & $7 \%$ & $6 \%$ \\
\hline Being outdoors & $0 \%$ & $5 \%$ & $7 \%$ & $6 \%$ \\
\hline Environment/congestion & $6 \%$ & $3 \%$ & $6 \%$ & $5 \%$ \\
\hline Short trips & $2 \%$ & $2 \%$ & $7 \%$ & $5 \%$ \\
\hline Good for the city & $4 \%$ & $2 \%$ & $4 \%$ & $4 \%$ \\
\hline Other & $8 \%$ & $4 \%$ & $3 \%$ & $4 \%$ \\
\hline Responses received & 49 & 171 & 415 & 635 \\
\hline
\end{tabular}

Bold indicates category value significantly greater or less than expected ( $\mathrm{p}<0.05$, adj. stand. Chi-square residual).

A sampling of the responses from BBSP target users for why bike share is important is provided below:

- I used to bike home from my job to my old apartment. I did this partly for exercise and partly because it was faster than taking two buses to get home. I really enjoyed doing it and it definitely improved my mobility. I didn't' have a pharmacy or a grocery store near my old apartment so I would regularly Divvy to them. Also, coming home late at night I did not have to wait for an Owl bus and could instead leave as soon as I got off the train.

- I think it's a great quick option- There is not a one transportation method for me to get to work other than biking

- Divvy is fun but it really became valuable when I was able to use it to get to/from other public transportation. It helped me get home quickly because I would ride from my train station to my house. Similarly, I could get to appointments on time when I was running behind because of Divvy. It was also really nice to be able to go on a spur-of-the-moment bike ride.

- It's perfect for getting around downtown when the streets are just too crowded or when late at night and certain bus routes are no longer running. If more people rode Divvy bikes it would not only help with traffic but also the environment.

- Important because if I don't have bus fare, I can easily ride a divvy bike. 
- It's a good way to exercise while traveling to your destination.

- It allows me to travel without worrying about storage/parking.

- Just for pleasure and exercise

- Divvy is great for last-minute transit, one-way or multi-leg/-mode trips, or for times when you're not sure where you're going to need to go next (or how you'll be getting around). In those ways, it's even better than a personal bike, because you don't have to worry about how you'll secure your bike, how you'll eventually get back to your bike, get it home, etc. It's also really nice to have a low barrier to entry on bike-riding-I think that in the aggregate it probably helps to reduce the amount of motorized traffic a bit, with all the attendant benefits of that change.

- Allows me to freely move about the city without worrying about my bike getting stolen or getting stuck in bad weather.

- I use it when bus waits are too long and the stations are convenient. Occasional rides in the park but stations are not convenient. 


\subsection{BARRIERS}

This section focuses on questions about barriers to bicycling in general and using bike share specifically.

\subsection{BARRIERS TO BICYCLING IN GENERAL}

Respondents were presented with a variety of potential things that might keep them from riding a bike (or from biking more). They were asked to select all that apply, even if they were small barriers. For each of the selected barriers, the respondents were asked to specify if they were a "small barrier" or "big barrier." They were also given the options of selecting "not sure" or "not a barrier." The barriers and percentage of respondents who selected "big barrier" is shown in Table 7-1.

The top barrier to bicycling in general was that destinations were too far away to bike, selected by $29 \%$ of respondents. A second tier of barriers included concerns about traffic safety (17\% said it was a big barrier), the challenge of carrying things (15\%), and that riding could make them sweaty (15\%). Concern about having bike-appropriate clothing was cited by $9 \%$, followed by concern about messing up their hair or appearance (5\%), not knowing how to get places by bike (4\%), and the hassle of riding with kids (3\%).

For comparison, we have included a column showing the average of respondents in the resident survey (NITC-RR-884b) who selected that each barrier was a big barrier. Note that respondents to the resident survey were usually not current bicyclists or bike share users, so the difference between the two surveys provides a sense of what issues are perceived as barriers to a general population in these communities, in comparison to bike share users. Perhaps most notably, the top barrier among the general population, concerns about traffic safety, dropped from being a big barrier for $41 \%$ of resident respondents down to only $17 \%$ of bike share users. Because most of the respondents to both surveys live in similar neighborhoods, their access to bike infrastructure is similar, at least around their home. Therefore, this difference may be the result of bike share users feeling more comfortable riding on streets, rather than differences in the environment and exposure to traffic.

Other barriers were relatively consistent across the surveys, including the concerns about destinations being too far (29\% in this survey compared to $31 \%$ in the resident survey), riding a bike could make them sweaty (15\% compared to 14\%), and concern about the appropriateness of their clothing for biking ( $9 \%$ to 10\%). The remaining barriers were a bit more likely to be selected by resident survey respondents. In particular, $12 \%$ of the residents indicated that fear of harassment or crime was a big barrier, compared to none of the users surveyed. 
Table 7-1 Barriers to bicycling

\begin{tabular}{|c|c|c|c|c|c|}
\hline $\begin{array}{l}\text { Barriers to bicycling - percentage of respondents } \\
\text { selecting "big barrier" }\end{array}$ & $\begin{array}{c}\text { BBSP } \\
\text { target } \\
\text { users }\end{array}$ & $\begin{array}{l}\text { Non- } \\
\text { BBSP } \\
\text { target } \\
\text { users }\end{array}$ & $\begin{array}{c}\text { Higher- } \\
\text { income, } \\
\text { white } \\
\text { users }\end{array}$ & All & $\begin{array}{c}\text { Resident } \\
\text { Survey - } \\
\text { "Big } \\
\text { Barrier"* }\end{array}$ \\
\hline $\begin{array}{l}\text { The places that I need to go are too far away to } \\
\text { reach on a bike }\end{array}$ & $36 \%$ & $37 \%$ & $25 \%$ & $29 \%$ & $31 \%$ \\
\hline $\begin{array}{l}\text { Traffic makes riding a bike in my neighborhood } \\
\text { feel dangerous }\end{array}$ & $20 \%$ & $20 \%$ & $15 \%$ & $17 \%$ & $41 \%$ \\
\hline Carrying things on a bike is too difficult & $17 \%$ & $21 \%$ & $13 \%$ & $15 \%$ & $23 \%$ \\
\hline Riding a bike could make me sweaty & $13 \%$ & $13 \%$ & $16 \%$ & $15 \%$ & $14 \%$ \\
\hline The clothes I wear are not appropriate for biking & $6 \%$ & $9 \%$ & $9 \%$ & $9 \%$ & $10 \%$ \\
\hline Riding a bike could mess up my hair or appearance & $7 \%$ & $5 \%$ & $5 \%$ & $5 \%$ & $7 \%$ \\
\hline I don't know how to get where I need to go by bike & $4 \%$ & $5 \%$ & $3 \%$ & $4 \%$ & $8 \%$ \\
\hline Riding a bike with my kids is a hassle & $1 \%$ & $3 \%$ & $3 \%$ & $3 \%$ & $11 \%$ \\
\hline I am too out of shape to ride a bike & $1 \%$ & $2 \%$ & $1 \%$ & $1 \%$ & $6 \%$ \\
\hline $\begin{array}{l}\text { Something could go wrong with a bike (such as a } \\
\text { flat tire) }\end{array}$ & $1 \%$ & $1 \%$ & $1 \%$ & $1 \%$ & $11 \%$ \\
\hline $\begin{array}{l}\text { Riding a bike could make me a target for police } \\
\text { attention }\end{array}$ & $0 \%$ & $0 \%$ & $1 \%$ & $1 \%$ & $4 \%$ \\
\hline I am too old to ride a bike & $0 \%$ & $0 \%$ & $0 \%$ & $0 \%$ & $5 \%$ \\
\hline Biking might aggravate my personal health issues & $3 \%$ & $0 \%$ & $0 \%$ & $0 \%$ & $6 \%$ \\
\hline $\begin{array}{l}\text { My friends and family wouldn't want me to ride a } \\
\text { bike }\end{array}$ & $1 \%$ & $0 \%$ & $0 \%$ & $0 \%$ & $5 \%$ \\
\hline $\begin{array}{l}\text { Riding a bike is not viewed as a cool activity by my } \\
\text { friends }\end{array}$ & $0 \%$ & $0 \%$ & $0 \%$ & $0 \%$ & $3 \%$ \\
\hline People might think that I can't afford a car & $0 \%$ & $0 \%$ & $0 \%$ & $0 \%$ & $3 \%$ \\
\hline $\begin{array}{l}\text { Riding a bike could cause me to be harassed or a } \\
\text { victim of crime }\end{array}$ & $1 \%$ & $0 \%$ & $0 \%$ & $0 \%$ & $12 \%$ \\
\hline Responses received & 70 & 224 & 591 & 885 & $895-906$ \\
\hline
\end{tabular}

Bold indicates category value significantly greater or less than expected $(\mathrm{p}<0.05$, adj. stand. Chi-square residual).

*Note that the resident numbers presented here vary slightly from those presented in the Resident report (NITC-RR-884b). As presented here, the percentages are calculated including those who selected "does not apply" in the denominator in order to more closely match the options available in the user survey.

For several potential bicycling barriers, respondents were asked if bike share helped to overcome the barrier. Table 7-2 presents the barriers along with the percentage of all respondents who indicated that bike share helped a lot in overcoming the barriers, and the percentage of those who indicated that the item was a barrier to using bike share. For example, 22\% of all respondents said that bike share helped a lot in overcoming the barrier of not having a bike or related gear. However, when removing those who said this was not a barrier for them, $66 \%$ of the remaining respondents said bike share helped a lot with regard to this barrier. Target users (whether BBSP or not) were twice as likely as higher-income, white users (30-33\% compared to 15\%) to indicate that bike share helped them overcome the barrier of the cost of buying a bike or related gear. 
Also notably, over half of all respondents indicated that concern about not having a safe place to leave a bike at destinations was a barrier that bike share helped them overcome.

Table 7-2 Bike share impact on select barriers

\begin{tabular}{|c|c|c|c|c|c|}
\hline \multicolumn{2}{|c|}{$\begin{array}{c}\text { Percentage stating bike share helped a lot to } \\
\text { overcome a barrier }\end{array}$} & \multirow{2}{*}{$\begin{array}{c}\text { BBSP target } \\
\text { users } \\
26 \%\end{array}$} & \multirow{2}{*}{$\begin{array}{c}\text { Non-BBSP } \\
\text { target users } \\
24 \%\end{array}$} & \multirow{2}{*}{$\begin{array}{c}\begin{array}{c}\text { Higher- } \\
\text { income, } \\
\text { white users }\end{array} \\
21 \%\end{array}$} & \multirow{2}{*}{\begin{tabular}{|l|} 
Total \\
\\
$22 \%$ \\
\end{tabular}} \\
\hline I don't have a bike or & among all & & & & \\
\hline $\begin{array}{l}\text { related gear (such as } \\
\text { helmet/lock/lights) }\end{array}$ & $\begin{array}{l}\text { among those for whom } \\
\text { it was a barrier }\end{array}$ & $72 \%$ & $57 \%$ & $70 \%$ & $66 \%$ \\
\hline \multirow{2}{*}{$\begin{array}{l}\text { It is too expensive to buy a } \\
\text { bike or related gear }\end{array}$} & among all & $33 \%$ & $30 \%$ & $15 \%$ & $20 \%$ \\
\hline & $\begin{array}{l}\text { among those for whom } \\
\text { it was a barrier }\end{array}$ & $72 \%$ & $63 \%$ & $51 \%$ & $57 \%$ \\
\hline \multirow{2}{*}{$\begin{array}{l}\text { I don't have a safe place to } \\
\text { store a bike at home }\end{array}$} & among all & $35 \%$ & $35 \%$ & $27 \%$ & $30 \%$ \\
\hline & $\begin{array}{l}\text { among those for whom } \\
\text { it was a barrier }\end{array}$ & $73 \%$ & $71 \%$ & $63 \%$ & $66 \%$ \\
\hline \multirow{2}{*}{$\begin{array}{l}\text { There might not be a safe } \\
\text { place to leave a bike at the } \\
\text { places I go }\end{array}$} & among all & $59 \%$ & $58 \%$ & $49 \%$ & $52 \%$ \\
\hline & $\begin{array}{l}\text { among those for whom } \\
\text { it was a barrier }\end{array}$ & $80 \%$ & $76 \%$ & $68 \%$ & $71 \%$ \\
\hline Responses received & & 69 & 223 & 586 & 878 \\
\hline
\end{tabular}

Bold indicates category value significantly greater or less than expected ( $<<0.05$, adj. stand. Chi-square residual).

\subsection{BARRIERS TO USING BIKE SHARE MORE}

Respondents were presented with a variety of potential things that might keep them from using bike share more. They were asked to select all that apply, even if they were small barriers. For each of the selected barriers, the respondents were asked to specify if they were a "small barrier" or "big barrier." They were also given the options of selecting "not sure" or "not a barrier." The barriers and percentage of respondents selected "big barrier" is shown in Table 7-3.

Few of the items were selected as big barriers by many participants, particularly when comparing to equivalent questions on the resident survey. Target users were more likely to say that not knowing where other stations are is a big barrier (7-11\% compared to 3\% of higher-income, white users); were more likely to have concerns about paying should anything happen to the bike (4\% compared to $1 \%$ ); and to feel that checking out and returning the bikes was too complicated (4\% to $1 \%$ ). Still, these differences were much smaller than the differences between respondents in this user survey and those in the resident survey. Perhaps most notably, resident concerns about not knowing enough about how to use bike share and fears of being responsible for paying for damage or loss of the bike were each reduced dramatically for users. 
Table 7-3 Barrier to bike share

\begin{tabular}{|c|c|c|c|c|c|}
\hline \multicolumn{6}{|l|}{ lable /-3 Barrler to dike snare } \\
\hline $\begin{array}{c}\text { Bike Share Barriers - } \\
\text { Percentage indicating “big } \\
\text { barrier" }\end{array}$ & $\begin{array}{l}\text { BBSP target } \\
\text { users }\end{array}$ & $\begin{array}{l}\text { Non-BBSP } \\
\text { target users }\end{array}$ & $\begin{array}{l}\text { Higher- } \\
\text { income white } \\
\text { users }\end{array}$ & All & $\begin{array}{c}\text { Resident } \\
\text { Survey - “Big } \\
\text { Barrier" * }\end{array}$ \\
\hline $\begin{array}{l}\text { I just prefer to ride my own } \\
\text { bike }\end{array}$ & $7 \%$ & $9 \%$ & $9 \%$ & $9 \%$ & $21 \%$ \\
\hline $\begin{array}{l}\text { I can't use [BssName] with my } \\
\text { child(ren) }\end{array}$ & $9 \%$ & $4 \%$ & $6 \%$ & $6 \%$ & $11 \%$ \\
\hline $\begin{array}{l}\text { I don't know where other } \\
\text { stations are to drop off a bike }\end{array}$ & $11 \%$ & $7 \%$ & $3 \%$ & $5 \%$ & $13 \%$ \\
\hline $\begin{array}{l}\text { I worry that I'll have to pay for } \\
\text { the bike if anything happens to } \\
\text { it }\end{array}$ & $4 \%$ & $4 \%$ & $1 \%$ & $2 \%$ & $19 \%$ \\
\hline $\begin{array}{l}\text { Checking out and returning } \\
\text { [BssName] bikes is too } \\
\text { complicated }\end{array}$ & $3 \%$ & $4 \%$ & $1 \%$ & $2 \%$ & $28 \%$ \\
\hline $\begin{array}{l}\text { I worry that the [BssName] } \\
\text { bikes wouldn't adjust to fit me }\end{array}$ & $4 \%$ & $1 \%$ & $0 \%$ & $1 \%$ & $11 \%$ \\
\hline I don't have a smart phone & $1 \%$ & $0 \%$ & $0 \%$ & $0 \%$ & $9 \%$ \\
\hline $\begin{array}{l}\text { I don't want to be seen on a } \\
\text { [BssName] bike }\end{array}$ & $0 \%$ & $0 \%$ & $0 \%$ & $0 \%$ & $4 \%$ \\
\hline Responses received & 69 & 224 & 591 & 884 & $879-890$ \\
\hline
\end{tabular}

Bold indicates category value significantly greater or less than expected $(\mathrm{p}<0.05$, adj. stand. Chi-square residual).

*Note that the resident numbers presented here vary slightly from those presented in the Resident report (NITC-RR-884b). As presented here, the percentages are calculated including those who selected "does not apply" in the denominator in order to more closely match the options available in the user survey.

Respondents were also asked to tell us about the most important barrier keeping them from using bike share more. A space was provided for them to write in a response. We received written answers from 646 respondents, and coded them into thematic categories. Some responses were coded into multiple categories if they touched on multiple themes. Coded responses are shown in Table 7-4.

The most commonly mentioned barriers were the lack of convenient stations (28\%); the lack of bikes or spaces to dock a bike (22\%); and the challenge of carrying things (or children) and concerns about riding in traffic or poor bike facilities (12\% and 10\%, respectively). 
Table 7-4 Most important barrier - Open-ended responses

\begin{tabular}{|c|c|c|c|c|}
\hline Coded Response Category & $\begin{array}{l}\text { BBSP target } \\
\text { users }\end{array}$ & $\begin{array}{l}\text { Non-BBSP } \\
\text { target users }\end{array}$ & $\begin{array}{c}\text { Higher- } \\
\text { income, white } \\
\text { users }\end{array}$ & Total \\
\hline Lack of convenient stations & $33 \%$ & $25 \%$ & $29 \%$ & $28 \%$ \\
\hline Lack of bike/dock availability & $17 \%$ & $17 \%$ & $25 \%$ & $22 \%$ \\
\hline Cargo/children & $10 \%$ & $18 \%$ & $10 \%$ & $12 \%$ \\
\hline Poor bike infrastructure/traffic & $10 \%$ & $9 \%$ & $10 \%$ & $10 \%$ \\
\hline Bike quality & $10 \%$ & $6 \%$ & $8 \%$ & $7 \%$ \\
\hline Weather & $4 \%$ & $7 \%$ & $8 \%$ & $7 \%$ \\
\hline Own bike & $4 \%$ & $5 \%$ & $6 \%$ & $6 \%$ \\
\hline Time limit & $8 \%$ & $7 \%$ & $5 \%$ & $6 \%$ \\
\hline $\begin{array}{l}\text { Family and friends can't/don't use bike } \\
\text { share }\end{array}$ & $0 \%$ & $6 \%$ & $5 \%$ & $5 \%$ \\
\hline Cost & $10 \%$ & $4 \%$ & $3 \%$ & $4 \%$ \\
\hline Helmet & $2 \%$ & $4 \%$ & $5 \%$ & $4 \%$ \\
\hline Info/app & $2 \%$ & $2 \%$ & $2 \%$ & $2 \%$ \\
\hline Other & $4 \%$ & $3 \%$ & $3 \%$ & $3 \%$ \\
\hline None & $6 \%$ & $9 \%$ & $4 \%$ & $5 \%$ \\
\hline Responses received & 52 & 162 & 432 & 646 \\
\hline
\end{tabular}

Bold indicates category value significantly greater or less than expected ( $<<0.05$, adj. stand. Chi-square residual).

A sampling of the responses from BBSP target users about their most important barrier to using bike share more is included below:

- Not having a helmet available - I really don't want to constantly carry one around

- Also, I sometimes take Divvy shopping and it's difficult to carry things home safely.

- COST! Annual membership is out of my budget range. I love Divvy and would use it daily but paying day-by-day is too expensive and adds up, and buying an annual membership would take too much of a bite out of a budget that's already stretched thin.

- Would bike to and from work more if there were more bike lanes on major streets. I use it more frequently for small trips on side streets around my house.

- Unsafe roads.

- There are some routes that I don't feel safe enough biking so I will drive instead.

- Whenever I want to take the divvy either there is no bike at my source station or there are no empty docks at the destination.

- Too heavy, and dirty

- Time limit.

- the primary barriers for me are not enough stations in lower income neighborhoods and the too-short checkout time 
- I occasionally carry luggage or larger amounts of groceries with me, and there is no basket large enough for that

- I just hesitate to pay for it if it's only taking me halfway to my destination and my destination is the densely used shopping center I work in, which you'd think would have a closer stop.

\subsection{WHY OTHER PEOPLE DON'T USE BIKE SHARE}

Respondents were asked "of the people you know who do not use [the bike share system], what do you think their main reason is?" While this question requires some speculation on the part of survey respondents, it also potentially taps into their experiences and interactions with friends, family and acquaintances, as well as their own experience. We received written comments to this open-ended question from 662 people, and coded them into thematic categories. Some responses were coded into multiple categories if they touched on multiple themes. Coded responses are shown in Table 7-5.

Traffic safety fears were the most commonly mentioned reason why other people they know don't use bike share, with $43 \%$ of all respondents citing this in their responses. This is consistent with our resident survey. However, there were notable differences between the white, higherincome users, $48 \%$ of which mentioned this issue, compared to BBSP target users (23\% mentioned traffic safety) and non-BBSP target users (35\%). For these two groups of target users, other barriers or issues rose up the chain of potential reasons for acquaintances not using bike share, though traffic safety remained the most cited issue. Among BBSP target users, cost, having their own bike, not being able to ride a bike, not having enough information about bike share, and health concerns were more likely to be among the reasons mentioned for why other people they know do not use bike share. For non-BBSP target users, the cost of bike share was significantly more likely to be mentioned as a barrier for others. 
Table 7-5 Open-ended - Why others do not use bike share

\begin{tabular}{|c|c|c|c|c|}
\hline Coded Response Category & $\begin{array}{l}\text { BBSP target } \\
\text { users }\end{array}$ & $\begin{array}{c}\text { Non-BBSP target } \\
\text { users }\end{array}$ & $\begin{array}{c}\text { Higher- } \\
\text { income, white } \\
\text { users }\end{array}$ & Total \\
\hline Traffic safety/fear & $23 \%$ & $35 \%$ & $48 \%$ & $43 \%$ \\
\hline Cost & $20 \%$ & $25 \%$ & $15 \%$ & $18 \%$ \\
\hline Availability/access & $13 \%$ & $16 \%$ & $14 \%$ & $15 \%$ \\
\hline Own bike & $18 \%$ & $8 \%$ & $13 \%$ & $12 \%$ \\
\hline Can't/don’t ride & $18 \%$ & $7 \%$ & $8 \%$ & $9 \%$ \\
\hline Lack of info & $14 \%$ & $9 \%$ & $8 \%$ & $8 \%$ \\
\hline Use other transport & $7 \%$ & $6 \%$ & $7 \%$ & $7 \%$ \\
\hline Health factors/laziness & $13 \%$ & $4 \%$ & $5 \%$ & $5 \%$ \\
\hline Bike quality & $5 \%$ & $4 \%$ & $3 \%$ & $3 \%$ \\
\hline Helmet & $2 \%$ & $2 \%$ & $3 \%$ & $3 \%$ \\
\hline Not interested/not useful & $4 \%$ & $11 \%$ & $8 \%$ & $8 \%$ \\
\hline Time limit & $0 \%$ & $2 \%$ & $2 \%$ & $2 \%$ \\
\hline Effect on appearance & $0 \%$ & $5 \%$ & $2 \%$ & $3 \%$ \\
\hline Not sure & $4 \%$ & $1 \%$ & $4 \%$ & $3 \%$ \\
\hline Other & $7 \%$ & $3 \%$ & $1 \%$ & $2 \%$ \\
\hline Responses received & 56 & 170 & 436 & 662 \\
\hline
\end{tabular}

Bold indicates category value significantly greater or less than expected $(\mathrm{p}<0.05$, adj. stand. Chi-square residual).

A sampling of the responses from BBSP target users for why other people they know don't use bike share is provided below:

- It's dangerous, lack of protected bike lanes in Chicago. Painted bike lanes on existing roads do not count as safe.

- Prohibitively expensive.

- The cost and also they have their own bikes.

- They do not know about the discounted program

- I think for some they don't think they'd use it enough, for some they're not comfortable riding an unfamiliar bike without a helmet, and for some it's a cost issue.

- Just don't ride bikes. 


\subsection{CONCLUSIONS}

The findings in this report on bike share users provide a complementary examination, along with earlier companion reports on current efforts by bike share operations (NITC-RR-884a) and views of community residents (NITC-RR-884b), into the current state and potential impact of bike share on lower-income individuals and people of color. Specifically, this report seeks to provide more information about lower-income people and people of color who engage in bike share, including why they choose to become members, how they use the system and how they benefit. The report looks at current and past bike share members, along with those who were involved in some type of equity-based outreach program.

The findings draw from a survey intended to reach lower-income people and/or people of color known to have engaged in bike share, either through membership or participating in events such as organized rides, in the same three cities studied in the resident report (NITC-RR-884b) - New York (Brooklyn), Chicago and Philadelphia. With some variation by city, the survey was distributed to people who lived in or adjacent to neighborhoods targeted by equity-focused outreach efforts and had joined bike share, as well as people system-wide who participated in equity-focused programs, including discounts and events.

Respondents were divided into three groups for analysis. Two groups consisted of users targeted for the equity-focused outreach efforts - lower-income individuals and people of color. One of these groups included those who took advantage of equity-focused discounts or related programs ("BBSP target users"); the other group included those who did not partake in such focused discounts or programs ("non-BBSP target users"). The third analysis group consisted of higherincome, white users. Due to a larger sample and higher response rate, $80 \%$ of those who could be placed into one of these three groups were from Brooklyn. However, a large majority of these Brooklyn respondents were higher income and white. A majority (64\%) of the 70 BBSP target users were from Chicago, 21\% were from Brooklyn and 14\% from Philadelphia. About half of BBSP target users were lower income and white, while the remainder were people of color, either lower or higher income. Due to the low number of BBSP target users, and the fact that the majority of this group came from one city, the findings should be interpreted with some caution. In some cases, further research may be needed to be confident in extrapolating findings to other locations.

\subsection{SOURCES OF INFORMATION DIFFER FOR BBSP TARGET USERS}

One barrier to bike share use is learning about bike share and how to use the system. For all users, the main sources of information were from the internet, from friends or family, and from bike share stations. Within those three main sources of information, BBSP target users were much less likely to have gotten information or first learned about bike share from their friends or family. This disparity persisted even once participants had joined the system; BBSP target users were more likely to say they had no friends, family or close acquaintances who were bike share 
members. BBSP target users were also less likely to report using bike share in another city. Several other sources were more likely to be listed by BBSP target users than other respondents, including talking to someone at an event, information at work or school, and a newspaper.

Taken together, these sources of information and introductory bike share experiences suggest that people in the BBSP target user group were less likely to have exposure to bike share through their existing networks (e.g., friends and family) or through their personal experiences (including using bike share in other places). They were more likely to have exposure to bike share through some of the intervention methods used in the outreach efforts, such as finding out about bike share at events or finding out about available discounts for them. This is partly due to how the group is defined, but also indicates that these interventions may be helping to overcome the lack of social networks as a source of information. This is consistent with findings from the resident report that more intensive outreach was more likely to be associated with intentions to use however, reaching a large number of people with the outreach is challenging. A goal should be to close the gap in social network exposure over time, so that lower-income individuals and people of color are just as likely to know people who use bike share and have a general awareness of the bike share program, how it works and the potential benefits of use. Resident survey findings were encouraging in that a high share of lower-income people of color intended to learn more about and try bike share in the near future.

\subsection{COST CONSIDERATIONS, INCLUDING MEMBERSHIP DISCOUNTS, ARE IMPORTANT}

Throughout the survey, target users were more concerned about and motivated by cost issues, particularly the BBSP target users. This is not surprising because of how income and participation in discount programs were used to define the groups. BBSP target users, in selfreported reasons for why they joined, were most likely to state either the cost savings or discounted membership, while other users were more likely to state the convenience of using bike share. This indicates that the discount programs are likely reaching people who would not otherwise join bike share. Moreover, about two-thirds of BBSP target users stated that they were "very likely" to renew their membership (the same as for the other groups) and they rode as frequently as other users. This is another indication that the discount programs are effective.

Target users were more likely to pay monthly for bike share. However, in cities that offer a monthly and annual payment option, it could mean that lower-income people and people of color will be paying a higher effective rate than higher-income, white members. Other research has found that lower-income people, when given an option, often opt for more frequent payments that may over time cost more versus one-time payments, usually due to income constraints and lack of savings (Blumenberg and Agrawal 2014). 


\subsection{ALL USERS RIDE ABOUT THE SAME AMOUNT, BUT FOR SLIGHTLY DIFFERENT PURPOSES}

All respondents were generally frequent users, with over half indicating that they make 11 or more bike share trips per month in good weather and a third reporting making 20 or more trips per month. This suggests that once target users become members, perhaps with the help of a discount membership, they may use bike share as often as white, higher-income users. This is encouraging, as it suggests that if membership barriers can be overcome, target users are just as likely to use the system.

Across all analysis groups, commuting and transit access were the most common uses of bike share. BBSP target users were more likely to ride just for fun or for exercise. This is consistent with the resident survey which found that exercise and fun were leading reasons for why lowerincome people of color might try bike share. Though not a large share of bike share trips, BBSP target users were also more likely to use bike share for school, daycare or religious-related trips, as well as for trips related to looking for work or job/skill training. These findings indicate that, for at least some lower-income users, bike share may help them access better economic opportunities.

\subsection{USERS ARE BENEFITING FROM BIKE SHARE IN MANY WAYS}

Overall, exercise, time savings and convenience/flexibility were the most commonly stated benefits of bike share. Interestingly, BBSP target users were more likely than any other group to mention the time savings afforded by bike share, with $41 \%$ volunteering this as a reason bike share is important to them. However, when asked about why they initially joined, less than half that share of BBSP target users noted the relative speed of bike share as a draw. This gap between expectations and experiences of program participants suggests a potential role for better marketing around potential time savings for that group. Most of the users' bike share trips were substituting for transit or walking trips, both modes that can be slower than bicycling in many circumstances. BBSP target users also had access to fewer alternatives, with significantly smaller shares reporting using ride-hailing services (e.g. Taxi, Uber, Lyft) or having either a working bicycle of their own or a car share membership.

Respondents also indicated that bike share was saving them money. Among all respondents, about half indicated that they were spending less on transportation overall. BBSP target users reported saving the most, with a quarter of respondents in that group reporting saving \$21 or more per week, and a majority saving more than \$6 per week. Most of those receiving discounts were realizing savings that exceeded the discount amount, an encouraging sign for the value of the program and for retaining those members even if discounts end. In addition, a small share (16\%) of the BBSP target users indicated that they were spending less on health care costs because of bike share - more than for the other two groups. This may be linked to the high share of these respondents indicating that they are getting more exercise because of bike share, and a lower share (compared to white, higher-income users) indicating that they were in excellent health. 


\subsection{ARE THERE BARRIERS TO THESE USERS USING BIKE SHARE MORE?}

Respondents to this survey are using bike share frequently, which means they have overcome some of the barriers to using bike share that we found in the resident survey, where few respondents had used bike share. In particular, traffic safety was cited less often as a big barrier in the user survey than in the resident survey. Given that the samples were similar geographically, this may reveal differences in attitudes and confidence levels rather than the environment. It is likely that many of these users were more comfortable bicycling in traffic to begin with, though it is also possible that some users became more comfortable through their use of bike share. When we asked respondents to tell us their views on why other people they know don't use bike share, concerns about traffic safety and cost rose to the top of the list.

The top barrier to using bike share more in the user survey was that of distances being too far to bike, at rates similar to the resident survey. As in the resident survey, white, higher-income respondents were less likely to list this as a big barrier than other respondents. Further research is needed to understand whether lower-income people and people of color tend to have destinations that are farther away, or instead are simply less willing to bicycle increasing distances compared to higher-income whites.

For current users, regardless of user group, more stations, bikes and docks were viewed as the things that would make them most likely to use bike share more, and a lack thereof acting as a barrier to use. Better quality bike infrastructure/routes were both noted as things that would make them ride more and a lack of them as key barriers.

A majority of the BBSP target users, more so than the other groups, indicated that having longer time limits on bike share rides would encourage them to use it more. This may be linked to both using bike share for exercise and concerns about having to pay for longer trips. The target users were also more likely to increase their use if the fees for longer trips were lower. These findings indicate that changes to pricing structures may encourage more use among lower-income people and people of color.

\subsection{POLICY SUGGESTIONS AND FUTURE RESEARCH DIRECTIONS}

The findings from this survey suggest several policy approaches, and point to several areas where further study is required.

The differences in access to information about bike share point to importance of direct outreach to target populations. Since BBSP target users are less likely to have friends and family who have used bike share or to have used bike share in other cities, successful programs will have to serve as the first point of contact to reach these users. Discount programs appear to be an important part of reaching these users, making the initial use of bike share more approachable and appealing from a cost perspective. Once participating, BBSP target users appear to view bike share as providing a personal cost savings in excess of the cost of the membership price and/or 
subsidy. However, long-term retention (and price points that will make membership renewal appealing) requires further study.

Further consideration of potential for recreation and exercise use of bike share among target populations appears to be warranted. Related to this, time limits and excess time penalties should be further examined as potential barriers to greater use among target populations. Additionally, more in-depth examination is needed regarding low frequency but potentially high value bike share trips such as those related to education, job training, and job seeking.

It is encouraging that many of the key barriers and motivating factors to bike share use noted by target respondents (e.g. discounts, personalized outreach, extra charges) were also key aspects of BBSP programs in each city. Equity-focused programs should continue to find ways to get information to target groups and to make membership appealing and affordable.

Finally, this study is limited by its focus on select neighborhoods in three cities. A broader survey of target population bike share users nationally would be helpful to better understand transferability of these initial results and perhaps reveal additional issues relevant in different settings. As equity-focused programs expand to other systems, continuing research will be needed to evaluate specific approaches to reaching diverse target populations. 


\subsection{REFERENCES}

Bachand-Marleau, J., B. Lee, and A. El-Geneidy (2012). Better understanding of factors influencing likelihood of using shared bicycle systems and frequency of use. Transportation Research Record: Journal of the Transportation Research Board 2314: 66-71. Nov. 2011. Web. 26 Feb. 2016.

Blumenberg, E. and A.W. Agrawal. Getting around when you're just getting by: Transportation survival strategies of the poor. Journal of Poverty, 18:4, 355-378.

Brown, C.T., and J. Sinclair (2017). Removing Barriers to Bicycle Use in Black and Hispanic Communities. Presented at the Transportation Research Board Annual Meeting, January 10, 2017.

Buck, D., R. Buehler, P. Happ, B. Rawls, P. Chung, and N. Borecki. Are bikeshare users different from regular cyclists? A first look at short-term users, annual members, and area cyclists in the Washington, D.C. region. Transportation Research Record: Journal of the Transportation Research Board 2387 (2013): 112-119.

Community Cycling Center (2012). Understanding Barriers to Bicycling Project. Final Report. Accessed at http://www.communitycyclingcenter.org/wpcontent/uploads/2012/07/Understanding-Barriers-Final-Report.pdf.

Daddio, D. W. Maximizing Bicycle Sharing: An Empirical Analysis of Capital Bikeshare Usage. Master's Project. University of North Carolina at Chapel Hill, 2012.

Dixon, I., J. Tanzman, and M.L. Hoffman. (2015). Diverse Bicyclists, Diverse Needs: Cycles for Change Community Conversations. Report for Cycles for Change.

Federal Deposit Insurance Corporation (2015). FDIC National Survey of Unbanked and Underbanked Households. n.p., 2015. Web. 07 Apr. 2017. Feb. 2016. Accessible at https://www.fdic.gov/householdsurvey .

Fishman, E., Washington, S., \& Haworth, N. (2014). Bike share’s impact on car use: Evidence from the United States, Great Britain, and Australia. Transportation Research Part D: Transport and Environment, 31(2), 13-20. http://doi.org/10.1016/j.trd.2014.05.013

Fuller, D., Gauvin, L., Kestens, Y., Daniel, M., Fournier, M., Morency, P., and Drouin, L. (2011). Use of a new public bicycle share program in Montreal, Canada. American Journal of Preventive Medicine, 41(1), 80-83.

Hoe, N. and Kaloustian, T. (2014). Bike Sharing in Low-Income Communities: An Analysis of Focus Groups Findings. Temple University Institute for Survey Research. Accessible at http://b.3cdn.net/bikes/fc16c31cbff25139a1_3cm6bfs04.pdf.

Hoe, Nina. (2015a). Bike Sharing in Low-Income Communities: Results from a Spring 2015 Baseline Survey. Temple University Institute for Survey Research Report. July 2015. 
Hoe, Nina. (2015b). Bike Sharing in Low-Income Communities: Perceptions and Knowledge April — October 2015. Temple University Institute for Survey Research Report. December 2015.

Howland, Steven, Nathan McNeil, Joseph Broach, Kenneth Rankins, John MacArthur, and Jennifer Dill. Breaking Barriers to Bike Share: Insights on Equity from a Survey of Bike Share System Owners and Operators. NITC-RR-884a. Portland, OR: Transportation Research and Education Center (TREC), 2017.

Kodransky, M. and Lewenstein, G. (2014). Connecting Low-Income People to Opportunity with Shared Mobility. Final Report and Case Studies. Institute for Transportation and Development Policy.

McNeil, Nathan, Jennifer Dill, John MacArthur, Joseph Broach, Steven Howland. Breaking Barriers to Bike Share: Insights from Residents of Traditionally Underserved Neighborhoods. NITCN-RR-884b. Portland, OR: Transportation Research and Education Center (TREC), 2017.

National Association of Realtors (NAR) and Portland State University (PSU) (2015). Community and Transportation Preferences Survey, 2015. Accessible at http://nitc.trec.pdx.edu/research/project/668/.

Ogilvie, F., and Goodman, A. (2012). Inequalities in usage of a public bicycle sharing scheme: socio-demographic predictors of uptake and usage of the London (UK) cycle hire scheme. Preventive Medicine, 55(1), 40-45.

Perrin, A., and Duggan, M. (2015). Americans’ Internet Access: 2000-2015. Pew Research Center, June.

Pew Research Center. (2015). The Smartphone Difference. April. http://www.pewinternet.org/2015/04/01/us-smartphone-use-in-2015/

Rixey, R. A. (2013). Station-level forecasting of bikesharing ridership. Transportation Research Record: Journal of the Transportation Research Board, 2387(1), 46-55.

Shaheen, S. A., Martin, E. W., \& Chan, N. D. (2012). Public Bikesharing in North America: Early Operator and User Understanding. Mineta Transportation Institute Report 11-19. Retrieved from http://scholarworks.sjsu.edu/mti_publications/73

Shaheen, S., Martin, E., Chan, N.D., Cohen, A.P., and Pogodzinki, M. (2014). Public Bikesharing in North America During a Period of Rapid Expansion: Understanding Business Models, Industry Trends and User Impacts. San Jose, CA: Mineta Transportation Institute.

Shaheen, S., M. J. Christensen, and I. Viegas de Lima. (2015). Bay Area Bike Share Casual Users Survey Report: A comparative analysis of existing and potential bikesharing users. Report to Transportation Sustainability Research Center, University of California, Berkeley, 2015. 
Sharpe, D. (2015). Your Chi-Square Test Is Statistically Significant: Now What? Practical Assessment, Research \& Evaluation, 20(8), 1-10.

Smith, C. S., J.S. Oh, and C. Lei. Exploring the Equity Dimensions of US Bicycle Sharing Systems. Report TRCLC 14-01. Transportation Research Center for Livable Communities. 2015.

Stewart, S.K., Johnson, D.C., and Smith, W.P. (2013). Bringing bike share to a low-income community: Lessons learned through community engagement, Minneapolis, Minnesota, 2011. Preventing Chronic Disease, DOI:10.5888/pcd10.120274.

Ursaki, J. and L. Aultman-Hall. (2016). Quantifying the equity of bikeshare access in U.S. cities. Transportation Research Board Annual Meeting, 2016. Paper \# 16-0426.

Virginia Tech. (2012). Capital Bikeshare study: A closer look at casual users and operation. Arlington: Virginia Tech. 


\subsection{APPENDIX}

Sample Survey from Chicago / Divvy Deployment 


\section{Neighborhood Transportation Survey 슷}

The Transportation Research and Education Center (TREC) at Portland State University (PSU) is conducting a survey of people who either use bike share, or have received information about bike share (such as through talking to someone at an outreach event, signing up to receive information about bike share, etc.). The survey is being conducted in several cities around the country. Your feedback will help us learn about if and how you use bike share, what is important to you and how services like this can better serve your community.

The survey should take 15-25 minutes, and you must be 18 or older to participate. You do not have to participate, and you can skip any questions you do not want to answer. Your responses will be completely confidential. It will not be possible to tell who said what in any reports. We do not anticipate any risk to you in answering the survey.

If you have any questions about the study, please contact the research team at streets@pdx.edu or 503-725-2875. This research is sponsored by the U.S. Department of Transportation through the National Institute for Transportation and Communities, and by the Better Bike Share Partnership.

This research can only be a success with the generous help of people like you. We hope you will enjoy answering our questions. We look forward to receiving your responses.

All people who return their survey to us by December 9th will be entered into a drawing for a gift card to Amazon.com (in the amount of \$250). Further, the first 20 people who respond will receive two single-ride CTA tickets.

This study has been reviewed and approved by PSU's Human Subjects Research Review Committee. If you have any questions about your rights as a participant in this study, you may contact the PSU Office of Research Integrity, 1600 SW 4th Ave., Market Center Building, Ste. 620, Portland, OR 97201; phone (503) 725-2227 or 1 (877) 480-4400.

If you agree to participate in the study by taking our survey, please press the ">" button to start the survey.

\section{About your travel and neighborhood}

In the past week, how did you get around Chicago?

Drove a personal car

Got a ride from a friend or family member

Taxi / Uber / Lyft

Car Share (Zipcar, Getaround, etc.)

Public transit (bus, rail, etc.)

Walking

Bicycling - bike share / Divvy

Bicycling - personal bike

Other

$\begin{array}{ccc}\text { No Trips } & \text { Some Trips } & \text { Most Trips } \\ 0 & 0 & 0 \\ 0 & 0 & 0 \\ 0 & 0 & 0 \\ 0 & 0 & 0 \\ 0 & 0 & 0 \\ 0 & 0 & 0 \\ 0 & 0 & 0 \\ 0 & 0 & 0 \\ 0 & 0 & 0\end{array}$

What is your home zipcode? 
Do you agree or disagree with the following statements about your neighborhood?

\begin{tabular}{|c|c|c|c|c|c|}
\hline & $\begin{array}{l}\text { Strongly } \\
\text { Disagree }\end{array}$ & Disagree & Agree & $\begin{array}{c}\text { Strongly } \\
\text { Agree }\end{array}$ & $\begin{array}{c}\text { No } \\
\text { Opinion }\end{array}$ \\
\hline $\begin{array}{l}\text { I am satisfied with my options for getting where I } \\
\text { need to go }\end{array}$ & 0 & 0 & 0 & 0 & 0 \\
\hline $\begin{array}{l}\text { I usually know about community and social events } \\
\text { in my neighborhood }\end{array}$ & 0 & 0 & 0 & 0 & 0 \\
\hline $\begin{array}{l}\text { I know about services provided by community or } \\
\text { faith-based organizations in my neighborhood }\end{array}$ & 0 & 0 & 0 & 0 & 0 \\
\hline $\begin{array}{l}\text { Recent changes make my neighborhood more } \\
\text { appealing to me }\end{array}$ & 0 & 0 & 0 & 0 & O \\
\hline $\begin{array}{l}\text { I may have to leave my neighborhood because it is } \\
\text { getting too expensive }\end{array}$ & 0 & 0 & 0 & 0 & 0 \\
\hline $\begin{array}{l}\text { I have provided input on decisions affecting my } \\
\text { neighborhood }\end{array}$ & 0 & 0 & 0 & 0 & 0 \\
\hline $\begin{array}{l}\text { Concerns of people like me are considered in } \\
\text { decisions affecting my neighborhood }\end{array}$ & 0 & O & O & O & O \\
\hline $\begin{array}{l}\text { My city government does a good job or serving } \\
\text { people like me }\end{array}$ & 0 & 0 & 0 & 0 & 0 \\
\hline $\begin{array}{l}\text { My options for getting around have gotten better in } \\
\text { the past } 12 \text { months }\end{array}$ & O & O & O & O & O \\
\hline $\begin{array}{l}\text { The public transit agency does a good job serving } \\
\text { people like me }\end{array}$ & O & 0 & 0 & O & O \\
\hline
\end{tabular}

\section{Questions about Divvy - Chicago's bike share system}

Divvy is Chicago's public bike share system. People can check out a bike (like the one pictured below) from any Divvy station, ride it wherever they want, and return it to any other station.

How much would you say you know about Divvy?

O Know nothing about it

O Know very little about it

O Know some things about it

O Know quite a bit about it

O Know a lot about it 


\section{Sample User Survey - Chicago}

Whether or not you have used bike share, please indicate if you agree or disagree with each statement:

\begin{tabular}{l|cccc} 
& $\begin{array}{c}\text { Strongly } \\
\text { Disagree }\end{array}$ & Disagree & Agree & $\begin{array}{c}\text { Strongly } \\
\text { Agree }\end{array}$ \\
Opinion
\end{tabular}

Are you a Divvy member?

O Yes, current member

O Was a member in the past

O No, never have been a member 


\section{Sample User Survey - Chicago}

Where had you gotten information about Divvy BEFORE you joined?

Check all that apply. IF none apply, check the "None of these" box

$\square$ At a bike share station/ kiosk

$\square$ Talked to someone at an event

$\square$ Got something in the mail

$\square$ Ads on buses or bus shelters

$\square$ Talked to someone from Go Bronzeville

$\square$ On a billboard

$\square$ Information at work or school

$\square$ Radio

$\square$ Television

$\square$ Newspaper

$\square$ On the internet

$\square$ Friends or Family

$\square$ At a community center of faith-based organization

口 "Go Kit" from Go Bronzeville

$\square$ Other

$\square$ None of these - I had not gotten any information about Divvy before I joined

$\square$ None of these - I have not gotten any information about Divvy

Of the ways that you've gotten information about Divvy, how important was the information from each of the following sources when deciding to become a bike share member?

\begin{tabular}{|c|c|c|c|c|c|}
\hline & $\begin{array}{l}\text { Not } \\
\text { important }\end{array}$ & $\begin{array}{l}\text { Somewhat } \\
\text { Important }\end{array}$ & Important & $\begin{array}{c}\text { Very } \\
\text { Important }\end{array}$ & $\begin{array}{l}\text { Not } \\
\text { Sure }\end{array}$ \\
\hline At a bike share station/ kiosk & O & O & 0 & O & O \\
\hline Talked to someone at an event & O & O & O & O & O \\
\hline Got something in the mail & O & O & O & O & 0 \\
\hline Ads on buses or bus shelters & O & O & O & O & O \\
\hline $\begin{array}{l}\text { Talked to someone from Go } \\
\text { Bronzeville }\end{array}$ & O & O & O & O & ○ \\
\hline On a billboard & O & O & O & O & 0 \\
\hline Information at work or school & O & O & O & O & O \\
\hline Radio & O & O & O & O & 0 \\
\hline Television & O & O & O & O & 0 \\
\hline Newspaper & O & O & O & O & 0 \\
\hline On the internet & O & O & 0 & O & 0 \\
\hline Friends or Family & O & O & O & O & 0 \\
\hline $\begin{array}{l}\text { At a community center of faith-based } \\
\text { organization }\end{array}$ & O & O & O & O & O \\
\hline "Go Kit" from Go Bronzeville & O & O & O & O & 0 \\
\hline Other & O & O & O & O & O \\
\hline $\begin{array}{l}\text { None of these - I had not gotten any } \\
\text { information about Divvy before I } \\
\text { joined }\end{array}$ & O & O & O & O & 0 \\
\hline $\begin{array}{l}\text { None of these - I have not gotten any } \\
\text { information about Divvy }\end{array}$ & O & O & O & O & O \\
\hline
\end{tabular}


Please explain specifically where and how you first learned about Divvy: [open text response]

Had you done any of the following BEFORE you joined Divvy?

\section{Check all that apply. IF none apply, check the "NONE APPLY" box}

$\square$ Noticed a Divvy station/ kiosk near your home

$\square$ Rode a Divvy bike that you paid to use

$\square$ Rode a Divvy bike at an event

$\square$ Rode a Divvy bike on a "Free Ride Weekend"

$\square$ Rode a Divvy bike using a free coupon

$\square$ Rode a Divvy bike that someone else checked out for you

$\square$ Had friends or family that used Divvy

$\square$ Heard about an organized Divvy ride that you could join

$\square$ Went on an organized bike ride where you learned about Divvy

$\square$ Followed Divvy on Instagram, Twitter, Facebook, or Email

$\square$ Attended a special event related to Divvy

$\square$ Found out you qualified for a discounted membership or pass

$\square$ Talked to someone who worked for Divvy

$\square$ Used a bike share bike from another system (not Divvy)

$\square$ NONE APPLY - I did not do any of these before joining Divvy

$\square$ NONE APPLY - I have not done any of these

Of the previous items that you have done in relation to Divvy, how important were each of the following things when deciding to become a bike share member or passholder?

\begin{tabular}{|c|c|c|c|c|c|}
\hline & $\begin{array}{l}\text { Not } \\
\text { important }\end{array}$ & $\begin{array}{l}\text { Somewhat } \\
\text { Important }\end{array}$ & Important & $\begin{array}{l}\text { Very } \\
\text { Important }\end{array}$ & $\begin{array}{l}\text { Not } \\
\text { Sure }\end{array}$ \\
\hline $\begin{array}{l}\text { Noticed a Divvy station/ kiosk near your } \\
\text { home }\end{array}$ & O & O & O & O & O \\
\hline Rode a Divvy bike that you paid to use & O & O & O & O & O \\
\hline Rode a Divvy bike at an event & O & O & O & O & O \\
\hline Rode a Divvy bike on a "Free Ride Weekend" & O & O & O & O & O \\
\hline Rode a Divvy bike using a free coupon & O & O & O & O & O \\
\hline $\begin{array}{l}\text { Rode a Divvy bike that someone else } \\
\text { checked out for you }\end{array}$ & O & O & O & O & O \\
\hline Had friends or family that used Divvy & O & O & O & O & O \\
\hline $\begin{array}{l}\text { Heard about an organized Divvy ride that } \\
\text { you could join }\end{array}$ & O & O & O & O & O \\
\hline $\begin{array}{l}\text { Went on an organized bike ride where you } \\
\text { learned about Divvy }\end{array}$ & O & O & O & O & O \\
\hline $\begin{array}{l}\text { Followed Divvy on Instagram, Twitter, } \\
\text { Facebook, or Email }\end{array}$ & O & O & O & 0 & O \\
\hline Attended a special event related to Divvy & O & O & O & O & O \\
\hline $\begin{array}{l}\text { Found out you qualified for a discounted } \\
\text { membership or pass }\end{array}$ & O & O & O & O & O \\
\hline Talked to someone who worked for Divvy & O & O & 0 & O & O \\
\hline $\begin{array}{l}\text { Used a bike share bike from another system } \\
\text { (not Divvy) }\end{array}$ & O & O & O & 0 & O \\
\hline $\begin{array}{l}\text { NONE APPLY - I did not do any of these } \\
\text { before joining Divvy }\end{array}$ & O & O & O & O & O \\
\hline NONE APPLY - I have not done any of these & O & O & 0 & O & O \\
\hline
\end{tabular}




\section{Sample User Survey - Chicago}

In the next 6 months, how likely are you to...

\begin{tabular}{|c|c|c|c|c|}
\hline & $\begin{array}{l}\text { Not at all } \\
\text { likely }\end{array}$ & $\begin{array}{l}\text { Not } \\
\text { likely }\end{array}$ & $\begin{array}{l}\text { Somewhat } \\
\text { likely }\end{array}$ & $\begin{array}{l}\text { Very } \\
\text { likely }\end{array}$ \\
\hline Seek more information about using Divvy & O & O & O & O \\
\hline Tell someone you know about Divvy & O & O & O & O \\
\hline Ride a Divvy bike? & 0 & 0 & 0 & 0 \\
\hline
\end{tabular}

Would the following changes make you more likely to use Divvy?

\begin{tabular}{l|cccc} 
& $\begin{array}{c}\text { No more } \\
\text { likely }\end{array}$ & $\begin{array}{c}\text { Somewhat } \\
\text { more } \\
\text { likely }\end{array}$ & $\begin{array}{c}\text { Much } \\
\text { more } \\
\text { likely }\end{array}$ & $\begin{array}{c}\text { Does } \\
\text { not } \\
\text { apply }\end{array}$ \\
\hline Access to free or low cost helmets and other gear & 0 & 0 & 0 & 0 \\
Organized rides for people like me & 0 & 0 & 0 & 0 \\
If more of my friends or family could use Divvy with me & 0 & 0 & 0 & 0 \\
Help finding safe ways to get where I need to go & 0 & 0 & 0 & 0 \\
More Divvy stations close together & 0 & 0 & 0 & 0 \\
More Divvy stations where I want to go & 0 & 0 & 0 & 0 \\
Longer time limits for checking out bikes & 0 & 0 & 0 & 0 \\
Lower fees for keeping a bike out too long & 0 & 0 & 0 & 0 \\
More docks or bikes at existing stations & 0 & 0 & 0 & 0 \\
Better bike routes (e.g. bike lanes or trails) that & 0 & 0 & 0 & 0 \\
connect Divvy stations & & & &
\end{tabular}

Describe the one thing that would make you more likely to use Divvy: [open text response]

\section{About your Divvy use}

How many of your family / friends / close acquaintances have Divvy memberships?

O 0 / zero

O 1

O $2-3$

O 4 or more

How have you paid for Divvy Bike Share?

\begin{tabular}{l|ccc} 
& Currently & Not currently, but in the past & Never \\
\hline As an annual member, paid up front & 0 & 0 & 0 \\
As an annual member, paid monthly & 0 & 0 & 0 \\
With a day pass & 0 & 0 & 0 \\
Used a friend's bike / membership & 0 & 0 & 0
\end{tabular}

Please describe why you chose to try bike share or become a member. [open text response]

Describe how Divvy is important to you. [open text response] 


\section{Sample User Survey - Chicago}

For some people, bike share can help overcome barriers to riding a bicycle. To what degree did bike share help you with these potential barriers?

n't have a bike or related gear (such as helmet / lock / lights)

It is too expensive to buy a bike or related gear I don't have a safe place to store a bike at home There might not be a safe place to leave a bike at the places I go

Does not apply - was not a barrier for me
Bike share helped a little
Bike share helped a lot

When did you first purchase a Divvy membership? [Year, Month]

When the weather was nice, about how often did you ride a bicycle...

\begin{tabular}{l|cccccc} 
& $\begin{array}{c}\text { Less than } 1 \\
\text { day per } \\
\text { month }\end{array}$ & $\begin{array}{c}1-3 \text { days } \\
\text { per } \\
\text { month }\end{array}$ & $\begin{array}{c}1-2 \text { days } \\
\text { per } \\
\text { week }\end{array}$ & $\begin{array}{c}3-5 \text { days } \\
\text { per } \\
\text { week }\end{array}$ & $\begin{array}{c}6 \text { or more } \\
\text { days per } \\
\text { week }\end{array}$ & $\begin{array}{c}\text { Does } \\
\text { not } \\
\text { apply }\end{array}$ \\
\hline In the year before you joined Divvy? & 0 & 0 & 0 & 0 & 0 & 0 \\
Since joining Divvy? & 0 & 0 & 0 & 0 & 0 & 0
\end{tabular}

What percent of your total bike trips are made using Divvy bikes? [0-100\%]

Have you used (or do you plan to use) cash for paying for Divvy membership or fees?

$$
\begin{aligned}
& O \text { Yes } \\
& \text { O No }
\end{aligned}
$$

How do you use (or plan to use) CASH to purchase Divvy memberships or passes? Check all that apply.

$\square$ Never used cash

$\square$ Used cash when I first joined

$\square$ Used cash to renew my membership

$\square$ Used cash to pay for usage fees

$\square$ Plan to use cash to renew or to purchase a membership in the future

Why did you choose to pay with the cash option? [open text response]

\begin{tabular}{|c|c|c|c|c|c|}
\hline & $\begin{array}{l}\text { Very } \\
\text { difficult }\end{array}$ & Difficult & $\begin{array}{l}\text { Neither easy } \\
\text { nor difficult }\end{array}$ & Easy & $\begin{array}{l}\text { Very } \\
\text { Easy }\end{array}$ \\
\hline $\begin{array}{l}\text { Getting to locations to purchase a cash } \\
\text { membership }\end{array}$ & O & O & O & O & O \\
\hline Completing signup and making payment & O & O & O & O & O \\
\hline $\begin{array}{l}\text { Overall process of getting and using a cash } \\
\text { membership }\end{array}$ & O & O & O & O & O \\
\hline Other & 0 & O & O & O & O \\
\hline
\end{tabular}

How easy were the following ways of getting and using a cash membership?

Is there anything you would do to improve the cash payment process? [open text response] The following questions ask about your past memberships or passes.

How long has it been since your membership was active?

Why are you no longer a Divvy member? Please briefly describe. [open text response] 


\section{Sample User Survey - Chicago}

What might cause you to rejoin? Check all that apply.

$\square$ Weather only - I'm planning to re-purchase my pass in the spring

$\square$ A discount

$\square$ More stations where I need them

$\square$ If there were more safe places to ride

$\square$ Nothing, I'm done

$\square$ Other:

Do you have a discounted Divvy membership?

O No, I pay the full price (currently, $\$ 99 /$ year or $\$ 9.95 /$ month)

O Yes

O Don't Know / Not Sure

What type of discounted membership do you have?

O Discounted membership through my employer

O Discounted membership through my university / school

O Divvy for Everyone - $\$ 5$ for one year

O Divvy for Everyone - renewed for $\$ 50 /$ year

O Divvy for Everyone - renewed for $\$ 5 /$ month

O Other:

O Don't Kñw / Not Sure

IF you signed up for Divvy at a LISC Financial Opportunity Center, can you tell us which one?

(Click here for a map of LISC sites if needed)

O I DID NOT sign up at a LISC Financial Opportunity Center

O J ane Addams Resource Corporation (4432 N. Ravenswood Ave)

O Center for Changing Lives (1955 N. St Louis Ave)

O Central States SER (10 S. Kedzie)

O Central States SER (3948 W. 26th St)

O The Cara Program, Quad Communities Center for Working Families (4655 S. King Dr)

O Metropolitan Families Services (747 W. 63rd St)

How likely are you to renew your current membership?

O Very Likely

O Likely

O Undecided

O Unlikely

O Very Unlikely

Why are you undecided or unlikely to renew your current membership or pass? Please briefly describe.

[open text response

Of the people you know who do not use Divvy, what do you think their main reason is? [open text response]

Questions about your use of Divvy - Chicago's bike share system 


\section{Sample User Survey - Chicago}

Since becoming $n$ member, have you used Divvy...?

O Less than expected

O As much as expected

More than expected

O Don't know / Not sure

During months when the weather is nice, about how many Divvy trips do you make in a typical MONTH? Count each point-to-point trip as one trip (E.g. a trip from home to work, and then from work back to home would be 2 trips)
O No trips
O 1-2 trips
O 3-5 trips
O 6-10 trips
O 11-19 trips
O 20 or more trips

Do you usually take bike share trips on weekdays, weekends, or a mix?
O Mostly weekdays
O Mostly weekends
O Even mix between weekdays and weekends
O Not sure

During months when the weather is nice, how often do you use Divvy for each of the following types of trips in a typical MONTH?

\begin{tabular}{|c|c|c|c|c|c|c|}
\hline & Never & $\begin{array}{l}\text { Less } \\
\text { than } 1 \\
\text { time } \\
\text { per } \\
\text { month }\end{array}$ & $\begin{array}{c}1-3 \\
\text { days } \\
\text { per } \\
\text { month }\end{array}$ & $\begin{array}{c}1-2 \\
\text { days } \\
\text { per } \\
\text { week }\end{array}$ & $\begin{array}{c}\text { 3-5 } \\
\text { days } \\
\text { per } \\
\text { week }\end{array}$ & $\begin{array}{c}6 \text { or } \\
\text { more } \\
\text { times } \\
\text { per } \\
\text { week }\end{array}$ \\
\hline J ust out for a ride / exercise & O & O & O & O & O & O \\
\hline To / From Public Transit & O & O & 0 & O & O & O \\
\hline Work / Commute & O & O & O & O & O & O \\
\hline School / Daycare / Religious & O & O & O & O & O & O \\
\hline Medical / Dental & O & O & O & O & O & O \\
\hline Shopping / Errands & O & O & O & O & O & O \\
\hline Social / Recreational & O & O & O & O & O & O \\
\hline Family personal business / obligations & O & O & O & 0 & 0 & 0 \\
\hline Meals & 0 & 0 & 0 & 0 & 0 & 0 \\
\hline $\begin{array}{l}\text { Look for work / Get to a job interview / } \\
\text { Trainings }\end{array}$ & 0 & 0 & 0 & 0 & 0 & 0 \\
\hline Other & 0 & 0 & 0 & 0 & 0 & 0 \\
\hline
\end{tabular}

Thinking about your Divvy trips, how would you typically have made those trips if bike share were not available? Indicate what percentage of your bike share trips are replacing trips that would have otherwise been taken by each alternative.

Public transit (bus, trolley, subway, regional rail) :

Personal bicycle:

Drive in a personal, borrowed, or company vehicle:

Get a ride from a friend or family member :

Taxi / Uber / Lyft / Car Share:

Walk :

Would not have made the trip at all :

Other (please specify) :

Total :

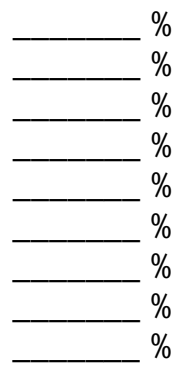




\section{Sample User Survey - Chicago}

In the previous question, you indicated that you would not have made certain trips at all without bike share - for what purposes did you make these trips. Check all that apply.

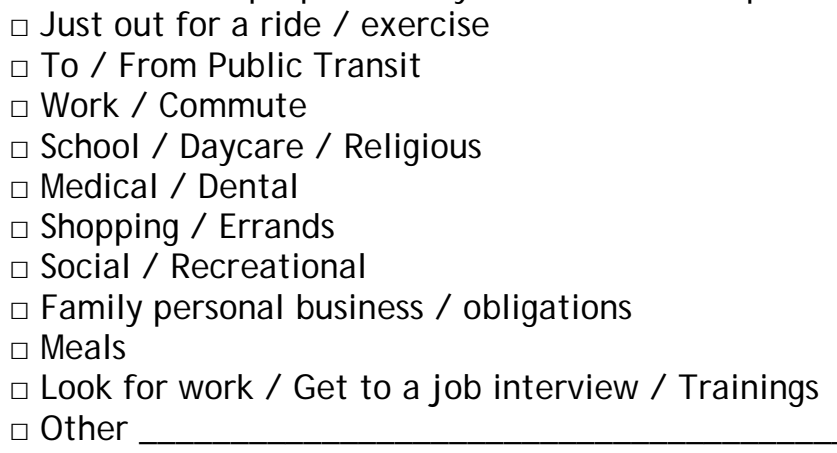

Thinking about the times you have used bike share, which of the following are reasons that you chose to use it? Check all that apply.

$\square$ Too far to walk

$\square$ Going to locations not well served by public transit

$\square$ Travelling at time when public transit is not running (or not running frequently)

$\square$ Don't have access to a car

$\square$ Don't like to drive

$\square$ Parking is limited / expensive

$\square$ Too much traffic

$\square$ Friends wanted to bicycle

$\square$ Wanted to get exercise

$\square$ Bicycle is faster / easier to that destination

$\square$ Bicycle is cheaper than other alternatives

$\square$ Nice weather / wanted to be outside / just like biking

$\square$ Needed / wanted one-way trip

$\square$ J ust wanted to try biking for certain trips

$\square$ Bike share stations near home / work / school

$\square$ To help the environment

$\square$ Don't have to use a bike of my own

$\square$ Don't have to store / access my bike at home

$\square$ Other (please specify) 


\section{Sample User Survey - Chicago}

Thinking about the times you have used bike share, which of the following are reasons that you chose it?

Check all that apply.

Too far to walk

Going to locations not well served by public transit

Travelling at time when public transit is not running (or

not running frequently)

Don't have access to a car

Don't like to drive

Parking is limited / expensive

Too much traffic

Friends wanted to bicycle

Wanted to get exercise

Bicycle is faster / easier to that destination

Bicycle is cheaper than other alternatives

Nice weather / wanted to be outside / just like biking

Needed / wanted one-way trip

J ust wanted to try biking for certain trips

Bike share stations near home / work / school

To help the environment

Don't have to use a bike of my own

Don't have to store / access my bike at home

Other (please specify)

$\begin{array}{cccc}\begin{array}{c}\text { Minor } \\ \text { Reason }\end{array} & \begin{array}{c}\text { Contributing } \\ \text { Reason }\end{array} & \begin{array}{c}\text { Primary } \\ \text { Reason }\end{array} & \begin{array}{c}\text { Not } \\ \text { Sure }\end{array} \\ 0 & 0 & 0 & 0 \\ 0 & 0 & 0 & 0 \\ 0 & 0 & 0 & 0 \\ 0 & 0 & 0 & 0 \\ 0 & 0 & 0 & 0 \\ 0 & 0 & 0 & 0 \\ 0 & 0 & 0 & 0 \\ 0 & 0 & 0 & 0 \\ 0 & 0 & 0 & 0 \\ 0 & 0 & 0 & 0 \\ 0 & 0 & 0 & 0 \\ 0 & 0 & 0 & 0 \\ 0 & 0 & 0 & 0 \\ 0 & 0 & 0 & 0 \\ 0 & 0 & 0 & 0 \\ 0 & 0 & 0 & 0 \\ 0 & 0 & 0 & 0 \\ 0 & 0 & 0 & 0 \\ 0 & 0 & 0 & 0\end{array}$

As a result of using Divvy, are you spending more or less money on...?

Public transit (fares, passes, etc.)

Driving a personal car (gas, parking, etc.)

Taxi / Uber / Lyft / Car Share

Transportation overall

$\begin{array}{cccccc}\begin{array}{c}\text { Much } \\ \text { More }\end{array} & \text { More } & \begin{array}{c}\text { About the } \\ \text { Same }\end{array} & \text { Less } & \begin{array}{c}\text { Much } \\ \text { Less }\end{array} & \begin{array}{c}\text { Does Not } \\ \text { Apply }\end{array} \\ 0 & 0 & 0 & 0 & 0 & 0 \\ 0 & 0 & 0 & 0 & 0 & 0 \\ 0 & 0 & 0 & 0 & 0 & 0 \\ 0 & 0 & 0 & 0 & 0 & 0\end{array}$

On a WEEKLY basis, about how much money do you think Divvy saves you on your travel compared to what you were spending before?
$\bigcirc \$ 0$
$0 \$ 1-5$
$0 \$ 6-10$
$0 \$ 11-20$
O $\$ 21$ or more
O Don't know

As a result of my use of Divvy, I have been getting...

O Much more exercise

O More exercise

O About the same exercise as before

O Less exercise

O Much less exercise

O My exercise level has changed since I started using Divvy but not because of Divvy. 


$$
\text { Sample User Survey - Chicago }
$$

As a result of using Divvy, are you spending more or less money on...?

\begin{tabular}{l|cccccc} 
& $\begin{array}{c}\text { Much } \\
\text { More }\end{array}$ & More & $\begin{array}{c}\text { About the } \\
\text { Same }\end{array}$ & $\begin{array}{c}\text { Less } \\
\text { Much } \\
\text { Less }\end{array}$ & $\begin{array}{c}\text { Does Not } \\
\text { Apply }\end{array}$ \\
\hline Exercise Classes or Gym membership & 0 & 0 & 0 & 0 & 0 & 0 \\
Health care & 0 & 0 & 0 & 0 & 0 & 0 \\
Other & 0 & 0 & 0 & 0 & 0 & 0
\end{tabular}

\section{Reasons for not using Divvy - Chicago's bike share system more}

Which of the following are things that keep you from using Divvy more. Check all that apply, even if they are small barriers.

口 I worry that I'll have to pay for the bike if anything happens to it

$\square$ Divvy bikes won't adjust to fit me properly

$\square$ I don't have a smart phone

口 I don't know where other stations are to drop off a bike

$\square$ I don't want to be seen on a Divvy bike

$\square$ Checking out and returning Divvy bikes is too complicated

- I can't use Divvy with my child(ren)

- I just prefer to ride my own bike

$\square$ Too hard to carry things

$\square$ Other:

$\square$ None of these - There are no barriers that prevent me from using Divvy more

When considering whether you might use Divvy more, how much of a barrier are the following for you? (only display selected items from above list)

I worry that I'Il have to pay for the bike if anything happens to it

Divvy bikes won't adjust to fit me properly

I don't have a smart phone

I don't know where other stations are to drop off a bike

I don't want to be seen on a Divvy bike

Checking out and returning Divvy bikes is too complicated

I can't use Divvy with my child(ren)

I just prefer to ride my own bike

Too hard to carry things

Other:

None of these - There are no barriers that prevent me from using

Divvy more

$\begin{array}{cccc}\begin{array}{c}\text { Not a } \\ \text { barrier }\end{array} & \begin{array}{c}\text { Small } \\ \text { barrier }\end{array} & \begin{array}{c}\text { Big } \\ \text { barrier }\end{array} & \begin{array}{c}\text { Not } \\ \text { Sure }\end{array} \\ 0 & 0 & 0 & 0 \\ 0 & 0 & 0 & 0 \\ 0 & 0 & 0 & 0 \\ 0 & 0 & 0 & 0 \\ 0 & 0 & 0 & 0 \\ 0 & 0 & 0 & 0 \\ 0 & 0 & 0 & 0 \\ 0 & 0 & 0 & 0 \\ 0 & 0 & 0 & 0 \\ 0 & 0 & 0 & 0 \\ 0 & 0 & 0 & 0\end{array}$

Tell us about the most important barrier keeping you from using Divvy more? [open text response] 


\section{Sample User Survey - Chicago}

The following questions are about bicycling in general (not specifically bike share)

Whether or not you ride a bicycle, do you agree or disagree with the following statements about bicycling:

\begin{tabular}{l|l} 
Strongly Disagree Agree Strongly Does Not \\
Disagree
\end{tabular}

I often see people like me riding bikes in my neighborhood

I would like to ride a bicycle (for transportation) more than I currently do

There are better ways for me to get around than by biking

Riding a bike makes me (would make me) more independent in getting around

Riding a bike helps me (or would help me) spend less on transportation

Riding a bike is (or would be) a good way for me to spend time with friends or family

I'm bicycling more now than I did a year ago

I plan to ride a bicycle more often in the next year

There is a bike shop that is convenient for me to go to

$\begin{array}{ll}0 & 0 \\ 0 & 0 \\ 0 & 0 \\ 0 & 0 \\ 0 & 0 \\ 0 & 0 \\ 0 & 0 \\ 0 & 0 \\ 0 & 0\end{array}$

\section{About riding a bicycle}

For each of the following questions, adjust each of the sliders to best describe you when riding a personal bike (I.e. not a bike share bike).

How fast you ride: Do you usually ride slow, fast, or somewhere in between? [scale from 1 to 10]

How you ride: In choosing how and where to ride, are you generally cautious, aggressive, or somewhere in between? [scale from 1 to 10]

When riding on streets with cars and other traffic: Do you generally feel comfortable, uncomfortable, or somewhere in between? [scale from 1 to 10]

Why you ride: do you usually choose to ride for recreation/ exercise or to get somewhere, or a mix of the two? [scale from 1 to 10]

When riding a Divvy bike, do you ride the same or differently than when riding a personal bike (in terms of the previous questions about fast/ slow, cautious/ aggressive, comfortable, ride purpose)?

$O$ The same as when you ride a personal bike

O Differently than when you ride a personal bike

[Repeat scale questions if differently is selected] 


\section{Sample User Survey - Chicago}

Whether or not you currently ride a bicycle, how comfortable would you be bicycling in each of the following places...?

\begin{tabular}{|c|c|c|c|c|c|}
\hline & $\begin{array}{c}\text { Very } \\
\text { Comfortable }\end{array}$ & $\begin{array}{l}\text { Somewhat } \\
\text { Comfortable }\end{array}$ & $\begin{array}{c}\text { Somewhat } \\
\text { Uncomfortable }\end{array}$ & $\begin{array}{c}\text { Very } \\
\text { Uncomfortable }\end{array}$ & $\begin{array}{l}\text { Don't } \\
\text { Know }\end{array}$ \\
\hline $\begin{array}{l}\text { A path or trail separate from the } \\
\text { street }\end{array}$ & O & O & O & 0 & $\mathrm{O}$ \\
\hline A quiet residential side street & O & O & O & 0 & O \\
\hline $\begin{array}{l}\text { A quiet residential side street that } \\
\text { also had bicycle route markings, wide } \\
\text { speed humps, and other things to } \\
\text { discourage and slow down car traffic }\end{array}$ & O & O & O & 0 & O \\
\hline $\begin{array}{l}\text { A busy street or avenue WITH a } \\
\text { striped bike lane }\end{array}$ & O & O & O & O & O \\
\hline $\begin{array}{l}\text { A busy street or avenue WITHOUT a } \\
\text { striped bike lane }\end{array}$ & O & O & O & O & O \\
\hline
\end{tabular}

\section{Reasons for not bicycling}

Which of the following things keep you from riding a bike (or from biking more)? Check all that apply, even if they are small barriers.

$\square$ The places that I need to go are too far away to reach on a bike

- I don't know how to get where I need to go by bike

$\square$ Traffic makes riding a bike in my neighborhood feel dangerous

$\square \mathrm{I}$ am too old to ride a bike

$\square$ I am too out of shape to ride a bike

$\square$ Biking might aggravate my personal health issues

$\square$ Carrying things on a bike is too difficult

$\square$ Riding a bike with my kids is a hassle

$\square$ Something could go wrong with a bike (such as a flat tire)

$\square$ My friends and family wouldn't want me to ride a bike

$\square$ Riding a bike is not viewed as a cool activity by my friends

$\square$ People might think that I can't afford a car

$\square$ Riding a bike could make me a target for police attention

$\square$ Riding a bike could cause me to be harassed or a victim of crime

$\square$ Riding a bike could mess up my hair or appearance

$\square$ The clothes I wear are not appropriate for biking

$\square$ Riding a bike could make me sweaty

$\square$ Other:

$\square$ None of these - nothing keeps me from riding a bike (or from biking more) 


\section{Sample User Survey - Chicago}

When considering the things that keep you from riding a bike (or from biking more), how much of a barrier are each of them? (only display selected items from above list)

The places that I need to go are too far away to reach on a bike Not a Small Big Not barrier barrier barrier sure

I don't know how to get where I need to go by bike

Traffic makes riding a bike in my neighborhood feel dangerous

I am too old to ride a bike

I am too out of shape to ride a bike

Biking might aggravate my personal health issues

Carrying things on a bike is too difficult

Riding a bike with my kids is a hassle

Something could go wrong with a bike (such as a flat tire)

My friends and family wouldn't want me to ride a bike

Riding a bike is not viewed as a cool activity by my friends

People might think that I can't afford a car

Riding a bike could make me a target for police attention

Riding a bike could cause me to be harassed or a victim of crime

Riding a bike could mess up my hair or appearance

The clothes I wear are not appropriate for biking

Riding a bike could make me sweaty

Other:

None of these - nothing keeps me from riding a bike (or from biking more)

$\begin{array}{llll}0 & 0 & 0 & 0 \\ 0 & 0 & 0 & 0 \\ 0 & 0 & 0 & 0 \\ 0 & 0 & 0 & 0 \\ 0 & 0 & 0 & 0 \\ 0 & 0 & 0 & 0 \\ 0 & 0 & 0 & 0 \\ 0 & 0 & 0 & 0 \\ 0 & 0 & 0 & 0 \\ 0 & 0 & 0 & 0 \\ 0 & 0 & 0 & 0 \\ 0 & 0 & 0 & 0 \\ 0 & 0 & 0 & 0 \\ 0 & 0 & 0 & 0 \\ 0 & 0 & 0 & 0 \\ 0 & 0 & 0 & 0 \\ 0 & 0 & 0 & 0 \\ 0 & 0 & 0 & 0 \\ 0 & 0 & 0 & 0\end{array}$

\section{Please answer a few questions about you and your household. Then you're all done!}

In general, would you say that your health is...?
O Excellent
O Very good
O Good
O Fair
O Poor

In general, how physically active are you?

O Not active at all

O Not very active

O Somewhat active

$O$ Very active

O Don't know / not sure 
Do you currently have a...?

\section{Check all that apply.}

$\square$ Driver's license

$\square$ Transit Pass

$\square$ Working bicycle

$\square$ Car available for use

$\checkmark$ Carshare membership (e.g. ZipCar, Car2Go)

$\square$ Smart phone

$\square$ Credit card

$\square$ Debit card

$\square$ Reliable internet access

$\square$ None of these

How old are you? In years

Are you:
O Male
O Female
$\mathrm{O}$

Do you currently work ...

O 1 job

O 2 or more jobs

O Not employed

If employed, how many hours per week?

O 35 hours or more

O Less than 35 hours

Are you currently a student?
O Full-time
O Part-time
O Not a student

What is the highest level of school you have completed?

O Less than High School

O High School Diploma / GED

O Some College, No Degree

O Associate's Degree

O Bachelor's Degree

O Graduate or Professional degree

Do you consider yourself:

\section{Check all that apply.}

$\square$ Hispanic, Latino, or Spanish Origin

$\square$ American Indian or Alaska Native

$\square$ Asian

$\square$ Black or African American

$\square$ White

$\square$ Prefer not to say

$\square$ Other

Do you rent or own your home?
O Rent
O Own
O Other 


\section{Sample User Survey - Chicago}

If renting, are you receiving a housing subsidy or discount?

(Such as Section 8, public housing, or subsidized housing [e.g. paying a set percentage of your income for rent])

O Yes

O No

What is your home zip code?

For our analysis about how you get around, it would be helpful to know approximately where you live and work.

Please indicate two streets that cross near your HOME location

Street 1 St

reet 2

Please indicate two streets that cross near your WORK location as well as the city in which you WORK Street 1 Street 2 City

How long have you lived... .

At your current address (\# of years):

In your current neighborhood (\# of years)

Including yourself, how many people are there in your household?

\# of Adults (including yourself)

\# of Children (enter 0 if none)

\# of total people living in your household who are related to you (not including yourself)

What is your annual household income?

$\mathrm{O}$ Less than $\$ 15,000$

O $\$ 15,000-\$ 24,999$

O $\$ 25,000-\$ 34,999$

O $\$ 35,000-\$ 49,999$

O $\$ 50,000-\$ 59,999$

O $\$ 60,000-\$ 74,999$

O $\$ 75,000-\$ 99,999$

O $\$ 100,000-\$ 124,999$

O $\$ 125,000-\$ 149,999$

O $\$ 150,000$ or more

Which one of the following four statements best describes your ability to get along on your household income?

O I / we can't make ends meet

O I / we have just enough, no more

O I / we have enough, with a little extra sometimes

O I/ we always have money left over

Is there anything else you would like to add or explain? [open text response]

Thanks for completing the survey! If you have any questions about the study, please contact us at streets@pdx.edu or 503-725-2875. 